JNoP JURNAL INOVASI PEMBELAJARAN

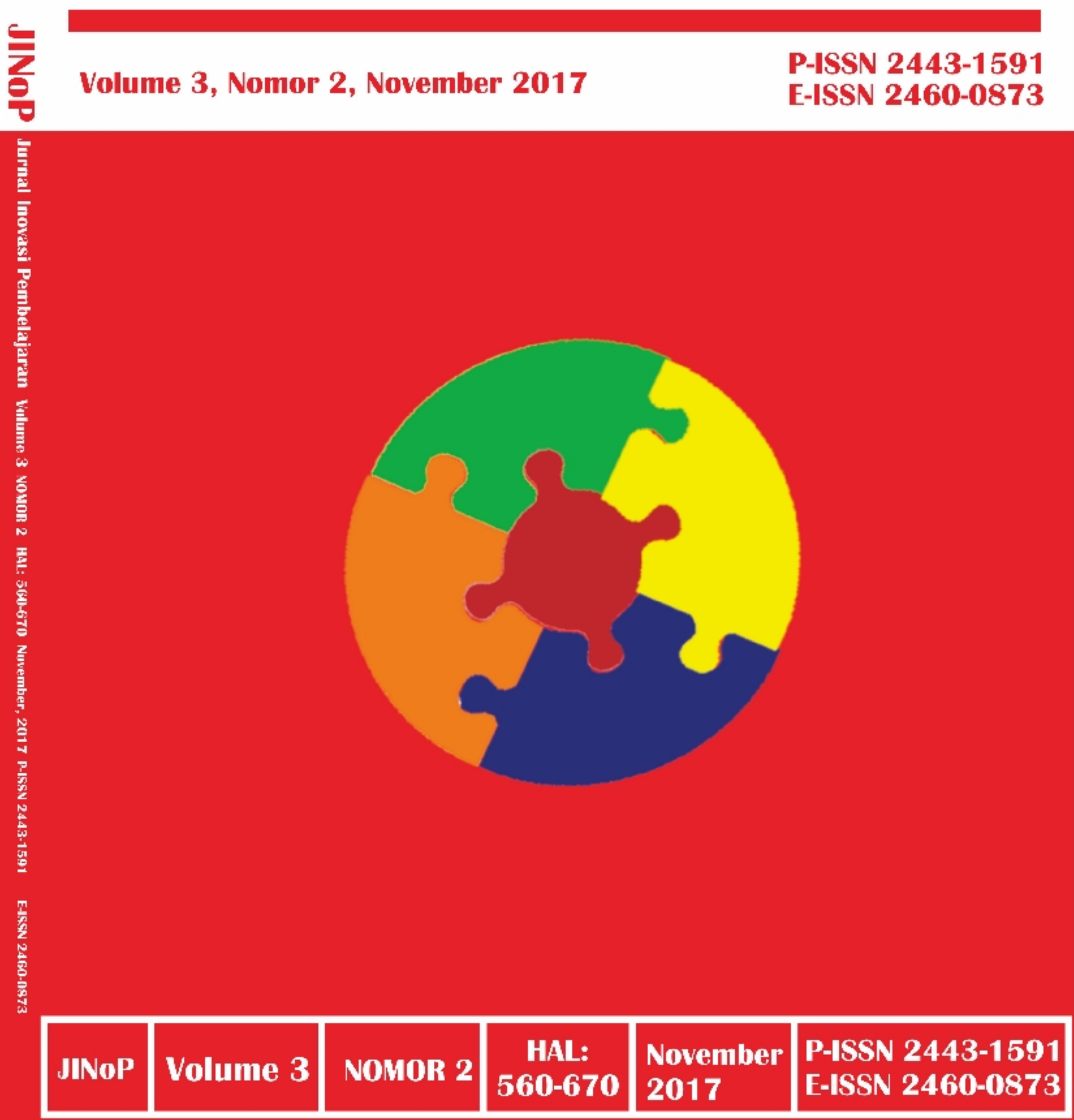




\section{JINOP \\ Jurnal Inovasi Pembelajaran \\ Volume 3, Nomor 2, November 2017}

Diterbitkan dua kali setahun pada bulan Mei dan November oleh Fakultas Keguruan dan Ilmu Pendidikan Universitas Muhammadiyah Malang dalam satu volume ada 2 nomor. Berisi tulisan ilmiah hasil penelitian tentang inovasi pembelajaran mulai dari pendidikan dasar sampai perguruan tinggi. Untuk Jurnal Online bisa diakses dilaman : http://ejournal.umm.ac.id/index.php/jinop/

\section{Ketua Penyunting}

Dr. Sugiarti, M.Si.

\section{Wakil Ketua Penyunting}

Rinjani Bonavidi, Ph.D.

\section{Penyunting Pelaksana}

Dr. Baiduri, M.Si.

Dr. M. Syahri, M.Si.

Dra. Sri Wahyuni, M.Kes.

Adityo, M.A.

\section{Mitra Bestari}

Dr. Somakim, M.Pd. (UNSRI)

Dr. Ibrohim, M.Si. (UM)

Dr. Kokom Komalasari, M.Pd. (UPI)

Dr. Waras Kamdi, M.Pd. (UM)

Prof. Dr. Endang Widi Winarni (UNIB)

\section{Pelaksana Administrasi}

Nur Adeputra, S.Pd.

Alamat Penyunting dan Tata Usaha

Kantor Jurnal Inovasi Pembelajaran (JINOP) Ruang 614

Jl. Raya Tlogomas 246 Malang 65144, Telp. (0341) 464318; Faksimile (0341) 460782

Pos-cl : jinopfkip(a)gmail.com dan jinoptkip(a)umm.ac.id

$\overline{\text { Penyunting menerima sumbangan tulisan dari guru dan dosen yang belum pernah dimuat }}$ dalam media lain. Naskah ditulis dalam kertas A4 spasi satu antara 10-15 halaman, sesuai dengan format yang tercantum pada halaman belakang ("Petunjuk Penulisan artikel JINoP"). Penulis akan mendapatkan nomor bukti penerbitan sebanyak 2 eksemplar.

Dicetak di Percetakan UMM Press. Isi di luar tanggungjawab Percetakan 


\section{JINoP (Jurnal Inovasi Pembelajaran) \\ P-ISSN : 2443-1591 \\ E-ISSN : 2460-0873 \\ Volume 3, Nomor 2, November 2017}

\section{DAFTAR ISI}

Pemanfaatan Geometer's Sketchpad dalam Melukis Fungsi Trigonometri

$560-566$

Agung Deddiliawan Ismail dkk

Peningkatan Keterampilan Berbicara Dalam Bermain Drama Melalui

$567-575$

ModelPembelajaran Kooperatif Tipe Inside-Outside Circle.

\section{Candra Dewi}

Peningkatan Ketahanan Pribadi Siswa dalam Pelajaran Matematika melalui

Pembelajaran Kooperatif STAD Siswa Kelas XI TKR 2 SMK Negeri I

Singosari

Djulikah

An Interpretive Study Of The Communication Needs of English

Department Students at University Of Muhammadiyah Malang

588-598

Dwi Poedjiastutie dkk

Penerapan Model Pembelajaran Make A Match Untuk Meningkatkan

Hasil Belajar Matematika Tentang Pembagian Pada Siswa Kelas II SD

Muhammadiyah 4 Batu

\section{Mariani}

Implementation Of 2015 Mentoring Program In English Department Of

University of Muhammadiyah Malang

Nina Inayati dkk

Praktik Kolaboratif Pada Pembelajaran Biologi Materi Reproduksi Berbasis

Lesson Study di SMA Negeri 1 Sumberpucung

Purwatiningsih dkk

Peningkatan Hasil Belajar Bilangan Berpangkat dengan Model Problem Posing Pada Siswa Kelas IX SMP Negeri 4 Batu

Sudiyono 
Peningkatan Motivasi dan Hasil Belajar IPA melalui Model Pembelajaran

$649-658$

Think Pair and Share dengan Pemberian Guided Questions System

pada Siswa Kelas VIII SMP Negeri 24 Malang

Yuliati

Peningkatan Minat Kewirausahaan Siswa SMP dengan Pendekatan

$659-670$

Scientific Sell

Zakki Fitroni 



\title{
PEMANFAATAN GEOMETER'S SKETCHPAD DALAM MELUKIS FUNGSI TRIGONOMETRI
}

\author{
Agung Deddiliawan Ismail, Rizal Dian Azmi \\ FKIP Universitas Muhammadiyah Malang \\ Email: deddiliawan@gmail.com
}

\begin{abstract}
ABSTRAK
Trigonometri merupakan salah satu cabang ilmu Matematika yang banyak digunakan di berbagai bidang. Materi trigonometri kadang menyulitkan bagi para pendidik saat mengajarkan kepada mahasiswa. Ini dikarenakan materi - materi dalam trigonometri memerlukan suatu gambaran simulasi untuk mengajarkan konsep trigonometri kepada peserta didik. Untuk menggambarkan simulasi dari fungsi trigonometri tersebut diperlukan suatu media sebagai tuntunan mahasiswa, dimana media yang tepat untuk itu adalah Geometer's Sketchpad. Pendekatan Penelitian yang digunakan adalah penelitian kuantitatif dengaj jenis deskriptif. Pair Sample T-test digunakan untuk menentukan adanya peningkatan keterampilan melukis mahasiswa. Berdasarkan hasil penelitian yang telah dilakukan maka dapat disimpulkan bahwa pembelajaran dengan memanfaatkan Geometer's Sketchpad dapat membantu mahasiswa dalam melukis fungsi Trigonometri. Terlihat dari nilai probabilitas $0,000<0,05$ yang menyatakan bahwa adanya peningkatan keterampilan mahasiswa dalam melukis grafik fungsi Trigonometri.
\end{abstract}

Kata kunci: Trigonometri, Geometer's Sketchpad.

\begin{abstract}
Trigonometry is a part of the Mathematics which is used in variety of science area. Trigonometry sometimes becomes a difficult material for teachers to teach due to the materials in trigonometry requires an illustration of the simulation to teach the basic concepts of trigonometry to students. To illustrate the simulation of the trigonometric functions, it needs a media as the guidance of students, in which an appropriate media for the guidance is Geometer's Sketchpad. Based on the research that has been conducted, it can be concluded that learning by utilizing Geometer's Sketchpad can assist the students in drawing Trigonometry functions. The result is seen from a probability value of $0.000<0.05$, which states that an increase in students' skills in drawing graphs of Trigonometry functions.
\end{abstract}

Keywords: Trigonometry, Geometer's Sketchpad.

\section{PENDAHULUAN}

Trigonometri merupakan salah satu cabang ilmu Matematika. Sejarah mengatakan bahwa Trigonometri lahir karena adanya ilmu Geometri dan Astronomi. Seiring dengan perkembangan pengetahuan Trigonometri berdiri sendiri menjadi salah satu ilmu penting dalam pengetahuan. Manfaat trigonometri digunakan dalam semua bidang termasuk bidang pertahanan militer, kesehatan, bahkan sampai pada infrastruktur. Materi trigonometri adalah kadang menyulitkan bagi para pendidiksaat mengajarkan kepada peserta didik, daripada mengajarkan materi matematika lainnya. Ini disebabkan oleh karena materi - materi dalam trigonometri memerlukan suatu gambaran atau simulasi untuk membuat peserta didik mengerti dengan konsep pada trigonometri itu sendiri. 
Berdasarkan hasil analisis tugas mahasiswa semester 1 kelas B pada materi melukis grafik fungsi $\sin \theta \cos \theta$ dan dari 42 mahasiswa 28 diantaranya masih mengalami kesalahan dalam menggambar fungsi trigonometri berakibat hasil tes di bawah KKM matakuliah trigonometri yaitu 65. Terlihat bahwa mahasiswa masih kesulitan dalam melukis grafik fumgsi trigonometri. Secara konsep mahasiswa dapat memahami, terlihat bahwa mahasiswa dapat menyelesaikan masalah fungsi trigonometri dengan benar. Tetapi untuk memvisualisasikan fungsi trigonometri menjadi suatu grafik masih kesulitan.

Berdasarkan permasalahan tersebut dibutuhkan suatu alat atau media yang mampu membimbing mahasiswa dalam melukis grafik fungsi trigonometri. Sehingga dapat memudahkan mahasiswa untuk mengenali bentuk dan lukisan grafik fungsi trigonometri. Media yang dapat digunakan sebagai guide atau penuntun mahasiswa dalam melukis adalah Geometer's Sketchpad. Menurut Sugiarto (2009), pemanfaatan media yang dilakukan secara benar akan memberikan kemudahan bagi peserta didik untuk membangun sendiri pengetahuan yang sedang dipelajarinya. Pengunaan sumber multimedia yang menunjang dari aspek pembelajaran terpadu memberikan manfaat dalam pengajaran dan penilaian matematika (Herrington, 1998). Sejalan dengan itu Meng (2011) mengemukakan bahwa software Geometer's Sketchpad dapat menjadi inovatif untuk meningkatkan pembelajaran matematika (Norazah dkk, 2008). Sejalan dengan pendapat di atas Rahmawati (2009) juga menjelaskan bahwa Geometer's Sketchpad sangan membatu siswa dalam bidang trigonometri.
Berdasarkan latar belakang yang terjadi pada mahasiswa semester 1 kelas B pada matakuliah trigonometri maka rumusan masalah yang akan digunakan adalah bagaimana pemanfaatan Geometer's Sketchpad pada materi grafik fungsi trigonometri dan hasil kerja mahasiswa setelah menggunakan Geometer's Sketchpad pada materi grafik fungsi trigonometri. Sehingga tujuan penelitian adalah mendeskripsikan penggunaan Geometer's Sketchpad pada materi grafik fungsi trigonometri dan hasil kerja mahasiswa setelah menggunakan Geometri's Sketpad pada materi grafik fungsi trigonometri.

\section{METODE}

Objek penelitian yang digunakan pada penelitian ini adalah mahasiswa UMM Prodi Pendidikan Matematika semester satu kelas B. Pendekatan yang digunakan pada penelitian ini adalah pendekatan kualitatif dan kuantitatif. Arikunto (2006) menjelaskan bahwa penggunaan pendekatan kualitatif ini didasarkan pada tujuan penelitian. Tujuan dalam penelitian ini adalah akan menjelaskan tentang keterampilan mahasiswa dalam melukis fungsi trigonometri setelah menggunakan Geometer's Sketchpad. Sedangkan pendekatan kuantitatif akan digunakan sebagai pendukung data kualiatatif. Jenis yang digunakan adalah penelitian deskriptif. Dimana penelitian yang dilaksanakan akan dijelaskan berdasarkan apa yang terjadi pada proses penelitian. Teknik analisis data kuantitatif menggunakan uji Pair Sample t-Test sedangkan untuk teknik data kualitatif menggunakan teknik data menurut Miles dan Huberman (2014) yang terdiri atas pengumpulan data, reduksi data dan mengampilan kesimpulan. 


\section{HASIL DAN PEMBAHASAN}

Mata kuliah Trigonometri sangat difokuskan pada bagian visualisasi grafik dari persamaan trigonometri yang diberikan. Hal ini mengharuskan mahasiswa untuk mengetahui visualisasi grafik yang benar dari berbagai persamaan. Berdasarhan hasil observasi awal didapatkan temuan yaitu masih ada mahasiswa yang masih kesulitan dalam menggambar kurva fungsi trigonometri. Mata kuliah Trigonometri sangat difokuskan pada bagian visualisasi grafik dari persamaan trigonometri yang diberikan. Hal ini mengharuskan mahasiswa untuk mengetahui visualisasi grafik yang benar dari berbagai persamaan.Pada pembelajaran kedua, pembelajaran Trigonometri yang mengkhususkan pada penggambaran grafik ini dibantu dengan Geometer's Sketchpad yang dilakukan pada tanggal 8 Desember 2015. Hal ini dilakukan untuk membantu mahasiswa untuk memvisualisasikan dengan benar berbagai fungsi dalam trionometri.

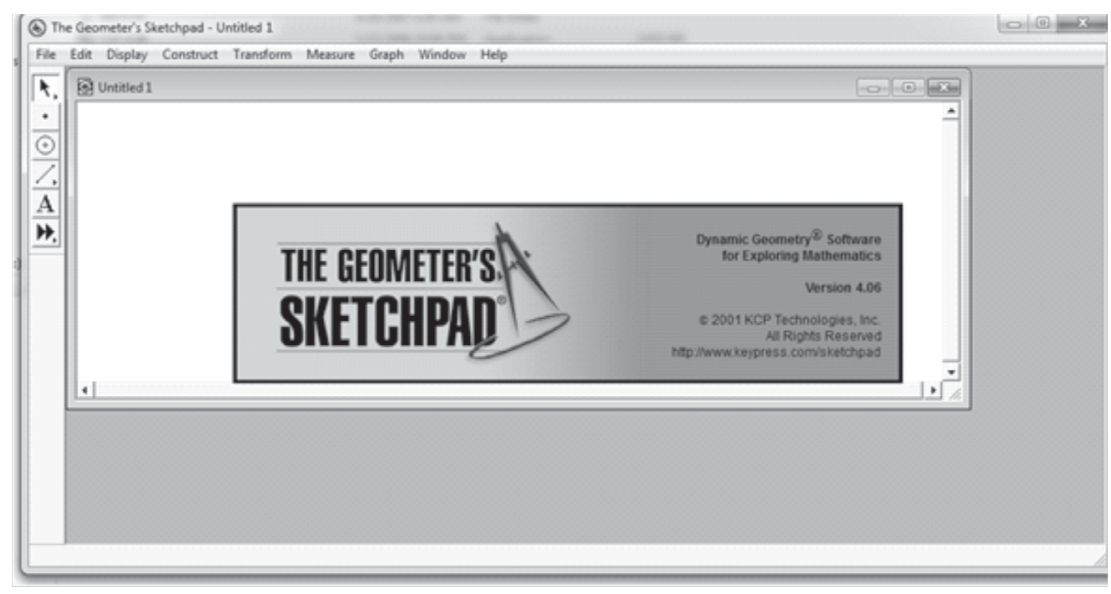

Gambar 1. Tampilan Geometer's Sketchpad

Diawal pembelajaran mahasiswa dikenalkan mengenai menu dasar Geometer's Sketchpad seperti Gambar 1. Kemudian siswa dibimbing untuk menggunakan Geometer's Sketchpad untuk memvisualisasikan fungsi $\mathrm{y}=2 \sin x$ pada interval $[-\pi 4 \pi]$ yang terdapat pada buku latihan Larson (2007) dan Baley \& Sarrell (2003). Dengan menggunakan media Geometer's Sketchpad ini, mahasiswa dapat melihat animasi pergerakan/perubahan grafik trigonometri yang disebabkan oleh perubahan parameter - parameter yang terdapat pada fungsi - fungsi trigonometri tersebut. Setelah mahasiswa mengerti dengan perubahan grafik trigonometri ini, mahasiswa diingatkan kembali dengan konsep awal dari fungsi - fungsi trigonometri.

Setelah mengingat konsep dasar dalam menggambar grafik trigonometri mahasiswa dituntun tahap demi tahap dalam menggambar dengan Media Geometer's Sketchpad. Mahasiswa diajak untuk menggunakan Media Geometer's Sketchpad dengan tujuan agar mahasiswa lebih teliti dalam belajar tentang grafik trigonometri. Langkah pertama yaitu membuka halaman baru dan mengatur halaman dalam bentuk petak atau grid (Gambar 2 dan 3). 


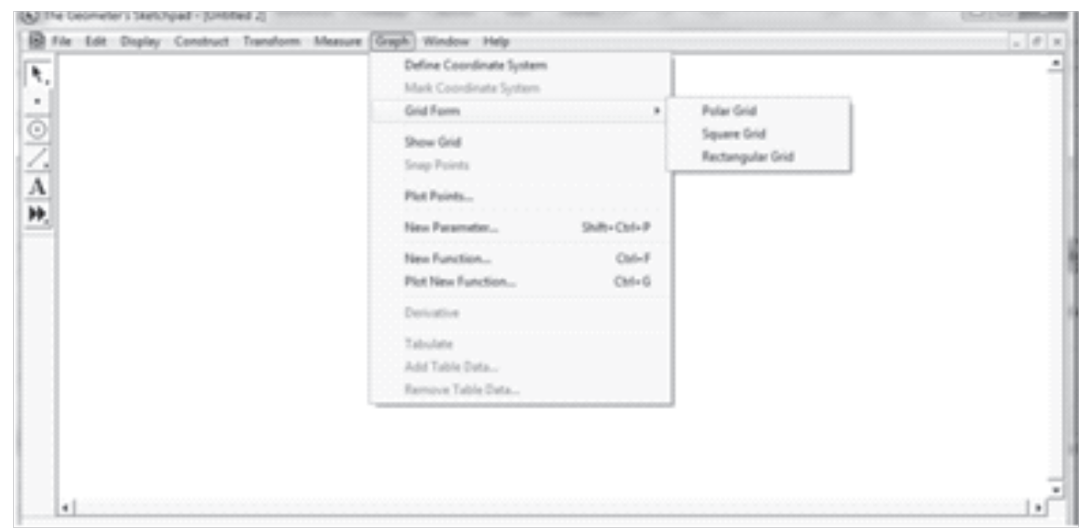

Gambar 2. Mengatur halaman

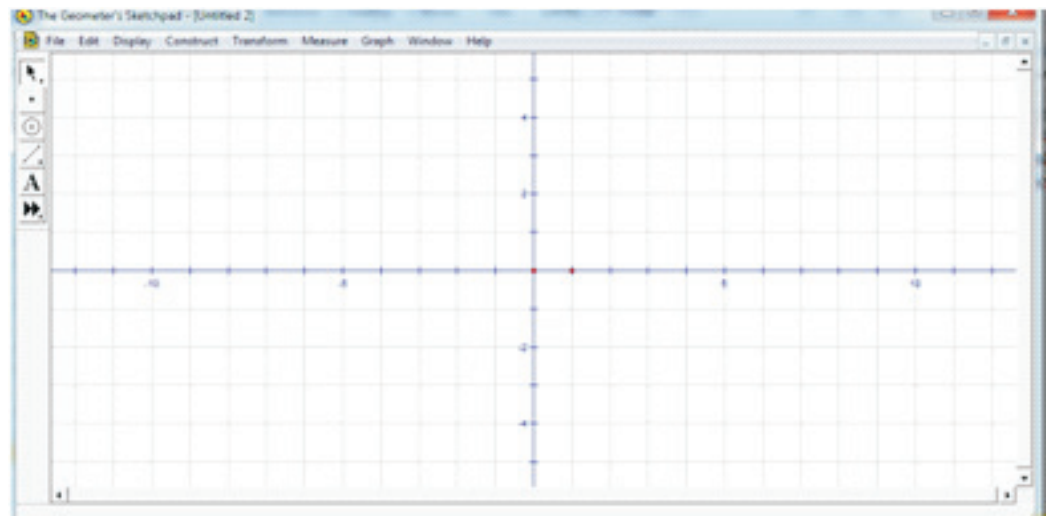

Gambar 3. Halaman Grid/Petak

Sebelum menggambar grafik terlebih New Functions (Gambar 4). Fungsi yang dahulu mahasiswa diajak untuk didefinisikan bisalh lebih dari satu mendefinisikan fungsi yang akan sehingga akan memudahkan jika ingin divisualisasikan dengan cara memilih membandingkan beberap grafik dalam satu menu Grahp dan memilih submenu Plot halaman.

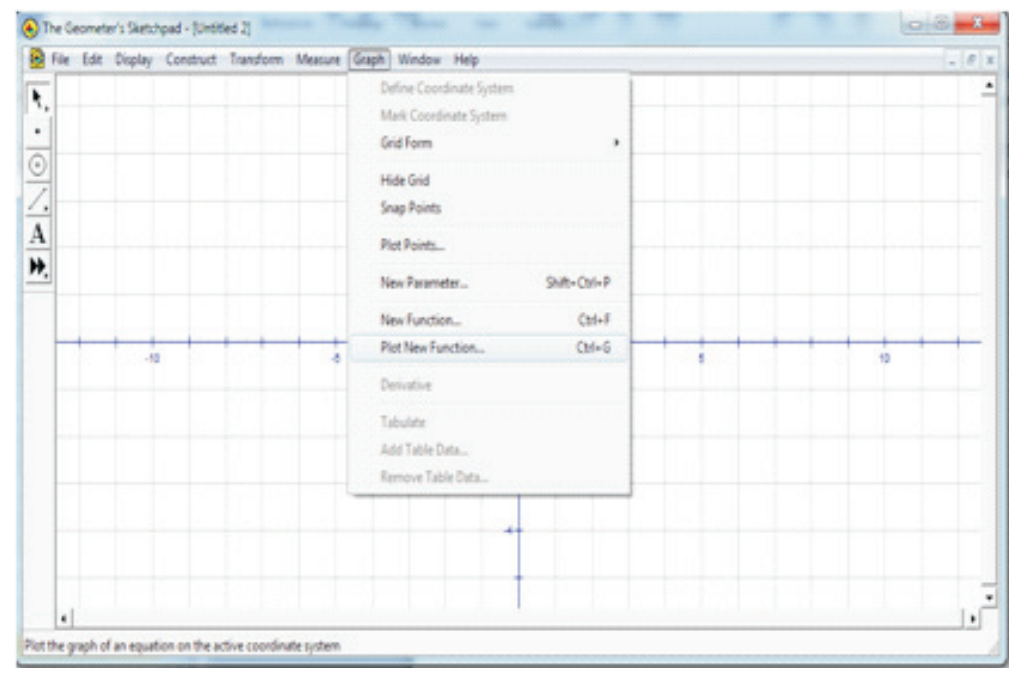

Gambar 4. New Plot Function

Agung Deddiliawan Ismail dan Rizal Dian Azmi, Pemanfaatan Geometer's Sketchpad Dalam Melukis Fungsi Trigonometri 
Langkah selanjutnya adalah dimasukkan fungsi $g(x)=2 \sin x$ dan fungsi pada kolom inputan seperti pada tekan $O K$. Maka akan muncul grafik Gambar 8. Pada kolom tersebut fungsi pada layar seperti Gambar 5.

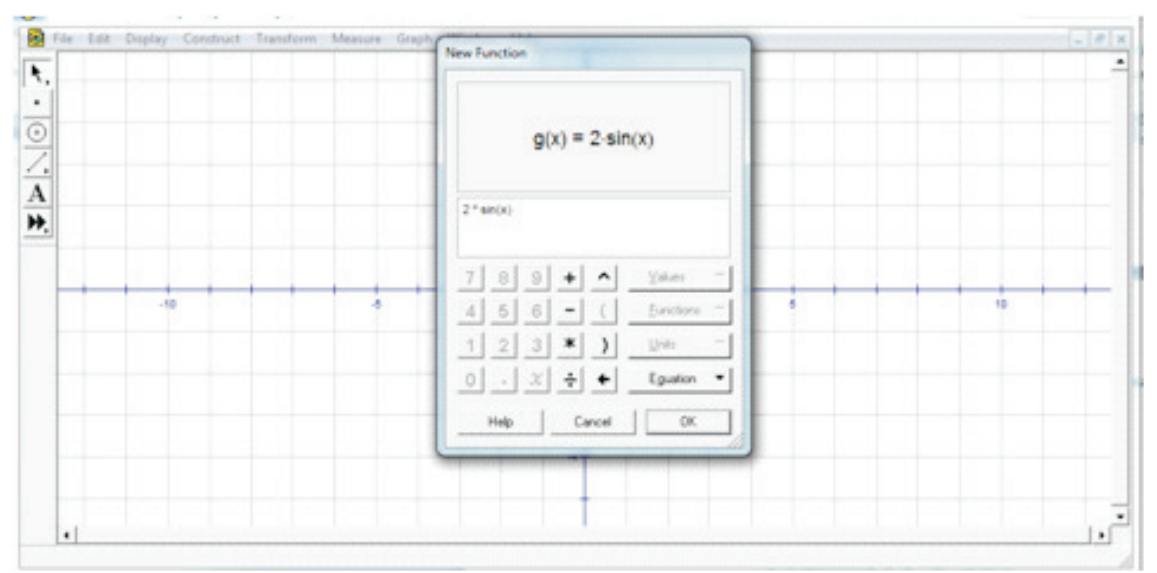

Gambar 5. Input Fungsi Trigonometri

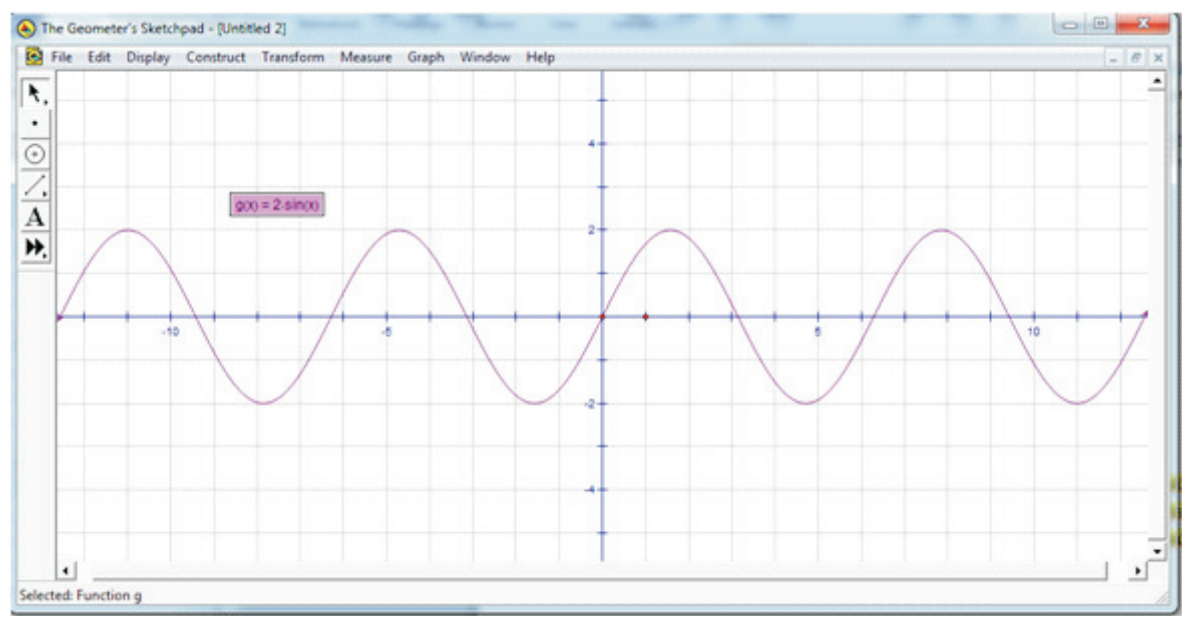

Gambar 6. Grafik Fungsi g $(x)=2 \sin x$

Selanjutnya mahasiswa diajak untuk menentuakn intercepts, maximum pointsdan maximum points (Gambar 6). Mahasiswa diajak bersama-sama dalam menggambar kurva secara manual dari fungsi $\mathrm{g}(x)=2 \sin x$. Fungsi $\mathrm{g}(x)=2$ $\sin x=2 \sin x$ yang artinya bahwa nilai $\mathrm{y}$ adalah dua kali dari dan hasial diskusi disapat titik interceps $(-\pi, 0),(0,0),(\pi, 0)$, $(2 \pi, 0)$ dll. Untuk minimum points adalah sebagai berikut $\left(-\frac{\pi}{2},-2\right),\left(\frac{3 \pi}{2},-2\right),\left(\frac{7 \pi}{2},-2\right)$ dll. Sedangkan untuk maximum points-nya adalah $\left(\frac{\pi}{2}, 2\right),\left(\frac{5 \pi}{2}, 2\right)$ dll.
Setelah mengerti bagaimana cara penggunaan Media Geometer's Sketchpad, mahasiswa diberikan soal latihan dan pada penutup fase pembelajaran kedua ini adalah diberikan post test dengan memberikan tugas untuk menggambar beberapa grafik trigonometri secara manual dengan bantuan Media Geometer's Sketchpad.

Post test yang dilakukan pada setiap pertemuan yang digunakan untuk mengevaluasi hasil pembelajaran yang telah dilakukan. Dari hasil evaluasi yang telah dianalisis dengan sofare SPSS diperoleh 
bahwa rata-rata pada data nilai akhir lebih besar dibandingkan nilai awal yang didapat dari hasil observasi awal dan standar deviasinya juga lebih besar. Hal ini menyimpulkan bahwa nilai akhir memiliki rentang data yang lebih luas serta memiliki rata - rata yang lebih baik dibandingkan dengan nilai awal. Sedangkan dari analisis data yang dilakukandisimpulkan bahwa penggunaan Geometer's Sketchpad mempengaruhi nilai mahasiswa. Sehingga dari dua kesimpulan tersebut dapat diketahui bahwa pembelajaran menggunakan Geometer's Sketchpad dapat meningkatkan hasil belajar mahasiswa untuk kuliah Trigonometri. Berdasarkan hasil analisis hasil evaluasi didapat nilai statistic sebagai berikut.

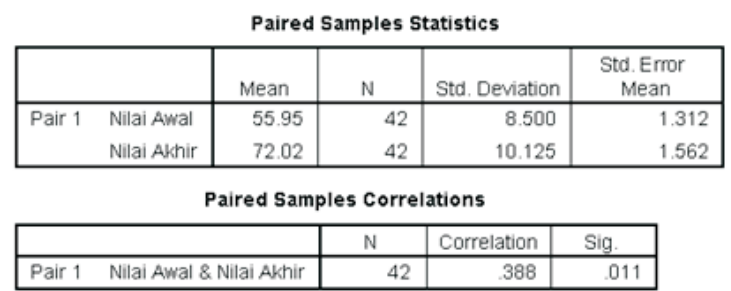

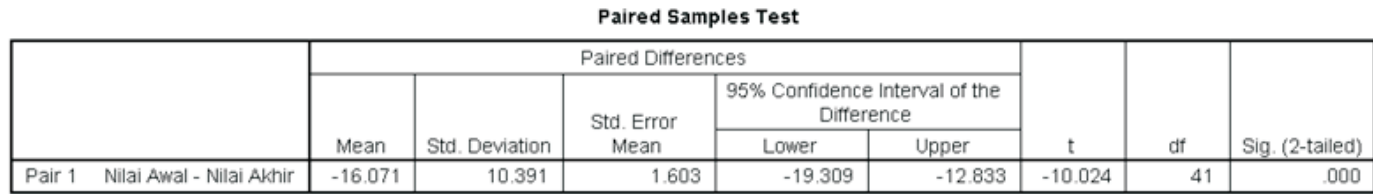

\section{Hipotesis}

Ho : Kedua rata-rata adalah identik (ratarata nilai sebelum dan setelah diberlakukannya pembelajaran dengan Geometer's Sketchpad adalah sama).

H1 : Kedua rata-rata tidak identik (ratarata nilai sebelum dan setelah diberlakukannya pembelajaran dengan Geometer's Sketchpad adalah berbeda).

Karena nilai probabilitas $0,000<0,05$ maka Ho ditolak (H1 diterima), dengan kesimpulan yang sama dengan point a bahwa penggunaan Geometer's Sketchpad mempengaruhi nilai mahasiswa pada mata kuliah Trigonometri.

Dari tabel paired samples statistic pada Gambar 2. Diperoleh bahwa rata-rata pada data nilai akhir (nilai setelah penggunaan Geometer's sketchpad) lebih besar dibandingkan nilai awal (nilai sebelum penggunaan Geometer's Sketchpad) dan standar deviasinya juga lebih besar. Hal ini menyimpulkan bahwa nilai akhir memiliki rentang data yang lebih luas serta memiliki rata - rata yang lebih baik dibandingkan dengan nilai awal. Sedangkan dari analisis adan b disimpulkan bahwa penggunaan Geometer's Sketchpad mempengaruhi nilai mahasiswa. Sehingga dari dua kesimpulan tersebut dapat diketahui bahwa pembelajaran menggunakan Geometer's Sketchpad dapat meningkatkan hasil belajar mahasiswa untuk kuliah Trigonometri.

\section{SIMPULAN}

Berdasarkan hasil penelitian yang telah dilakukan maka dapat disimpulkan bahwa pembelajaran dengan memanfaatkan Geometer's Sketchpad dapat membantu mahasiswa dalam melukis fungsi Trigonometri. Terlihat dari nilai probabilitas $0,000<0,05$ yang menyatakan bahwa adanya peningkatan keterampilan mahasiswa dalam menggambar grafik fungsi Trigonometri. 


\section{DAFTAR PUSTAKA}

Arikunto, S. 2006. Dasar-dasar Evaluasi Pendidikan. Jakarta : Bumi Aksara.

Baley, John B \& Sarrell, Gary. 2003. Trigonometry Revised Third Edition. USA: The McGraw-Hill Companies, Inc.

Herrington, A, Jan. H, Len. S \& R. Oliver. 1998. Learning to Teach and Assess Mathematics Using Multimedia: A Teacher Development Project. Journal of Mathematics Teacher Education 1: 89-112.

Larson, Ron \& Hostetler, Robert. 2007. Trigonometry Seventh Edition. USA: Brooks/Cole

Meng, C. C. \& L. C. Sam. 2011. Encouraging the Innovative Use of Geometer?s Sketchpad through Lesson Study. Journal of Mathematics Teacher Education Vol.2, No.3, 236-243.

Miles dan Huberman. 2014. Qualitative Data Analysis A Methods Sourcebook Edition 3. Los Angels: SAGE.

Norazah, N, E. Zakaria, M. A. Embi \& R. M. Yassin. 2008. Pedagogical Usability of the Geometer?s Sketchpad (GSP) Digital Module in the Mathematics Teaching. Proceedings of the $7^{\text {th }}$ WSEAS International Conference on EDUCATION and EDUCATIONAL TECHNOLOGY : 240-245.

Rahmawati, D. 2009. Penerapan Metode Pembelajaran Penemuan Berbantuan Software GSP pada Materi Teorema Pythagoras di Kelas VIII Billingual SMP Al-Azhar Menganti Gresik. Surabaya : Universitas Negeri Surabaya.

Sugiarto. 2009. Workshop Pendidikan Matematika 1. Semarang: Jurusan Matematika FMIPA UNNES. 


\title{
PENINGKATAN KETERAMPILAN BERBICARA DALAM BERMAIN DRAMA MELALUI MODEL PEMBELAJARAN KOOPERATIF TIPE INSIDE OUTSIDE CIRCLE
}

\author{
Candra Dewi \\ Universitas PGRI Madiun \\ Email: candra_cincun@yahoo.com
}

\begin{abstract}
ABSTRAK
Tujuan penelitian ini adalah untuk meningkatkan kemampuan berbicara melalui penerapan model pembelajaran kooperatif tipe Inside Outside Circle (IOC) pada siswa kelas 4 Sekolah Dasar Negeri Pintu Kecamatan Jenangan Kabupaten Ponorogo. Variabel yang menjadi sasaran perubahan dalam penelitian ini adalah kemampuan berbicara, sedangkan variabel tindakan yang digunakan dalam penelitian ini adalah penerapan model pembelajaran kooperatif tipe Inside Outside Circle (IOC). Bentuk penelitian ini adalah penelitian tindakan kelas sebanyak 2 siklus. Tiap siklus terdiri dari 4 tahapan yaitu perencanaan, pelaksanaan tindakan, observasi dan refleksi. Subyek penelitian adalah siswa kelas 4 Sekolah Dasar Negeri Pintu Kecamatan Jenangan Kabupaten Ponorogo yang berjumlah 20 siswa. Teknik pengumpulan data menggunakan observasi, wawancara, tes dan dokumentasi. Teknik analisis data yang digunakan adalah model analisis interaktif yang mempunyai tiga buah komponen yaitu reduksi data, penyajian data dan penarikan simpulan. Berdasarkan hasil penelitian dapat disimpulkan bahwa ada peningkatan kemampuan berbicara dalam kegiatan bermain peran setelah diadakan tindakan kelas dengan menerapkan model pembelajaran kooperatif tipe Inside Outside Circle (IOC).
\end{abstract}

Kata Kunci : Keterampilan Berbicara, Drama, Inside-Outside Circle

\begin{abstract}
The purpose of this research is to improve the ability to talk through the implementation of cooperative learning model Inside Outside Circle (IOC) in the 4th grade students of State Elementary School District of Jenangan Doors Ponorogo. Variables that were subjected to a change in this study is the ability to speak, while the action variable used in this research is the application of cooperative learning model Inside Outside Circle (IOC). This research is a form of action research as much as 2 cycles. Each cycle consists of four phases: planning, action, observation and reflection. Subjects were students in grade 4 Doors Public Elementary School District of Jenangan Ponorogo totaling 20 students. Data collection technique used observation, interview, test and documentation. Data analysis technique used is an interactive model that has three components: data reduction, data presentation, and drawing conclusions. Based on the results of this study concluded that there is an increased ability to speak after having a class action by implementing cooperative learning model Inside Outside Circle (IOC). It can be shown by the increasing ability of students before and after the action.
\end{abstract}

Keywords :Speaking Skills, Drama, Inside-Outside Circle.

\section{PENDAHULUAN}

Pembelajaran Bahasa Indonesia perlu dilaksanakan secara fungsional dan komunikatif. Siswa tidak hanya belajar tentang pengetahuan bahasa melainkan siswa juga belajar menggunakan bahasa untuk keperluan komunikasi. Komunikasi di sini dimaksudkan sebagai suatu proses pertukaran informasi antar individu melalui suatu sistem yang biasa (lazim) baik dengan 
simbol-simbol, sinyal-sinyal, maupun perilaku atau tindakan. Komunikasi paling tidak melibatkan dua orang atau lebih yang berkomunikasi dengan berbagai macam cara, baik secara verbal maupun nonverbal. Komunikasi verbal dibagi menjadi komunikasi lisan dan komunikasi tulisan. Komunikasi lisan sering terjadi dalam kehidupan manusia, misalnya dialog dalam lingkungan keluarga, dialog pembeli dan penjual, perdebatan, percakapan guru dengan siswa di sekolah dan sebagainya. Untuk berkomunikasi dengan baik, baik dalam bentuk formal maupun non formal, maka diperlukan keterampilan berbahasa, keterampilan berbahasa tersebut harus dikembangkan dalam pembelajaran di sekolah, terutama pembelajaran Bahasa Indonesia di Sekolah Dasar. Tujuan utama berbicara adalah untuk berkomunikasi. Agar dapat menyampaikan pikiran secara efektif, seyogjanya sang pembicara memahami makna segala sesuatu yang ingin dikomunikasikan. Dia harus mampu mengevaluasi efek komunikasinya terhadap (para) pendengarnya dan harus mengetahui prinsip-prinsip yang mendasari segala situasi pembicaraan, baik secara umum maupun perorangan (Tarigan, 2008:16). Pembelajaran berbicara membutuhkan keterampilan dan metode khusus agar keterampilan berbicara tersebut mencapai hasil yang diharapkan. Kenyataaan di lapangan menunjukkan banyak pendidik kurang memahami metode pembelajaran berbicara yang efektif dan efisien, sehingga keterampilan berbicara siswa tidak mencapai hasil seperti yang diharapkan.

Keterampilan berbicara merupakan hal yang sangat penting, karena seseorang yang mahir berbicara akan mudah menguasai seseorang atau massa dan secara tidak langsung akan mampu memaparkan gagasannya sehingga dapat mudah diterima oleh orang lain. Dengan kata lain, bahwa dengan kemahiran berbicara seseorang akan mempunyai manfaat bagi orang lain atau masyarakat misalnya dipercayai menjadi pemimpin (Yant Mujiyanto et al, 2000: 37). Untuk meningkatkan keterampilan berbicara dalam pembelajaran Bahasa Indonesia, salah satunya dengan bermain drama. Karena di dalam permainan drama sangat memperhatikan lafal, intonasi, penghayatan, dan ekspresi. Disamping itu, dengan bermain drama beberapa keterampilanpun dapat dikembangkan misalnya kemampuan berkomunikasi, kemampuan berperan, kemampuan menghafal, menguaktualisasikan diri ke dalam situasi yang dihadapi. Karena itu, kegiatan drama dapat digunakan sebagai sarana dalam menumbuhkan dan mengembangkan berbagai keterampilan berbahasa.

Berdasarkan hasil observasi dan wawancara dengan guru kelas pada saat pembelajaran bermain drama di kelas 4 SD Pintu, maka diketahui faktor penyebab siswa belum mampu bermain drama dengan lafal, intonasi, penghayatan, dan ekspresi yang sesuai karakter tokoh, diantaranya yaitu guru melaksanakan kegiatan pembelajaran bermain drama melalui metode ceramah dan penugasan, siswa hanya membaca dan menghafalkan naskah dramanya saja, tanpa berusaha memahami karakter tokoh yang akan diperankannya. Berdasarkan faktor penyebab kesulitan siswa dalam bermain drama di atas, maka diperlukan suatu tindakan untuk mengatasi permasalahan yang terjadi selama berlangsungnya pembelajaran bermain drama di kelas. Upaya yang dilakukan peneliti adalah dengan menerapkan model pembelajaran kooperatif. Pembelajaran kooperatif adalah suatu model 
pembelajaran yang saat ini banyak digunakan untuk mewujudkan kegiatan pembelajaran yang berpusat pada siswa terutama untuk mengatasi permasalahan guru dalam mengaktifkan siswa yang tidak bekerjasama dengan orang lain (Isjoni, 2007:16). Pembelajaran kooperatif merupakan pembelajaran yang merujuk pada berbagai metode pengajaran dimana para siswa bekerja dalam kelompokkelompok kecil untuk saling membantu satu sama lainnya dalam mempelajari materi pembelajaran (Slavin: 2010;4). Berdasarkan beberapa pendapat para ahli di atas, dapat disimpulkan bahwa dengan penerapan model pembelajaran kooperatif di kelas akan dapat meningkatkan aktivitas belajar siswa yang akan berpengaruh pada hasil belajar siswa karena dalam model pembelajaran kooperatif ini siswa dikelompokkan dengan karakteristik dan kemampuan yang beragam, makasiswa yang kurang akan sangat terbantu dengan siswa yang lebih.

Salah satu model pembelajaran kooperaif yang cocok dalam pembelajaran drama adalah model pembelajaran kooperatif tipe Inside Outside Circle Menurut (Anita Lie, 2008:65), model pembelajaran IOC adalah teknik pembelajaran yang memberikan kesempatan pada siswa agar saling berbagi informasi pada saat yang bersamaan. Menyampaikan pesan pembelajaran secara efektif sesuai dengan teori yang ada. Dengan model pembelajaran IOC siswa ditekankan untuk melakukan kerjasama kelompok, saling berpartisipasi, saling berusaha membantu, saling bertanya, saling memperhatikan, sehingga suasana pembelajaran tidak membosankan, pembelajaran aktif responsive. Menurut Slameto (2010 : 28) Model Pembelajaran Inside Outside Circle (IOC) ini merupakan salah satu tipe dari Cooperative
Learning yang bertujuan untuk melatih peserta didik belajar mandiri dan belajar berbicara, menyampaikan informasi kepada orang lain. Selain itu juga melatih kedisiplinan dan ketertiban peserta didik, serta menumbuhkan kemampuan berfikir mandiri. Menurut Anita Lie (2008: 68) langkah-langkah pembelajaran IOC adalah 1. Separuh kelas berdiri membentuk lingkaran kecil dan menghadap keluar.

2. Separuh kelas lainnya membentuk lingkaran di luar lingkaran pertama, menghadap ke dalam.

3. Dua peserta didik yang berpasangan dari lingkaran kecil dan besarsaling mengungkapkan pemahaman mereka tentang materi yang baru saja diterima. Pertukaran informasi ini bias dilakukan oleh semua pasangan dalam waktu yang bersamaan.

4. Kemudian peserta didik berada di lingkaran kecil diam di tempat, sementara peserta didik yang berada di lingkaran besar bergeser satu atau dua langkah searah jarum jam sehingga masing-masing peserta didik mendapat pasangan baru.

5. Sekarang giliran peserta didik berada di lingkaran besar yang membagi informasi. Demikian seterusnya

Metode pembelajaran Inside Outside Circle mengajak siswa untuk saling bertukar informasi, ada yang member dan ada pula yang menerima informasi dalam waktu yang bersamaan dengan orang yang berbeda-beda. Informasi tersebut dapat berupa materi pembelajaran. Metode ini membuat siswa lebih berpartisipasi aktif dan mengeksplor kompetensi yang mereka miliki dengan pembelajaran yang menyenangkan, santai tapi tetap serius sehingga siswa dapat memahami materi dengan baik. 


\section{METODE}

Penelitian ini merupakan penelitian tindakan kelas (action research classroom) dengan bentuk kolaborasi, yaitu peneliti bekerja sama dengan guru kelas.Penelitian tindakan kelas merupakan terjemahan dari classroom action research, yaitu suatu action research yang dilakukan di kelas sendiri melalui refleksi diri dengan tujuan untuk memperbaiki kinerjanya sebagai guru sehingga hasil belajar siswa menjadi meningkat (Arikunto, 2010: 4). Guru kelas 4 menjadi pihak kolaborator yang melaksanakan pembelajaran yang dirancang oleh peneliti untuk dilaksanakan di kelas dan peneliti sebagai observer dan penanggung jawab penuh penelitian tindakan ini. Tujuan utama dari penelitian tindakan kelas ini adalah meningkatkan keterampilan berbicara dalam bermain drama melalui model pembelajaran kooperatif tipe Inside Outside Circle pada siswakelas 4. Peneliti dan kolaborator terlibat secara penuh dalam perencanaan, tindakan, observasi, dan refleksi pada tiap-tiap siklusnya. Keempat tahapan tersebut saling terkait dan berkelanjutan. Penelitian ini dilaksanakan di SD Negeri Pintu yang terletak di Kecamatan Jenangan Kabupaten Ponorogo. Penelitian ini dilaksanakan pada semester ganjil tahun ajaran 2016/2017 selama lima bulan.

Subjek penelitian adalah siswa kelas 4 SD Negeri Pintu Kecamatan Jenangan Kabupaten Ponorogo tahun ajaran 2016/ 2017, dengan jumlah siswa 20 siswa yang terdiri dari 9 siswa laki-laki dan 11 siswa perempuan. Di kelas tersebut kondisi siswa heterogen (berbeda-beda kemampuannya). Selain siswa, guru juga menjadi subjek penelitian berkaitan dengan kegiatan guru saat mengajar. Objek penelitiannya adalah pembelajaran berbicara dalam bermain drama pada pelajaran Bahasa Indonesia. Strategi penelitian yang digunakan dalam penelitian ini adalah sebagai berikut: a) Tahap perencanaan yang meliputi membuat skenario pembelajaran, mempersiapkan instrumen penelitian, mempersiapkan dan merancang tindakan yang sesuai dengan standar kompetensi dan kompetensi dasar., mengajukan solusi alternative; 2) Tahap pelaksanaan tindakan dilakukan dengan melaksanakan proses pembelajaran sesuai rancangan. Setiap tindakan dan proses pembelajaran tersebut selalu diikuti kegiatan pemantauan; 3) Tiap pengamatan dan interpretasi dilakukan dengan mengamati dan menginterpretasi aktivitas penerapan tindakan pada pembelajaran. Pada tahap interpretasi proses koreksi hasil kerja dilakukan oleh peneliti. interpretasi ini berguna untuk mengetahui apakah tindakan yang dilakukan dapat mengatasi permasalahan yang ada; 5) Tahap analisis dan refleksi dilakukan dengan menganalisis hasil pengamatan dan interpretasi sehingga diperoleh simpulan tentang bagian yang perlu diperbaiki dan bagian yang telah mencapai tujuan penelitian. Dari hasil penarikan kesimpulan tersebut, dapat diketahui apakah penelitian ini mencapai keberhasilan atau tidak. Untuk mempermudah pengumpulan data, penelitian ini menggunakan beberapa teknik. Adapun teknik tersebut antara lain wawancara, dokumentasi, obeservasi dan tes.

Di dalam suatu penelitian diperlukan adanya validitas data, maksudnya adalah semua data yang dikumpulkan hendaknya mencerminkan apa yang sebenarnya diukur atau diteliti. Validitas data dapat diukur dengan teknik triangulasi. Triangulasi berfungsi menekan subjektivitas peneliti. 
Dengan triangulasi, kemungkinan kekurangan yang terdapat pada satu informan akan mendapat pelengkap. Di dalam penelitian ini untuk menguji kesahihan data digunakan triangulasi data dan triangulasi metode. Agar hasil penelitian dapat terwujud sesuai dengan tujuan yang diharapkan maka dalam menganalisis data penelitian ini menggunakananalisis model interaktif Milles dan Huberman. Kegiatan pokok analisa model ini meliputi: reduksi data, penyajian data, kesimpulankesimpulan penarikan / verifikasi (Milles dan Huberman, 1992: 20). Indikator penelitian ini bersumber dari kurikulum dan silabus KTSP Bahasa Indonesia kelas V serta Kriteria Ketuntasan Minimal (KKM), yaitu 73 .

\section{HASIL PENELITIAN DAN PEMBAHASAN}

\section{Kondisi Awal Sebelum Tindakan}

Pengamatan kondisi sebelum tindakan dilakukan untuk mengetahui keadaan nyata yang berada di lapangan. Selain pengamatan, peneliti juga melakukan wawancara terhadap guru kelas 4. Berdasarkan hasil wawancara dan observasi, siswa banyak mengalami kesulitan pada mata pelajaran Bahasa Indonesia. Kondisi ini dikarenakan guru masih belum mengaplikasikan model pembelajaran inovatif. Hal ini ditunjukkan pada hasil nilai tes yang dilaksanakan pada prasiklus. Agar lebih jelas maka kondisi awal (pra siklus) hasil belajar Berbicara dalam Bermain Drama Siswa Kelas 4 SD Negeri Pintu dapat dilihat dari tabel 1 di bawah ini:

Tabel 1. Tabel Data Nilai Keterampilan Berbicara dalam Bermain Drama Siswa Kelas 4 SD Negeri Pintu Pada Kondisi Awal

\begin{tabular}{|c|c|c|c|c|c|}
\hline \multirow[t]{2}{*}{ Tindakan } & \multicolumn{2}{|c|}{ Banyak siswa } & Prosent & (\%) KKM & \multirow[t]{2}{*}{ Rata-rata } \\
\hline & $<\mathrm{KKM}$ & $>\mathrm{KKM}$ & $<\mathrm{KKM}$ & $>\mathrm{KKM}$ & \\
\hline Pra Siklus & 12 & 8 & $60 \%$ & $45 \%$ & 60 \\
\hline
\end{tabular}

Hasil tes diatas menunjukkan nilai rata-rata kelas yaitu 60. Dari 20 siswa kelas 4, siswa yang nilainya dibawah KKM (73) sejumlah 12 siswa dengan prosentase sebesar 60\%. Sedangkan siswa yang mendapat nilai di atas KKM (73) sejumlah 8 siswa dengan prosentase sebesar $45 \%$. Hasil ketrampilan berbicara pada mata pelajaran Bahasa Indonesia yang rendah ini perlu diatasi agar meningkat yaitu dengan menerapkan model pembelajaran kooperatif tipe Inside Outside Circle (IOC).

\section{Deskripsi Siklus I}

Tindakan siklus I dilakukan selama 2 kali pertemuan. Setiap pertemuan terdiri dari dua jam pelajaran $(2 \times 35$ menit $)$ yang dilaksanakan selama satu minggu. Pada tahap ini guru melaksanakan pembelajaran dengan model pembelajaran kooperatif tipe Inside Outside Circle sesuai dengan Rencana Pelaksanaan Pembelajaran (RPP) yang telah disusun. Pada siklus I kegitaan pembelajarannya yaitu siswa menyimak bacaan yang dibacakan guru. Siswa secara bergantian membacakan dialog dalam naskah drama dengan bimbingan guru dengan kelompok lingkaran dalam dan kelompok lingkaran luar berputar berlawan arah searah jarum jam sehingga mendapatkan pasangan yang baru untuk menghayati karakter tokoh dan cara memerankannya dengan lafal, intonasi, 
ekspresi dan penghayatan yang tepat. Setelah selesai berdiskusi siswa kembali ke kelompoknya masing-masing kemudian guru membagikan LKS untuk didiskusikan dan dikerjakan setiap kelompok. Selanjutnya setiap siswa secara bergantian membacakan dialognya. Sedangkan guru menilai kemampuan membaca siswa. Indicator letercapaian pada penelitian ini yaitu $80 \%$ siswa nilainya di atas KKM. Hasil tes pada siklus I dapat dilihat pada tabel dibawah ini:

Tabel 2. Tabel Data Nilai Keterampilan Berbicara dalam Bermain Drama Siswa Kelas 4 SD Negeri Pintu Pada Siklus I

\begin{tabular}{lccccc}
\hline Tindakan & \multicolumn{2}{c}{ Banyak siswa } & \multicolumn{2}{c}{$\begin{array}{c}\text { Prosentase (\%) KKM } \\
(73)\end{array}$} & Rata-rata \\
& \multicolumn{4}{c}{} & \multicolumn{2}{c}{ (7) } & $>$ KKM & $<$ KKM & $>$ KKM & \\
\cline { 2 - 5 } & 5 & 15 & $25 \%$ & $75 \%$ & 65 \\
\hline Siklus I & 5 & & & & \\
\hline
\end{tabular}

Berdasarkan table diatas dapat dilihat bahwa rata-rata kelas pada siklus I telah mengalami peningkatan dari prasiklus. Rata-rata kelas pada siklus I meningkat menjadi 65. Kemudian jumlah siswa yang mendapat nilai diatas KKM (73) juga mengalami peningkatan yaitu dari 12 siswa menjadi 15 siswa. Dan jumlah siswa yang nilainya di bawah KKM (73) mengalami penurunan dari 8 menjadi 5 siswa.

Analisis data dari kolaborasi dengan guru kelas, bahwa beberapa siswa belum mampu menyelesaikan tugas yang diberikan oleh guru secara optimal karena guru belum dapat menyampaikan informasi secara jelas. Hal ini membuat kurangnya ketelitian siswa dalam mengerjakan tugas. Selain itu, masih ada beberapa siswa yang belum menunjukkan keaktifan dalam bertanya. Mereka belum mempunyai keberanian untuk mengungkapkan pendapatnya, kreatifitas dan inisiatif siswa kurang karena mereka belum mampu mengembangkan ide yang dimiliki. Beberapa siswa masih ada yang berbicara dengan temannya diluar materi pelajaran dan masih ada yang belum mampu bekerjasama dengan baik dalam kelompoknya karena belum begitu memahami peranannya dalam kelompok.

\section{Deskripsi Siklus II}

Tindakan siklus II dilakukan selama 2 kali pertemuan. Tiap-tiap pertemuan terdiri dari dua jam pelajaran $(2 \times 35$ menit) yang dilaksanakan selama satu minggu. Perencanaan pada siklus yang kedua ini adalah dengan memperbaiki kekurangan siklus I agar dalam proses pembelajaran di siklus II menjadi lebih baik.Pada tahap ini guru melaksanakan pembelajaran dengan model pembelajaran kooperatif tipe Inside Outside Circle dengan pemantapan dari siklus I. Pembelajaran pada Siklus II yaitu guru menjelaskan mengenai penokohan yaitu karakter tokoh antagonis dan protagonis. Tindakan selanjutnya yaitu elaborasi dengan pendalaman materi kerjasama timbal balik dalam pembelajaran antara guru dan siswa. Dalam kegiatan elaborasi ini siswa menyimak penjelasan dari guru tentang model pembelajaran kooperatif tipe Inside Outside Circle. Selanjutnya guru membagi siswa menjadi 2 kelompok besar yang setiap kelompok besar terdiri dari 10 siswa. Setiap kelompok besar dibagi menjadi 5 orang anggota kelompok lingkaran dalam dan 5 orang anggota kelompok lingkaran luar. Guru bersama 
siswa membaca naskah drama yang sama pada pertemuan sebelumnya. Siswa secara bergantian membacakan dialog dalam naskah drama dengan bimbingan guru dengan kelompok lingkaran dalam dan kelompok lingkaran luar berputar berlawan arah searah jarum jam sehingga mendapatkan pasangan yang baru untuk menghayati karakter tokoh dan cara memerankannya dengan lafal, intonasi, ekspresi dan penghayatan yang tepat.
Setelah selesai berdiskusi siswa kembali ke kelompoknya masing-masing kemudian guru membagikan LKS untuk didiskusikan dan dikerjakan setiap kelompok. Selanjutnya setiap siswa secara bergantian membacakan dialognya. Sedangkan guru menilai kemampuan membaca siswa. Kegiatan konfirmasi, guru bertanya jawab kepada siswa mengenai materi yang telah diajarkan.

Tabel 3. Tabel Data Nilai Keterampilan Berbicara dalam Bermain Drama Siswa Kelas 4 SD Negeri Pintu Pada Siklus II

\begin{tabular}{lccccc}
\hline Tindakan & \multicolumn{2}{c}{ Banyak siswa } & \multicolumn{2}{c}{$\begin{array}{c}\text { Prosentase (\%) KKM } \\
(73)\end{array}$} & Rata-rata \\
\cline { 2 - 5 } & $<$ KKM & $>$ KKM & $<$ KKM & $>$ KKM & \\
\hline Siklus II & 2 & 18 & $10 \%$ & $90 \%$ & 85
\end{tabular}

Berdasarkan pada tabel di atas nilai rata-rata kelas mengalami peningkatan dari siklus I kesiklus II. Rata-rata nilai pada siklus II yaitu 85 . Jumlah siswa yang nilainya diatas KKM (73) yaitu 18 siswa dengan prosentase sebesar $90 \%$. Sedangkan jumlah siswa yang nilainya di bawah KKM (73) sebanyak 2 siswa dengan prosentasese besar $10 \%$. Pada siklus II juga dilakukan diskusi yang mendalam terhadap dialog drama seperti yang dilakukan pada siklus I. Pada lembar observasi aktivitas siswa terjadi perubahan cara berbicara yang cukup berarti. Pada siklus I siswa belum berani dan masih ragu-ragu dalam berbicara, namun pada siklus II siswa sudah mempunyai keberanian untuk berbicara dengan lafal yang jelas dan intonasi yang baik. Demikian juga dalam mengerjakan tugas kelompok atau diskusi, secara keseluruhan siswa sudah memperlihatkan aktivitas yang baik.

Berdasarkan pada penelitian yang telah dilaksanakan dapat diketahui bahwa terjadi peningkatan keterampilan berbicara siswa kelas 4 SDN Pintu pada pelajaran Bahasa Indonesia. Data hasil perkembangan nilai siswa pada tesrasiklus, siklus I dan siklus II dapat dilihat pada Tabel 4 di bawah ini:

Tabel 4. Rekapitulasi perkembangan nilai keterampilan berbicara siswa kelas 4 SDN Pintu pada mata pelajaran Bahasa Indonesia

\begin{tabular}{cccc}
\hline & \multicolumn{2}{c}{ Prosentase jumlah siswa } & Rata-Rata Nilai \\
\hline & $<$ KKM & $>$ KKM & \\
\hline Pra siklus & 12 & 8 & 60 \\
\hline Siklus I & 5 & 15 & 65 \\
\hline Siklus II & 2 & 18 & 85 \\
\hline
\end{tabular}

Dari tabel 4, Rekapitulasi pada mata pelajaran Bahasa Indonesia perkembangan nilai keterampilan dapat disajikan gambar 1 sebagai berbicara siswa kelas 4 SDN Pintu berikut: 


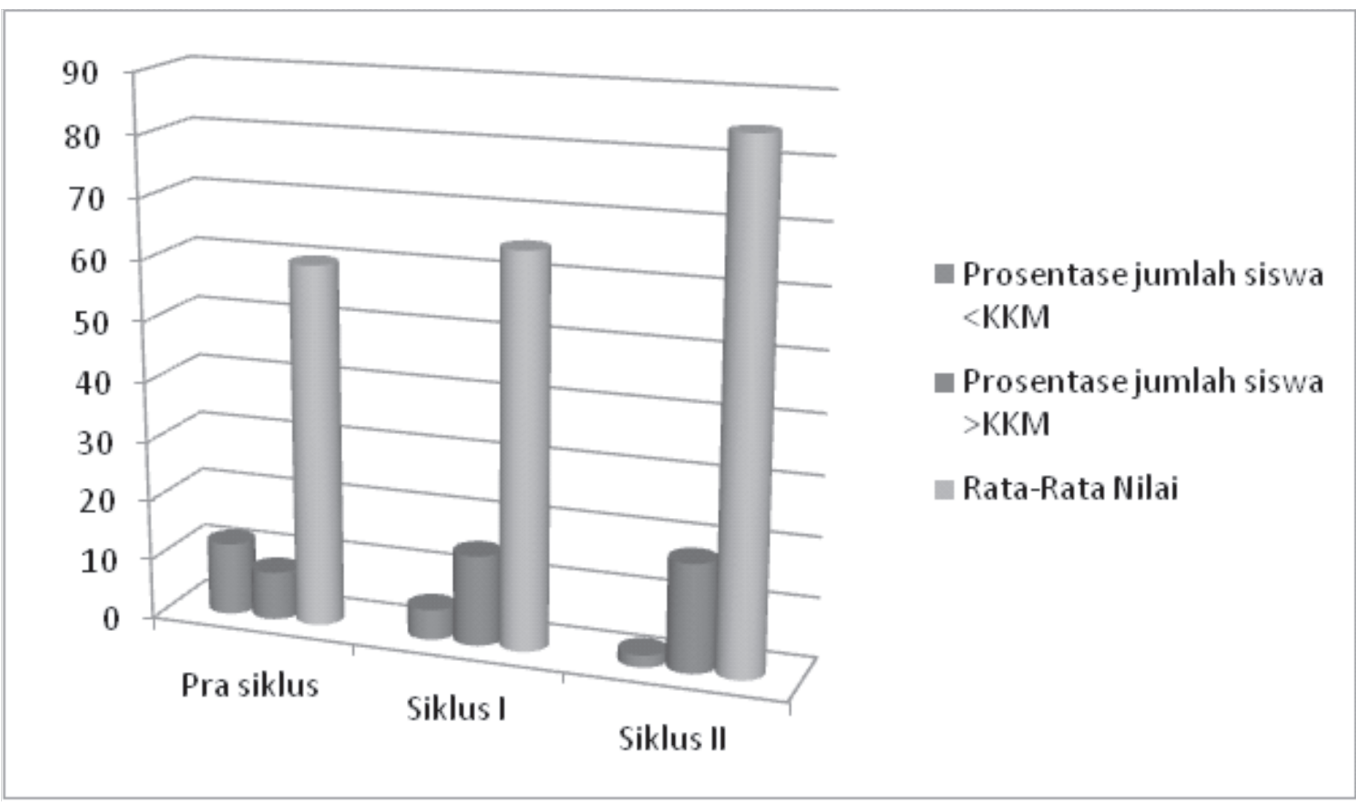

Gambar 1. Grafik Rekapitulasi perkembangan nilai keterampilan berbicara siswa kelas 4 SDN Pintu pada mata pelajaran Bahasa Indonesia

Mengacu pada data tabel 4 dan gambar 1 dapat dilihat bahwa prosentase jumlah siswa $<$ KKM, Prosentase jumlah siswa $>$ KKM dan nilai rata-rata siswa kelas 4 mengalami peningkatan dari pra siklus, siklus I dan siklus II. Hasil penelitian dari beberapa tabel di atas, dapat diketahui adanya peningkatan proses pembelajaran terutama keterampilan berbicara dalam bermain drama siswa terhadap materi pada masing-masing siklus melalui penerapan model pembelajaran kooperatif tipe Inside Outside Circle.

Peningkatan aktivitas siswa dalam mengikuti pembelajaran kooperatif tipe Inside Outside Circle dalam bermain drama adalah pada aspek berikut:

1. Memperhatikan penjelasan dari guru

2. Mengerjakan tugas individu maupun kelompok dengan penuh kesiapan, serius, teliti dan tepat waktu.

3. Keinginan bertanya dan mengungkapkan pendapat

4. Kemauan untuk berdiskusi, bekerjasama dalam menyelesaikan soal.
5. Keaktifan untuk membuat kesimpulan pelajaran,

6. Keaktifan dalam mengikuti proses pembelajaran.

7. Keantusiasan siswa mengikuti pembelajaran

Hambatan-hambatan yang ditemui pada masing-masing siklus berbeda-beda, antara lain: pada siklus I hambatan yang dijumpai adalah guru belum dapat menyampaikan materi dengan jelas dan kurang dapat dipahami oleh siswa karena terlalu cepat dalam menjelaskan sehingga siswa belum memahami langkah-langkah pembelajaran dengan model pembelajaran kooperatif tipe Inside Outside Circle, guru belum memberikan motivasi baik pada individu maupun kelompok sehingga siswa masih belum barani dalam menjawab pertanyaan dan belum mampu bekerjasama dengan kelompoknya. Upaya untuk mengatasi hambatan yang ada pada siklus I yang dilaksanakan di siklus II dalam upaya perbaikan adalah dengan 
memberikan arahan kembali kepada siswa tentang tahapan-tahapan kerja kelompok dengan model pembelajaran kooperatif tipe Inside Outside Circle secara tepat dan jelas, memberi perhatian menyeluruh dan bimbingan terhadap siswa agar pembelajaran lebih kondusif dan memberikan motivasi berupa penghargaan baik secara verbal maupun non verbal kepada siswa agar mereka lebih bisa berekspresi lagi dalam berbicara.

\section{SIMPULAN}

Berdasarkan hasil penelitian tindakan kelas yang dilaksanakan dalam dua siklus tersebut dapat disimpulkan bahwa salah satu upaya untuk meningkatkan keterampilan berbicara pada pelajaran bahasa Indonesia pada siswa kelas 4 SD Negeri Pintu yaitu dengan menerapkan pembelajaran kooperatif tipe Inside Outside Circle. Hal ini terjadi karena pembelajaran dengan model pembelajaran kooperatif tipe inside-outside circle dapat menggali potensi siswa untuk dapat lebih berekspresi dalam berbicara serta aktif mengembangkan kreativitas dan inisiatifnya. Dalam hal tersebut siswa juga dituntut untuk lebih bertanggung jawab pada dirinya sendiri dan orang lain.

Sekolah hendaknya meningkatkan kompetensi guru, karena kompetensi tersebut berpengaruh pada kinerja guru dalam pembelajaran di kelas. Untuk itu, kepala sekolah disarankan untuk memotivasi guru guna meningkatkan kompetensinya agar lebih memperluas wawasan mengenai model-model pembelajaran yang kreatif dan inovatif dalam proses pembelajaran. Untuk itu Peneliti menyarankan penggunaan model pembelajaran kooperatif tipe Inside Outside Circle sebagai model pembelajaran alternatif dalam pembelajaran berbicara dalam bermain drama di SekolahDasar. Penggunaan model pembelajaran kooperatif tipe Inside Outside Circle dapat menciptakan proses pembelajaran yang dapat meningkatkan motivasi berbicara dalam drama siswa

\section{DAFTAR PUSTAKA}

Anita Lie. 2008. Cooperative Learning: Mempraktikkan Cooperative Learning di Ruang-Ruang Kelas. Jakarta: Grasindo

Isjoni. 2007. Cooperative Learning Efektivitas Pembelajaran Kelompok. Bandung: Alfabeta.

Miles, B.B dan A.M. Huberman. 1992.Analisa Data Kualitatif. UI Press Jakarta

Robert. E Slavin. 2010. Cooperative Learning Teori, Riset dan Praktik. Bandung:Nusa Media

Slameto. 2010. Belajar dan FaktorFaktor yang Mempengaruhinya. Jakarta: Rineka Cipta.

Tarigan, Henry Guntur. 2008. Membaca Sebagai Suatu Keterampilan Berbahasa. Bandung: Angkasa.

Yant Mujianto. 2000. BPK Berbicara II. Surakarta: FKIP UNS. 


\title{
PENINGKATAN KETAHANAN PRIBADI SISWA DALAM PELAJARAN MATEMATIKA MELALUI PEMBELAJARAN KOOPERATIF STAD SISWA KELAS XI TKR 2 SMK NEGERI I SINGOSARI
}

\author{
Djulikah \\ SMK Negeri I Singosari Malang \\ Email: djulikah123@gmail.com
}

\begin{abstract}
ABSTRAK
Penelitian ini bertujuan untuk mendekripsikan (1) penggunaan pembelajaran kooperatif STAD untuk meningkatkan ketahanan pribadi siswa dalam pelajaran matematika; (2) hasil penggunaan pembelajaran kooperatif STAD untuk meningkatkan ketahanan pribadi siswa dalam pelajaran matematika. Metode yang digunakan dalam penelitian ini metode deskriptif yang dilaksanakan dalam tiga siklus. Dari siklus ke siklus menggunakan model pembelajaran kooperatif tipe STAD untuk meningkatkan kualitas pelaksanaan belajar kelompok. Lokasi penelitian di Kelas XI TKR-2 SMKN I Singosari. Hasil penelitian menunjukkan bahwa (1) pembelajaran kooperatif tipe STAD dapat meningkatkan ketahanan pribadi siswa SMK Negeri 1 Singosari dalam belajar matematika, (2) ketahanan pribadi siswa meningkat dengan indikator $63 \%$ siswa berani bertanya, $60 \%$ siswa berani berpendapat, $83 \%$ siswa berani memulai mengerjakan tugas dan kebiasaan tidak mencontoh kuis pekerjaan teman baru mencapai $58 \%$.
\end{abstract}

Kata-kata Kunci : Ketahanan Pribadi, Belajar Matematika, Pembelajaran Kooperatif Tipe STAD

\begin{abstract}
This research aimed to describe (1) the use of STAD cooperative learning to improve students' resilience in mathematics lessons; (2) the result of using STAD cooperative learning to improve students' resilience in math lesson. The method used in this research was descriptive method conducted in three cycles. STAD type cooperative learning model used in cycles to improve the quality of group learning implementation. The location of this research was in class XI TKR-2 SMKN I Singosari.The results showed that (1) STAD type cooperative learning could improve personal resilience of students of SMK Negeri 1 Singosari while learning mathematics, (2) personal resilience of students increased with indicator $63 \%$ of students were of active to ask, $60 \%$ of students argued, $83 \%$ of students had initiated to perform assignment and only $58 \%$ of students did not try to cheat others work while undergoing quiz.
\end{abstract}

Key Words: Resilience, Mathematics Learning, STAD Type Cooperative Learning

\section{PENDAHULUAN}

Kurangnya ketahanan pribadi dalam belajar matematika dapat diduga akan berpengaruh besar terhadap gairah belajar matematika. Jika hal ini dibiarkan maka siswa akan semakin tidak menyenangi matematika bahkan pada taraf tertentu akan bersikap anti pati pada pelajaran matematika. Akibat dari itu semua semua tentu prestasi belajar matematika akan semakin rendah.

Matematika dianggap sangat penting bagi kehidupan manusia. Matematika memiliki keterkaitan dan menjadi pendukung berbagai bidang ilmu serta berbagai aspek kehidupan manusia. Tetapi di sisi lain, matematika juga dianggap sebagai mata pelajaran yang 
cukup sulit bagi siswa, bahkan cukup menakutkan bagi beberapa siswa di SMK Negeri 1 Singosari Malang. Hal ini terlihat pada saat pembelajaran berlangsung hampir $60 \%$ diantara para siswa memiliki ketahanan pribadi dalam belajar matematika masih rendah, data yang lain dapat dilihat dari hasil wawancara beberapa siswa. Sedikitnya siswa yang mengajukan pertanyaan dan berani menjawab pertanyaan atau menanggapi pendapat temannya, kurang berani mengambil resiko (takut salah), kebiasaan mencontoh pekerjaan temannya dan kurang terlibat aktif dalam kelompok (cemas), merupakan indikasi lemahnya ketahanan pribadi (keuletan) siswa dalam belajar matematika.

Kondisi di kelas juga diperparah dengan pengelolaan guru dalam proses pembelajaran diantaranya masih kuatnya dominasi guru dalam proses pembelajaran, guru secara aktif menjelaskan materi, memberikan contoh dan latihan, sementara siswa bekerja secara prosedural dan memahami matematika tanpa penalaran, disamping itu guru dalam pembelajarannya masih indoktrinasi yaitu mendudukkan dirinya sebagai maha tahu, maha benar, dan dalam proses pembelajarannya guru belum mengembangkan kemampuan belajar siswa dalam berfikir kritis, logis dan kreatif.

Pada kurikulum 2008 tentang Ringkasan Kegiatan Belajar Mengajar disebutkan bahwa: belajar merupakan kegiatan aktif siswa dalam membangun makna atau pemahaman. Pada buku itu juga disebutkan pula prinsipprinsip Kegiatan Belajar Mengajar diantaranya adalah Berpusat pada siswa, Belajar dengan Melakukan serta Mengembangkan Kemampuan Sosial.
Dengan memperhatikan 3 prinsip Kegiatan Belajar Mengajar yang dikemukakan pada Kurikulum 2008 terlihat bahwa prinsip-prinsip tersebut mengacu pandangan Konstruktivisme yaitu penciptaan kondisi yang memungkinkan siswa untuk mengkonstruksikan pengertian sendiri terhadap suatu konsep sehingga lebih menarik dan bermanfaat bagi siswa, bila dibandingkan dengan jika pengertian tersebut diperoleh secara langsung dari guru, sehingga pembelajaran sering disebut pembelajaran berpusat pada siswa( Siregar 2010). Salah satu bentuk pembelajaran yang berorientasi kepada pendekatan konstruktivis adalah model pembelajaran kooperatif.

Menurut Abdurrahman Asy'ari (2000), belajar hendaknya mampu memberikan bekal "life skills" yang memungkinkan siswa "survive" dalam kondisi yang bagaimanapun. Belajar jangan hanya dimaksudkan untuk mengasah otak, tetapi juga untuk mengasah "qolbu" supaya tercipta rasa positif seperti lebih percaya diri, tabah, tenang, tidak mudah gelisah, mau menghargai orang lain, tidak mematikan semangat orang lain dan pantang menyerah.

Hal-hal diatas memberikan arah bahwa pembelajaran matematika hendaknya tidak boleh melepaskan diri dari proses kerjasama. Dengan bekerja sama, seorang anak yang lebih "dewasa" dalam suatu konsep bisa memberi bantuan kepada temannya untuk mencapai kemampuan idealnya. Dengan bekerja sama, peluang terbentuknya ketrampilan sosial, dan kematangan emosional juga lebih besar. Dan diharapkan dapat pula meningkatkan ketahanan pribadi siswa dalam belajar matematika. 
Hasil penelitian ini diharapkan bermafaat bagi : (1) Bagi siswa, hasil penelitian ini diharapkan bermanfaat dalam meningkatkan ketahanan pribadinya dalam belajar matematika serta memupuk keberaniannya dalam bekerja mandiri. (2) Bagi guru, hasil penelitian dapat bermanfaat dalam inovasi pembelajaran (model pembelajaran kooperatif), dan peningkatan profesionalisme guru (melaksanakan refleksi dalam upaya perbaikan proses pembelajaran). (3) Bagi sekolah, dalam usaha meningkatkan kualitas hasil belajar matematika siswa melalui kolaborasi guru-guru dalam suatu penelitian tindakan kelas.

Untuk mendapatkan gambaran yang lebih jelas, dalam penafsiran hasil penelitian ini, maka perlu diberikan batasan tentang istilah yang terdapat dalam rumusan tujuan penelitian diatas sebagai berikut: (1) Ketahanan pribadi (keuletan) siswa adalah usaha siswa dalam menggali potensi diri. Yang dapat diterjemahkan sebagai tindakan yang dinamis dan berani mengambil resiko dengan indikator : 1) kecemasan siswa berkurang, 2) motivasi, 3) harga diri, dan 4) sikap positifnya meningkat. (2) Pembelajaran kooperatif adalah kegiatan belajar mengajar secara kelompok kecil yang merupakan tempat siswa belajar dan bekerjasama untuk sampai kepada pengalaman belajar yang optimal baik pengalaman individu maupun kelompok. Esensi pembelajaran kooperatif adalah tanggung jawab individu sekaligus kelompok, sehinga dalam diri siswa terbentuk sikap kebergantungan positif yang menjadikan kerja kelompok berjalan optimal (Soedarsono, 1997).

Pada penelitian ini pembelajaran kooperatif yang digunakan adalah tipe STAD yang merupakan teknik belajar kelompok yang memberikan kesempatan kepada siswa untuk berbagi pengetahuan atau tugas dengan siswa lain, mengajar serta diajar oleh sesama siswa. Hal ini merupakan bagian penting dalam belajar.

Pada penelitian ini tujuan utamanya adalah untuk meningkatkan ketahanan pribadi bagi siswa, sebab ditengarai banyak siswa yang kurang ulet dalam belajar matematika. Indikasi dari dugaan tersebut antara lain : 1) belum mampu membebaskan diri dari keinginan menggantungkan diri dari pihak lain, misalnya kebiasaan siswa mencontoh hasil pekerjaan temannya, atau adanya siswa yang sering mengekor pendapat temannya, 2) belum memiliki jiwa dinamis, kreatif dan pantang menyerah, misalnya kebiasaan siswa kurang berani memulai suatu pekerjaan (kurang berani untuk mengambil keputusan walaupun beresiko).

Menurut (Soedarsono,1997) secara esensial seseorang disebut memiliki ketahanan pribadi (keuletan) bila ia : a) Memiliki rasa percaya diri dan berpegang teguh pada prinsip, b) Mampu membebaskan diri dari keinginan menggantungkan diri dari pihak lain, c) Mendambakan kebersamaan, d) Memiliki jiwa dinamis, kreatif dan pantang menyerah.

Siswa yang memiliki ketahanan pribadi yang tinggi akan berusaha menggunakan potensinya sendiri dalam menyelesaikan tugas-tugas yang diberikan dan dia malu apabila harus mencontoh hasil pekerjaan teman-temannya. Siswa akan lebih berani mencoba mengerjakan tugas-tugas (kelompok maupun individu) walaupun secara psikologis resikonya sangat besar menurut siswa, misalnya disalahkan, dicemooh, atau pandangan negatif lainnya. Pada saat pembelajaran kelompok, siswa yang memiliki ketahanan pribadi tinggi akan lebih terbuka, berani 
bertanya, berani mengemukakan pendapat walaupun beresiko, misalnya diejek, dianggap sok tahu, dianggap bodoh dan lain-lain predikat negatif.

Apabila ketahanan pribadi yang tinggi ini sudah tertanam pada diri siswa, maka dapat dipastikan masing-masing siswa memiliki rasa tanggung jawab pribadi yang tinggi juga. Mereka akan dapat mengembangkan potensinya secara optimal sehingga diharapkan akan berdampak positif pada prestasi belajarnya.

Masih banyak guru beranggapan bahwa tugas mereka adalah memindahkan informasi pengetahuan dari buku atau kepala mereka kepada siswa, sedangkan tugas siswa adalah menerima, mengingat, dan menghafalkan informasi tersebut. Dengan kata lain, siswa dianggap sebagai penerima pengetahuan yang pasif sedangkan guru adalah pemilik pengetahuan. Anggapan ini tampaknya didasarkan pada paradigma yang dipopulerkan oleh John Locke (dalam Tilaar 2004), yakni siswa dianggap seperti selembar kertas putih kosong yang menunggu tulisan dari guru. Siswa bagaikan botol kosong yang bisa diisi dengan curahan pengetahuan dari guru, sehubungan dengan ini pula, suasana belajar yang dominan adalah struktur persaingan dimana siswa saling berlomba menjadi lebih baik dari lainnya para guru pun ikut berlomba dengan guru (atau sekolah) lainnya.

Banyak guru menganggap paradigma diatas sebagai satu-satunya jalan. Namun teori dan penelitian menunjukkan bahwa fokus pembelajaran terletak pada belajar secara mendalam dan sesuai dengan pengalaman, memerlukan keterlibatan penuh dan belajar dengan aktif, ketrampilan dikembangkan dalam kaitannya dengan belajar yang relevan (kontektual), materi secara terintegrasi digunakan dan dibentuk oleh siswa. Dengan demikian prinsip utama dalam pandangan kontruktivisme adalah pengetahuan dibangun sendiri oleh siswa (Jonhson \& Johnson, 1994).

Menurut Johnson \& Johnson (dalam Trianto 2009), terdapat lima unsur penting dalam belajar kooperatif, yaitu diantaranya adalah :1) Saling ketergantungan yang bersifat positif antara siswa, dalam belajar kooperatif siswa merasa bahwa mereka sedang saling bekerja sama untuk mencapai satu tujuan dan terikat satu sama lain, sehingga seorang siswa tidak akan sukses kecuali semua anggota kelompoknya juga sukses; 2) Interaksi antara siswa yang semakin meningkat, hal ini terjadi karena seorang siswa akan membantu siswa lain untuk sukses sebagai anggota kelompok. Saling memberikan bantuan ini akan berlangsung secara alamiah karena kegagalan seseorang dalam kelompok akan mempengaruhi suksesnya kelompok dalam memperoleh penghargaan kelompok; 3) Tanggung jawab individual dalam belajar kelompok dalam arti tanggung jawab siswa dalam membantu siswa yang membutuhkan bantuan sehingga siswa tidak hanya sekedar membonceng pada hasil kerja teman sekelompoknya; 4) Ketrampilan interpersonal dalam kelompok kecil, dalam hal ini siswa dituntut aktif dalam bersikap dan menyampaiakan ide sebagai angggota kelompok; 5) Proses kelompok, proses ini terjadi jika anggota kelompok mendiskusikan bagaimana mereka akan mencapai tujuan dengan baik dan membuat hubungan kerja yang baik pula.

Menurut (Anita Lie,1999) beberapa manfaat proses pembelajaran kooperatif adalah sebagai berikut: 1) Siswa dapat 
meningkatkan kemampuan bekerja sama ; 2) Siswa mempunyai lebih banyak kesempatan untuk menghargai perbedaan; 3) Partisipasi siswa dalam proses pembelajaran; 4) Mengurangi kecemasan siswa; 5) Meningkatkan motivasi, harga diri dan sikap positif ; 6) Meningkatkan prestasi akademik.

\section{METODE}

Penelitian ini dilaksanakan di SMK Negeri 1 Singosari, Malang mulai bulan Pebruari 2016 sampai dengan bulan Mei 2016 yang melibatkan dua orang guru matematika (seorang guru menjadi pengajar dan satu orang lainnya menjadi kolaborator) dan 32 siswa kelas XI TKR 2.

Penetapan siswa pada kelas diatas cukup representatif untuk penelitian tindakan kelas sesuai dengan permasalahan yang dihadapi diantaranya memiliki kecenderungan : 1) kurang berani dalam berpendapat, 2) kepercayaan diri rendah, 3) ketergantungan pada teman kuat 4) tidak dinamis dan kurang kreatif.

Menurut Winkel (1996) keberhasilan siswa dalam belajar sangat ditentukan oleh kualitas pembelajaran yang dikelola oleh guru, selanjutnya kualitas pembelajaran tergantung bagaimana guru mendesain pembelajaran tersebut dalam praktek kegiatan belajar, misal : 1) bagaimana guru menyajikan materi, 2) bagaimana guru memberikan penguatan, 3) bagaimana guru melibatkan siswa secara aktif dalam proses belajar dan 4) bagaimana guru menghargai keberhasilan siswa (reward), yang semuanya itu berada dalam satu sistem pembelajaran.

Piaget (dalam Budiningsih,2004) dalam proses belajar siswa menkonstuksi pengetahuan mereka sendiri secara aktif.
Dengan dasar uraian diatas tindakan yang diambil dalam penelitian ini, sebagai upaya meningkatkan ketahanan pribadi siswa kelas XI TKR -2 SMK Negeri 1 Singosari, Malang dalam belajar matematika melalui pembelajaran yang menggunakan pendekatan kooperatif tipe STAD, dengan langkah-langkah sebagi berikut :

Dalam tahap ini materi diperkenalkan melalui penyajian kelas. Penyajian materi dilakukan secara langsung. Kegiatan pembelajaran yang dilakukan pada saat ini adalah :1) Menjelaskan tujuan pembelajaran yang akan dicapai, 2) Memberi motivasi pada siswa tentang perlunya mempelajari materi, 3) Menyajikan materi-materi pokok pembelajaran, 4) Memantau pemahaman tentang materipokok yang diajarkan.

Selama siswa berada pada kegiatan kelompok, masing-masing anggota kelompok bertugas mempelajari materi yang telah disajikan oleh guru dan membantuteman sekelompok untuk menguasai materi tersebut. Guru membagi lembar kegiatan, kemudian peserta didik mengerjakan lembar yang diberikan. Setiap peserta didik harus mengerjakan secara mandiri dan selanjutnyasaling mencocokkan jawaban dengan teman sekelompoknya. Guru harus menekankan bahwa lembar kegiatan untuk dipelajari bukan untuk diisi atau diserahkan pada guru. Jika peserta didik mempunyai pertanyaan sebaiknya ditanyakan terlebih dahulukepada anggota kelompoknya, baru ditanyakan kepada guru bila tak terjawab.

Pelaksanaan kuis individual berlangsung kira-kira setelah satu atau dua periode penyampaian materi oleh guru dan setelah satu atau dua periode kerja kelompok. Dalam pelaksanaan kuis individual akan menentukan keberadaan peserta didik dalam kelompok dan 
keberadaan kelompoknya diantara kelompok-kelompok lain.

Tujuan utama dengan adanya nilai perkembangan individu adalah untuk memberikan hasil akhir yang maksimal pada setiap peserta didik. Untuk menentukan nilai perkembangan peserta didik digunakan prosedur pada tabel berikut sebagai berikut :

Tabel : 1 Penentuan Nilai Perkembangan Individu

\begin{tabular}{ccc}
\hline \multicolumn{1}{c}{ Langkah $\boldsymbol{k e}$ - } & \multicolumn{1}{c}{ Indikator } & \multicolumn{1}{c}{ Operasional } \\
\hline 1 & $\begin{array}{l}\text { Menetapkan skor } \\
\text { dasar }\end{array}$ & $\begin{array}{l}\text { Setiap peserta didik diberikan skor } \\
\text { berdasarkan skor dari hasil ulangan } \\
\text { harian yang lalu }\end{array}$ \\
\hline 2 & $\begin{array}{l}\text { Menghitung skor } \\
\text { kuis terkini }\end{array}$ & $\begin{array}{l}\text { Peserta didik memperoleh poin untuk } \\
\text { kuis yang berkaitan dengan materi } \\
\text { pokok terkini }\end{array}$ \\
\hline 3 & $\begin{array}{l}\text { Menghitung skor } \\
\text { perkembangan }\end{array}$ & $\begin{array}{l}\text { Peserta didik mendapatkan poin } \\
\text { perkembangan yang besarnya } \\
\text { ditentukan apakah skor kuis terkini } \\
\text { mereka menyamai atau melampaui skor } \\
\text { dasar mereka, dengan menggunakan } \\
\text { skala yang diberikan dibawah ini }\end{array}$ \\
\hline \multicolumn{2}{c}{ Kriteria } & Nilai Perkembangan \\
\hline $\begin{array}{l}\text { Lebih dari 10 poin di bawah skor dasar } \\
\text { 10 poin di bawah sampai 1 poin di bawah } \\
\text { skor dasar }\end{array}$ & 10 poin \\
\hline $\begin{array}{l}\text { Skor dasar sampai 10 poin di atas skor } \\
\text { dasar }\end{array}$ & 20 poin \\
\hline Lebih dari 10 poin di atas skor dasar & 30 poin \\
\hline $\begin{array}{l}\text { Pekerjaan sempurna (tanpa } \\
\text { memperhatikan skor dasar) }\end{array}$ & \\
\hline
\end{tabular}

Dalam Slavin (1994), pembelajaran kooperatif mengidentifikasikan bahwa teamreward dan pertanggunganjawab individual adalah esensi dari basic skill achievement. Untuk menentukan penghargaan kelompok digunakan kriteria berikut ini:

Tabel 2. Penentuan Penghargaan Kelompok

\begin{tabular}{lllc}
\hline Nilai Kelompok (N) & $15 \leq \mathrm{N}<20$ & $20 \leq \mathrm{N}<25$ & $\mathrm{~N} \geq 25$ \\
\hline Penghargaan & Baik & Hebat & Super \\
\hline
\end{tabular}

(1) Mengurangi dominasi guru dalam proses pembelajaran, guru berperan sebagai fasilitator, manajer, dan konsultan dalam proses belajar. (2) Meningkatkan pemahaman guru dalam mengidentifikasi materi yang sesuai dengan penggunaan pendekatan kooperatif tipe STAD. (3) Penyampaian materi disederhanakan, sehingga member kesempatan kepada siswa untuk mengonstruksi pengetahuannya. Menyederhanakan materi mengandung arti menurunkan tingkat kesukaran/ kompleksitas materi untuk disesuaikan 
dengan tingkat kematangan berfikir siswa. (4) Membentuk kelompok belajar yang heterogen. Dengan kelompok belajar yang heterogen diharapkan siswa dapat meningkatkan kemampuan bekerjasama, siswa mempunyai lebih banyak kesempatan untuk menghargai perbedaan serta partisipasi siswa dalam proses belajar meningkat. (5) Melalui diskusi kelompok, siswa dapat mengurangi kecemasan, meningkatkan motivasi, harga diri, dan sikap positifnya.

Tindakan yang dipilih untuk meningkatkan ketahanan pribadi siswa dalam belajar adalah melaksanakan pembelajaran kooperatif tipe STAD.

Langkah-langkah yang dilakukan dalam pelaksanaan tindakan adalah sebagai berikut: (1) Mendesain pembelajaran yang sesuai dengan rencana pengajaran yang telah disiapkan dan menyampaikan tujuan pembelajaran sejelas mungkin. (2) Membentuk delapan kelompok yang masing-masing beranggotakan empat orang siswa yang heterogen. (3) Menyampaikan pesan kepada siswa tentang tugas-tugas yang harus dikerjakan baik secara individu maupun kelompok. (4) Setiap anggota mendapatkan satu materi untuk diselesaikan.

(5) Memantau efektifitas kerja kelompok dan menyediakan bantuan kepada siswa (misalnya: menjawab pertanyaan yang sifatnya pancingan, memahami materi) untuk memaksimalkan kerja kelompok. Sehingga kebergantungan positif antara anggota kelompok dalam mempelajari materi secara utuh dapat berjalan dengan optimal. (6) Mengevaluasi hasil kerja siswa dengan penilaian proses maupun hasil.

\section{HASIL DAN PEMBAHASAN}

Fokus pengamatan dalam penelitian ini, yaitu : 1) respon siswa dalam belajar matematika melalui pembelajaran kooperatif tipe STAD 2) peranan guru didalam kelas selama tindakan berlangsung.

\section{SIKLUS 1}

Pada siklus I hasil pengamatan oleh observer terhadap respon siswa dalam belajar matematika dengan pembelajaran kooperatif tipe STAD, tampak siswa masih canggung dalam berdiskusi. Hal ini tampak dari ; 1) mimik siswa yang tampak cemas dalam belajar kelompok, 2) sedikit siswa yang berani bertanya, 3) tidak banyak siswa yang berpendapat, 4) dalam mengerjakan soal kuis cenderung mencontoh pekerjaan temannya, dan 5) tidak kreatif dan mudah menyerah sebagaimana disajikan dalam tabel berikut.

Tabel 3. Frekuensi Respon Siswa Dalam Belajar TerhadapPembelajaran Kooperatif Tipe STAD

\begin{tabular}{|c|c|c|c|c|c|}
\hline \multirow[t]{2}{*}{ No } & \multirow{2}{*}{$\begin{array}{l}\text { Respon yang } \\
\text { Diamati }\end{array}$} & \multirow[t]{2}{*}{ Indikator } & \multirow[t]{2}{*}{ Frekuensi } & \multicolumn{2}{|c|}{ Prosentase } \\
\hline & & & & Item & Rata-rata \\
\hline \multirow[t]{3}{*}{1.} & Ketidakcemasan & - Berani berpendapat & 8 & $25 \%$ & \\
\hline & & - Berani bertanya & 7 & $22 \%$ & $25 \%$ \\
\hline & & - Berani memulai tugas & 9 & $28 \%$ & \\
\hline \multirow[t]{2}{*}{2.} & Motivasi dalam & - Belajar sambil bekerja & 3 & $9 \%$ & \\
\hline & Belajar & - Belajar menggunakan media & 13 & $41 \%$ & $25 \%$ \\
\hline \multirow[t]{2}{*}{3.} & Harga diri & - Menjawab pertanyaan & 4 & $13 \%$ & \\
\hline & & $\begin{array}{l}\text { - Tidak mencontoh hasil pekerjaan } \\
\text { teman }\end{array}$ & 10 & $31 \%$ & $22 \%$ \\
\hline \multirow[t]{2}{*}{4.} & Sikap positif dalam & - Menanggapi respon teman lain & 5 & $16 \%$ & \\
\hline & belajar & - Kerjasama dalam kelompok & 14 & $44 \%$ & $30 \%$ \\
\hline
\end{tabular}


Dari tabel diatas tampak dalam proses diskusi hanya $25 \%$ dari jumlah siswa yang berani berpendapat, 22\% yang berani bertanya, 38\% siswa yang berani memulai tugas, sehingga hanya $25 \%$ orang siswa yang tidak cemas dalam kegiatan belajar mengajar didalam kelas. Untuk respon kedua, dari jumlah siswa yang ada hanya $9 \%$ yang mau belajar sambil bekerja, dan $41 \%$ siswa mau memanfaatkan lembar materi yang ada untuk belajar, sehingga hanya $25 \%$ dari jumlah siswa yang bermotivasi untuk belajar. Sedangkan respon yang ketiga. 13\% siswa mampu menjawab pertanyaan baik dari teman atau pancingan dari guru, $31 \%$ siswa sudah tidak mau mencontoh hasil pekerjaan temannya, sehingga $22 \%$ siswa mempunyai harga diri yang lebih dari yang lainnya. Untuk respon keempat, 16\% siswa yang berani menanggapi masalah temannya melalui kegiatan diskusi kelompok dan presentasi kelompok, dan $44 \%$ mempunyai keinginan bekerjasama dalam diskusi kelompok. Sehingga Sikap positif dalam belajar siswa $30 \%$. Sementara siswa lain terlihat cemas atau takut dalam berdiskusi sehingga cenderung menjadi penggembira saja.

Dari hasil pengamatan peranan guru selama mengelola pembelajaran kooperatif tipe STAD diperoleh informasi bahwa pelaksanaan pembelajaran untuk persiapan, kegiatan pendahuluan, kegiatan inti, ketrampilan kooperatif, kegiatan penutup, pengelolaan waktu serta suasana kelas adalah baik. Namun demikian masih dijumpai dalam kegiatan pembelajaran didalam kelas ternyata guru masih sering terlihat :(1) mendominasi kegiatan belajar mengajar sehingga siswa kurang diberi kesempatan untuk menkonstruksi pengetahuannya, (2) siswa dibiarkan mencari anggota kelompoknya sendiri, sehingga pembentukan kelompok tidak heterogen, (3) intervensi terhadap kelompok tidak berupa pancingan tetapi cenderung langsung memberikan jawaban yang ditanyakan siswa, (4) tidak konsisten dengan rencana yang telah diprogramkan dan terburu-buru.

\section{SIKLUS II}

Dari hasil refleksi dan evaluasi tindakan pada siklus I, maka perlu dilakukan sedikit perubahan pada rencana tindakan pada siklus II, yaitu : (1) Dibentuk kelompok belajar yang baru dengan melibatkan guru dalam menentukan anggota masing-masing kelompok agar menjadi kelompok yang heterogen. (2) Bantuan yang diberikan kepada siswa dalam kegiatan diskusi harus berupa pancingan agar siswa dapat menemukan jawabannya sendiri. (3) Peranan guru hanya sebagai fasilitator, manager, dan konsultan pada kegiatan pembelajaran, sehingga intervensi guru jika diperlukan saja. (4) Guru selalu memperhatikan alokasi waktu yang ada pada perencanaan, sehingga sesuai dengan waktu tindakan. (5) Siswa diberikan kesempatan seluas-luasnya mendiskusikan masalahnya. Hasil pengamatan tindakan pada siklus II diperoleh data respon siswa sebagai berikut.:

Tabel 4. Respon Siswa Terhadap Pembelajaran KooperatifTipe STAD Pada Siklus II

\begin{tabular}{|c|c|c|c|c|c|}
\hline \multirow[t]{2}{*}{ No. } & \multirow[t]{2}{*}{ Respon yang Diamati } & \multirow[t]{2}{*}{ Indikator } & \multirow[t]{2}{*}{ Frekuensi } & \multicolumn{2}{|c|}{ Prosentase } \\
\hline & & & & Item & Rata-rata \\
\hline \multirow{3}{*}{1.} & Ketidakcemasan & - Berani berpendapat & 11 & $34 \%$ & \\
\hline & & - Berani bertanya & 13 & $41 \%$ & $46 \%$ \\
\hline & & - Berani memulai tugas & 20 & $63 \%$ & \\
\hline \multirow[t]{2}{*}{2.} & Motivasi dalam Belajar & - Belajar sambil bekerja & 5 & $16 \%$ & \\
\hline & & - Belajar menggunakan media & 24 & $75 \%$ & $45 \%$ \\
\hline \multirow[t]{2}{*}{3.} & Harga diri & - Menjawab pertanyaan & 6 & $19 \%$ & \\
\hline & & - Tidak mencontoh hasil pekerjaan teman & 14 & $44 \%$ & $31 \%$ \\
\hline \multirow[t]{2}{*}{4.} & Sikap positif dalam & - Menanggapi respon teman lain & 5 & $16 \%$ & \\
\hline & belajar & - Kerjasama dalam kelompok & 24 & $75 \%$ & $45 \%$ \\
\hline
\end{tabular}

Dzulikah, Peningkatan Ketahanan Pribadi Siswa dalam Pelajaran Matematika Melalui Pembelajaran Kooperatif STAD Siswa Kelas XI TKR 2 SMK Negeri I Singosari 
Dari tabel diatas dapat diperhatikan bahwa terdapat kenaikan respon siswa untuk semua deskriptor. Untuk deskriptor pertama, yaitu tidak cemas dalam belajar ada kenaikan yang signifikan dibandingkan pada siklus pertama yaitu meningkat sekitar 21\%. Untuk deskriptor kedua, motivasi dalam belajar naik sekitar $20 \%$, untuk deskriptor ketiga juga mengalami kenaikan sebesar 9\%, dan deskriptor keempat naik sebesar 15\%. Meskipun semua deskriptor persentasinya mengalami kenaikan dibandingkan dengan hasil yang diperoleh pada siklus I, untuk deskriptor keempat khususnya indikator berani menanggapi respon tidak mengalami kenaikan. Sehingga pada tindakan selanjutnya indikator ini perlu mendapat perhatian.

Peranan guru selama mengelola pembelajaran kooperatif tipe STAD diperoleh informasi bahwa pelaksanaan pembelajaran untuk persiapan, kegiatan pendahuluan, kegiatan inti, ketrampilan kooperatif, kegiatan penutup, pengelolaan waktu serta suasana kelas adalah baik.
Dalam kegiatan pembelajaran pada siklus II, sudah sesuai dengan perencaan, yaitu sebagai fasilitator, manajer, dan konsultan. Namun untuk bimbingan yang diberikan kepada kelompok tidak seimbang antara kelompok yang satu dengan kelompok yang lain. Hal ini sebabkan oleh kondisi kelas yang tidak menunjang pembelajaran kooperatif tipe STAD.

\section{SIKLUS III}

Sehubungan dengan hasil yang dicapai pada siklus II, maka masih dipandang perlu dimunculkan siklus III dengan refleksi yang telah disepakati oleh tim peneliti pada diskusi mingguan, yaitu dengan penekanan pada : (1) Memaksimalkan diskusi kelompok. (2) Memaksimalkan bimbingan belajar baik secara kelompok maupun individu dengan pancinganpancingan yang merangsang siswa untuk aktif dan kreatif. (3) Data respon siswa pada siklus III, yang diamati oleh tim peneliti dalam tindakan disajikan pada tabel berikut:

Tabel 5. Respon Siswa Terhadap Pembelajaran Kooperatif Tipe STAD Pada Siklus III

\begin{tabular}{|c|c|c|c|c|c|}
\hline \multirow[t]{2}{*}{ No. } & \multirow{2}{*}{$\begin{array}{l}\text { Respon yang } \\
\text { Diamati }\end{array}$} & \multirow[t]{2}{*}{ Indikator } & \multirow[t]{2}{*}{ Frekuensi } & \multicolumn{2}{|c|}{ Prosentase } \\
\hline & & & & Item & Rata-rata \\
\hline \multirow[t]{3}{*}{1.} & Ketidakcemasan & - Berani berpendapat & 19 & $59 \%$ & \\
\hline & & - Berani bertanya & 20 & $63 \%$ & $69 \%$ \\
\hline & & - Berani memulai tugas & 27 & $84 \%$ & \\
\hline \multirow[t]{2}{*}{2.} & Motivasi dalam & - Belajar sambil bekerja & 6 & $19 \%$ & \\
\hline & Belajar & $\begin{array}{l}\text { - Belajar menggunakan } \\
\text { media }\end{array}$ & 27 & $84 \%$ & $52 \%$ \\
\hline \multirow[t]{2}{*}{3.} & Harga diri & - Menjawab pertanyaan & 14 & $44 \%$ & \\
\hline & & $\begin{array}{c}\text { - Tidak mencontoh hasil } \\
\text { pekerjaan teman }\end{array}$ & 23 & $72 \%$ & $58 \%$ \\
\hline \multirow[t]{2}{*}{4.} & $\begin{array}{l}\text { Sikap positif } \\
\text { dalam belajar }\end{array}$ & $\begin{array}{l}\text { - Menanggapi respon } \\
\text { teman lain }\end{array}$ & 13 & $41 \%$ & $61 \%$ \\
\hline & & $\begin{array}{c}\text { - Kerjasama dalam } \\
\text { kelompok }\end{array}$ & 26 & $81 \%$ & \\
\hline
\end{tabular}


Dari tabel diatas, dapat dilihat bahwa semua deskriptor maupun indikator yang ditetapkan persentasenya mengalami kenaikan yang cukup baik. Deskriptor pertama, kedua, ketiga dan keempat kenaikannya berturut-turut 23\%, 7\%, 27\% dan $16 \%$. Meskipun persentasi yang dicapai oleh deskriptor rata-ratanya hampir mencapai $60 \%$, namun untuk indikatorindikatornya masih ada yang jauh dibawah $60 \%$, misalnya: belajar sambil bekerja baru $19 \%$, menjawab pertanyaan baru $44 \%$, dan menanggapi respon teman lain juga baru $41 \%$.

Ditinjau dari peranan guru selama mengelola pembelajaran kooperatif tipe
STAD diperoleh informasi bahwa pelaksanaan pembelajaran untuk persiapan kegiatan pendahuluan, kegiatan inti, ketrampilan kooperatif, kegiatan penutup, pengelolaan waktu serta suasana kelas adalah baik, demikian juga tindakan guru selama berlangsungnya tindakan pada siklus III, sudah sesuai dengan perencanaan yang telah disiapkan. Namun mengingat kondisi kelas dan banyaknya kelompok yang ada dalam satu ruangan kurang dapat mendukung penerapan pembelajaran kooperatif tipe STAD, sehingga sampai berakhirnya siklus III bimbingan yang diberikan guru baik secara kelompok maupun individu kurang maksimal.

\section{HASIL DAN PEMBAHASAN}

Tabel 6.Perkembangan Ketahanan Pribadi SiswaDari Siklus Pertama Sampai Dengan Ketiga

\begin{tabular}{|c|c|c|c|c|c|c|c|c|c|c|c|}
\hline \multirow{3}{*}{ No. } & \multirow{3}{*}{$\begin{array}{c}\text { Respon yg } \\
\text { diamati }\end{array}$} & \multirow{3}{*}{ Indikator } & \multicolumn{9}{|c|}{ SIKLUS } \\
\hline & & & \multicolumn{3}{|c|}{ Pertama $(2 \mathrm{X})$} & \multicolumn{3}{|c|}{ Kedua $(2 \mathrm{X})$} & \multicolumn{3}{|c|}{ Ketiga (2X) } \\
\hline & & & Frek & Persen & Rt-rt & Frek & Persen & Rt-rt & Frek & Persen & Rt-rt \\
\hline \multirow[t]{3}{*}{1.} & Ketidak & - Berani berpendapat & 8 & $25 \%$ & & 11 & $34 \%$ & & 19 & $59 \%$ & \\
\hline & cemasaan & - Berani bertanya & 7 & $22 \%$ & $25 \%$ & 13 & $41 \%$ & $46 \%$ & 20 & $63 \%$ & $69 \%$ \\
\hline & & - Berani memulai tugas & 9 & $28 \%$ & & 20 & $63 \%$ & & 27 & $84 \%$ & \\
\hline \multirow[t]{2}{*}{2.} & Motivasi dalam & - Belajar Sambil bekerja & 3 & $9 \%$ & & 5 & $16 \%$ & & 6 & $19 \%$ & \\
\hline & Belajar & - Belajar Menggunakan media & 13 & $41 \%$ & $25 \%$ & 24 & $75 \%$ & $45 \%$ & 27 & $84 \%$ & $52 \%$ \\
\hline \multirow[t]{2}{*}{3.} & Harga Diri & - Menjawab Pertanyaan & 4 & $13 \%$ & & 6 & $19 \%$ & & 14 & $44 \%$ & \\
\hline & & $\begin{array}{l}\text { - Tidak Mencontoh. Hasil } \\
\text { Pekerjaan Teman }\end{array}$ & 10 & $31 \%$ & $22 \%$ & 14 & $44 \%$ & $31 \%$ & 23 & $72 \%$ & $\begin{array}{l}58 \\
\%\end{array}$ \\
\hline \multirow[t]{2}{*}{4.} & Sikap Positif & - Menanggapi respon teman lair & 5 & $16 \%$ & & 5 & $16 \%$ & & 13 & $41 \%$ & \\
\hline & dalam Belajar & - Kejasama dalam kelompok & 14 & $44 \%$ & $30 \%$ & 24 & $75 \%$ & $45 \%$ & 26 & $81 \%$ & $61 \%$ \\
\hline
\end{tabular}

Dari hasil penelitian diatas ditemukan bahwa melalui pembelajaran kooperatif tipe STAD secara klasikal ketahanan pribadi siswa kelas XI TKR 2 SMK Negeri 1 Singosari Malang ada peningkatan dari siklus I ke siklus II, dari siklus II ke siklus III.

Dari keempat deskriptor ketahanan pribadi siswa yang diobservasi selama pelaksanaan tindakan didalam kelas sampai tindakan pada siklus III, ternyata sudah mencapai 69\% siswa yang rileks (tidak cemas), 52\% siswa yang mempunyai motivasi tinggi, $58 \%$ siswa yang menghargai dirinya, dan $61 \%$ siswa yang bersikap positif dalam belajar. Namun apabila dikaitkan dengan indikator keberhasilan dalam penelitian ini, ternyata sampai dengan siklus III anak yang berani bertanya sudah mencapai $63 \%$, berani berpendapat $59 \%$, berani memulai tugas $84 \%$, dan yang suka mencontoh hasil kuis pekerjaan teman turun sampai $41 \%$, yaitu dari $31 \%$ pada siklus I menjadi $72 \%$ pada siklus III. Dari uraian diatas, dari keempat indikator keberhasilan yang telah ditetapkan 
tiga indikator berhasil dicapai, sedangkan satu indikator, yaitu tidak mencontoh hasil pekerjaan teman pada saat mengerjakan kuis yang di target turun sampai $60 \%$, baru terpebuhi $41 \%$.

Untuk meningkatkan ketahanan pribadi siswa, dalam menyusun lembar materi guru telah mengusahakan dalam bentuk kontekstual. Untuk mendekati pola belajar untuk belajar. Menurut Winkel (1992:63) cara "belajar untuk belajar" dapat diajarkan pada anak yang tidak begitu pandai. Dari hasil penelitian ini bahwa peningkatan kemampuan siswa dalam belajar untuk belajar (yang diidentikan dengan belajar sambil bekerja) peningkatannya relatif kecil, yaitu 5\% dari siklus I ke siklus II dan 5\% dari siklus II ke siklus III. Rendahnya persentase kenaikan kemampuan siswa dalam belajar untuk belajar dapat dimaklumi, mengingat memperbaiki ketrampilan siswa dalam belajar untuk belajar ini merupakan masalah yang penuh tantangan bagi usaha pendidikan, hal ini dikatakan oleh Gredler (dalam Burhanuddin 2014).

Mengingat guru adalah penanggung jawab utama kegiatan pembelajaran dan pembelajaran kooperatif temasuk jenis pembelajaran yang mandiri, maka ada dua upaya yang harus dilakukan oleh guru sebelum pembelajaran kooperatif berlangsung, yaitu pertama, meyiapkan kemampuan dasar guru yang berkaitan dengan prasyarat esensial, yaitu kemampuan sebagai fasilitator, manajer, dan konsultan. Yang kedua menyiapkan prasyarat pendukung, seperti penyusunan lembar materi merupakan salah satu upaya mengurangi kecemasan siswa dalam belajar kelompok. Akan tetapi upaya itu akan efektif, jika prasyarat esensial terpenuhi. Disamping itu peranan guru dalam kelas baik sebagai fasilitator, manajer, maupun konsultan sangat penting bagi peningkatan ketahanan pribadi siswa. Kesabaran guru dalam mendampingi siswa akan membiasakan siswa aman bagi siswa dan menambah hasrat untuk berprestasi dalam belajar.

\section{SIMPULAN}

Hasil analisis ini memberikan simpulan sebagai berikut. Dari hasil analisis data dan pembahasan pada penelitian ini dapat disimpulkan hal-hal berikut ini : 1) pembelajaran kooperatif tipe STAD dapat meningkatkan ketahanan pribadi siswa kelas XI TKR-2 SMK Negeri 1 Singosari, Malang dalam belajar matematika.2) proses pembelajaran kooperatif tipe STAD dapat meningkatkan ketahanan pribadi siswa kelas XI TKR-2 SMK Negeri 1 Singosari Malangdalam belajar matematika; 3) ketahanan pribadi siswa meningkat dengan indikator $63 \%$ siswa berani bertanya, 59\% siswa berani berpendapat, $84 \%$ siswa berani memulai tugas/pekerjaan dan kebiasaan tidak mencontoh kuis pekerjaan teman baru mencapai 58\%.

Berdasarkan temuan penelitian, disarankan kepada semua guru mata pelajaran matematika agar: 1) memberikan kesempatan siswa untuk mengkontruksi pengetahuannya sendiri dan berusaha untuk melakukan penelitian dalam upaya meningkatkan profesionalisme guru; 2) mempersiapkan kelas khusus yang memberikan kebebasan siswa dan guru untuk bergerak dalam pembelajaran kooperatif; 3) meningkatkan kemampuan guru dalam mengelola kelas, terutama yang berhubungan dengan bimbingan atau bantuan terhadap siswa dalam kegiatan diskusi. 


\section{DAFTAR PUSTAKA}

Anita lie. 2002. Cooperative Learning. Jakarta: PT. Gramedia Widiasarana Indonesia

As'ari, Abdurrahman. 2000. Pembelajaran Matematika yang Demokratis. (makalah). FMIPA UM, Malang.

As'ari, Abdurrahman. 2003. Penggunaan Komputer (Multi Media) Dalam Konteks Pembelajaran Matematika Dengan Strategi Cooperative Learning. (makalah). FMIPA UM, Malang.

Budiningsih,Asri (2012 ).Belajar dan Pembelajaran.Jakarta : Rineksa Cipta.

Burhanuddin ,Afid.2014 .Prinsip - Prinsip Belajar Dan Implikasinya.

https://afidburhanuddin.wordpress.com/.../ prinsip-prinsip-belajar-danimplikasinya-4/diakses 27 Agustus 2017

Gredler ,1994 Belajar dan Membelajarkan. Jakarta: P T Radja, Grafindo

Siregar, Eveline. Nara, Hartini. 2010. Buku Ajar Teori Belajar dan Pembelajaran. Jakarta. Ghalia Indonesia.

Slavin,Robert E.2008.Cooperative Learning (Teori dan Praktek). Bandung : Nusa Dua

Soedarsono, 1997.Ketahanan Pribadi dan Ketahanan Keluarga sebagai Tumpuhan Ketahanan nasional. Jakarta : Internusa.

Tilaar.H.A.R. 2004 Paradigma Baru Pendidikan Nasional.Jakarta : Rineka Cipta

Trianto. 2009 Mendesain Model Pembelajaran Inovatif dan Progresif . Jakarta: Kencana Prenada Group

Winkel,1996.Psikologi Pengajaran,Jakarta Grasindo. 


\title{
AN INTERPRETIVE STUDY OF THE COMMUNICATION NEEDS OF ENGLISH DEPARTMENT STUDENTS AT UNIVERSITY OF MUHAMMADIYAH MALANG
}

\author{
Dwi Poedjiastutie, Kharisma Naidi W.S, Teguh Hadi S, Aninda N.H \\ FKIP UniversitasMuhammadiyah Malang \\ Email: dwi.poedjiastutie@postgrad.curtin.edu.au
}

\begin{abstract}
At English Department (ED) UMM, students learn communication for General Purposes (GE) and the generality of the communication materials very much depend on the teachers' decisions. In other words, teachers can decide any topics and materials depending on the communication books they possessed and read. Even so, many of them by the end of their study period are still not able to speak English fluently. This research is to provide information needed for the curriculum development and classroom instruction through Needs Analysis (NA). The research questions for this study cover (1) what communication skills and competence are expected by ED UMM students? To answer the following questions, an interpretive research paradigm will be employed in the proposed research. In an interpretive research paradigm, theories are constructed from the data rather than theories preceding the data. The data in this research is the participants' goals, reasons, motives, feelings, perspectives, and assumptions and these participant perspectives will be viewed through the lens of their cultural contexts. This approach uses three-stage data collection and analysis, namely: FGD (focus-group interview) with ED students. The findings showed:There are three areas that both English Department and Faculty of Education should give more attention for the improvement of students' communication competence. The goals of speaking subject should be made clear by having the students' voices heard and employing the appropriate Needs Analysis (NA) study. The second was the speaking teacher recruitment process should be made transparent. Last but not least is the importance for English Department to understand students' expectations of how speaking subjects should be run and implemented so that they will achieve communication development.
\end{abstract}

Key words: Needs Analysis, Interpretive Study, Communication Needs

\section{RINGKASAN}

Pemilihan materi mata kuliah speaking di jurusan Bahasa Inggris sangat tergantung pada pengajar atau pengampu mata kuliah tersebut. Silabus mata kuliah speaking sering kali hanya menjadi dokumen resmi tanpa penerapan yang jelas terutama dimata kuliah tersebut. Hal ini ditenggarai membuat hasil belajar terutama kemampuan berkomunikasi mahasiswa Bahasa Inggris menjadi rendah. Penelitian ini ditujukan mencari jawaban atas permasalahan tersebut. Apakah silabus mata kuliah Bahasa inggris terutama speaking tidak diikuti oleh banyak pengajar speaking sendiri. Untuk mencari motives atau alasan mengapapengajar bertindak seperti itu pendekatan kwalitatif digunakan oleh penulis. Data dikumpulkan dengan melakukan wawancara individu kepada dosen pengampu mata kuliah speaking dan wawancara kelompok dengan mahasiswa yang menempuh mata kuliah speaking. Hasilnya adalah baik Fakultas Keguruan dan Ilmu Pendidikan dan Jurusan Pendidikan Bahasa Inggris harus Bersama-sama memperhatikan tiga hal yaitu. Meningkat kemampuan dosen untuk 
ketrampilan Analisa kebutuhan (NA), rekruitmen dosen Speaking yang sifatnya transparan tidak sekedar native speaker dan tujuan pengajaran speaking yang bergradasi antara speaking yang terendah (basic) sampai yang tertinggi (advance)

\section{INTRODUCTION}

The current status of English as an international or global language is evident by its wide use in a range of fields such as politics, diplomacy, international trade and industry, commerce, science and technology, education, the media, information technology, and popular culture (Crystal, 2003; Huda, 2000; Jenkins, 2003). English is increasingly used as a medium of instruction in schools and universities and is also taught widely as a foreign language for students intending either further study in an English speaking country or as a requirement for employment (Lauder, 2008).The international value of English as a lingua franca, has led to a commitment by the government of Indonesia to the teaching of English at all levels of education.

The relationship between English and employability is a significant one. Employability can be viewed as the ability to get a job, maintain it or get a new one (Kirubahar, Santhi, \&Subashini, 2010). In some cases, and especially so in current times in Indonesia, this will depend on the ability to speak English fluently and to effectively communicate one's ideas orally as well as having competence in reading and writing in English. Although Coleman (2010) argues that several earlier studies have failed to find convincing evidence linking English competence to the economic development of the individual or nation, other recent studies suggest that there may indeed be a positive relationship between English competence and employability. For this reason, it is not surprising that the teaching of English as a Foreign Language (EFL) is continue to occur at tertiary level in Indonesia. Many university students are now aware the relevance of having communicative competence to their future careers. This is in contradiction with Focho (2010) had claimed that English teaching in most developing country is problematic since students may fail to see its relevance to their immediate or future needs.

Nowadays English is the dominant language of communication worldwide, even among non-native speakers. Due to that English also plays a significant role in the curriculum at UMM. Located in Malang, Indonesia, UMM is the largest private Islamic University in East Java Province with a total of 18,000 students from different parts of Indonesia. The English Department UMM (ED UMM) is the most frequently selected higher education destination for senior high school graduates in East Java. Since 1999, the ED UMM has accepted approximately 250 students each year.

In 2012, a tracer study was conducted by ED UMM staff in which a questionnaire was distributed to 2000 students from the academic years 2009 to 2011. From this research, it was found that the majority of ED UMM graduates on completion of the first degree intended to be job seekers rather than pursuing higher degrees. Further, the study reported that students expected that studying English as a means of global communication would prepare and equip them with the necessary language competency required for future employment (Tracer Study, 2012). More 
than $80 \%$ indicated their intention to go into jobs as English teachers, from primary to university level, with less than $20 \%$ indicating that they would go into other professions (English Department Tracer Study, 2012).

In many workplace situations communication is needed. For example, research conducted by Ghenghesh (2013) has indicated that the engineering students felt the need of communication skills for engineering purposes. While Brunton (2009) sought needs information on Hotel employees. Chen (2006) focused more on communication needs of the bank employees.

At English Department (ED) UMM students learn communication for General Purposes (GE) and the generality of the communication materials very much depend on the teachers' decisions. In other words, teachers can decide any topics and materials depending on the communication books they possessed and read. For example, the syllabus mentions very general information on the communicative competence that students must possess and master. Even so, many of them by the end of their study period are still not able to speak English fluently.

The low and lack communication capability will definitely disadvantage students since they are going to compete for the future jobs inside or outside the country. The values of their educational investment can be useless.

To address this concern, several steps have been taken to improve ED UMM students' level of English competence including redesigning the English curriculum. However, despite the obvious need to first do so, there has been no systematic analysis of needs when attempts are made to tailor the curriculum or the classroom instruction to the particular needs of UMM teaching graduates.

This is a practice contrary to that recommended in the literature, especially with regard to implementing curriculum changes. For example,Hamp-Lyons (2001)and Finney (2002) argue that a needs analysis has a vital role in the process of designing and carrying out any language course, whether it be English for Specific Purposes (ESP) or general English courses.

In addition,I. Leki (2003) suggests English courses are more beneficial if the goals reach beyond the class as an end in itself towards the real needs of learners and other stakeholders. Moreover, it is the existing institutions' responsibility (e.g., ED UMM) to know and to anticipate the future needs of stakeholders and society (Oliver et.al, 2012). Collecting and analyzing data on needs allows teachers to describe the gap between what has been done and what is needed to be done. Thus, a needs analysis can support the development and implementation of language policies at both macro and micro levels, with far-reaching consequences.

The research problems of the current study as follows:

What are English Department communication needs from students' own perspectives?

\section{METHOD}

An interpretive research paradigm was employed in the proposed research. In an interpretive research paradigm, theories are constructed from the data rather than theories preceding the data (Erlandson, Harris, Skipper, \& Allen, 1993). The data in this research is the participants' goals, reasons, motives, feelings, perspectives, and assumptions (Fraenkel, Wallen, \& 
Hyun, 2012) and these participant perspectives will be viewed through the lens of their cultural contexts

In this study learners' perceptions of communication needs were ascertained using focus group interviews. The participant were ED UMM students enrolled in all academic year. There are 16 students from different academic years attended two Focus Group Discussions (FGD). . Each focus group was limited up to 8 students, as this has been found to be the optimum number of participants for focus group research (Fraenkel, et.al, 2012, p. 423). Different focus groups was be conducted until it emerges from the ongoing thematic analysis of responses that no more new perspectives are revealed, that is until saturation is reached.

A think-aloud process wasemployed to analyze the data obtained through the focus group interviews with studentsto find out the emergent themes and typological dimensions (Lincoln \& Guba, 1985, p. $335)$ or it is known as new categories.

\section{RESULT AND DISCUSSION}

The Focus Group Discussion (FGD) was conducted twice with different group of students and in two different schedules. Before elaborating the result, it is important to describe students who studied at ELED this university.

The students at UMM are very diverse in terms of their backgrounds home location, ethnicity, socio-economic backgrounds, and the level of their knowledge of the Islamic religion. In addition, there are also a small percentage of non-Muslim students enrolled at the university. In the coming years, it is predicted that the proportion of new students from Malang will be equal to the number of students coming from other regions in East Java. Students coming from
East Indonesia are predicted to increase significantly.

The unit responsible for English language teaching at UMM is the Department of English Language Education, also known as the English Department (ELED UMM). Graduates of ED UMM usually go into teaching careers at primary to high school levels.

\section{The Goals of Speaking Course}

Almost all students said that to be able to communicate was their first priority to master compared to the other skills. Many students agree that communication in general will help them to secure jobs. This is a bit contradictory with the expectations by the teacher. Teachers wanted the syllabuses were modified to meet students' communication skills for GE and Academic English. As a matter of fact, when they graduated from ELED, some FGD participants wanted to go for careers other than teaching such as international motivators, translation center, flight attendance, teachers in overseas higher education. Therefore, many of them said that communication was still critical.

- If you work in a translation company don't you think that writing and translation skills are more important than communication one?

- I think communication is also important to market or to promote the existence of this business. I think it is useless if we do run business but none knows the business. Communication is still important to spread the information to wider community (KRH)

No matter what the job is, in communication, students should be able to do presentation, discussion, and argumentation, not just making a conversation. These three skills are 
considered important in their future life whether they were going into a certain career or pursuing higher education. However, one student was really expressed surprising point of view. She expected that in teaching speaking, teachers should be able to integrate several teaching modes at a time: discussion, problem solving, and presentation.

\section{The students' preference of the speaking teachers}

Students at the FGD have a variety of point of views regarding to speaking teachers. Some of them preferred to have English native speakers in their speaking class. When they were asked further about their understanding of English native speakers, they did not really give uniform information. Some of them said that native speaker can be anyone as long as they did not speak Bahasa Indonesia,

$D$ : What do you mean by native speakers?

F: Their mother tongue is English or I mean as long as they are not Indonesian, they can be from Netherland, Rumania, Finland, China, Japan, etc.

Others said that native speaker is someone from English speaking countries such as United States, Australia, British, and New Zealand. Still others argued that as long as they were physically European people even though English was not their first language. The reason for having overseas teachers according to some students was since they cannot speak Bahasa. This is the key for imitation that the English should be like.

- When I cannot deliver my opinion in English, I will try my best in whatsoever I can to make him understand what I am saying. But if the lecturer is Indonesian, I will have a tendency to use Bahasa when they did not understand my opinion in English.

Other student at FGD expressed concerns about overseas teachers for not understanding the local students' cultures. These students suspected that the ELED chairman might only focus physical appearance as long as they are physically different from local students. According to the students, they did not even know what to teach in speaking subject. They were mostly confident only teaching material related to their background of knowledge. Students wanted the ELED chairman are more serious in selecting their speaking teachers especially those who were from overseas. The examples below are from students:

- In terms of the native teachers, I think the department should make an agreement with them. Because the case I found was when they taught students and students have the argumentation on a particular topic, they forced students to agree and say that you are wrong and I'm right. So it is impacted to students' skill of communication. Using that way, students did not really want to talk. After that case, students felt really afraid to give their opinion. The English Department should make agreement or to set teaching rules so this will not happen again. And native speakers did not use whatever they want to use in their teaching. They should know at least our cultures too.

- I had the experience when we were in speaking 2, my speaking teachers were from overseas. She taught us mostly something related to financial, management and it 
made me think that actually we did not need these materials. At first we never know what her academic background but when she frequently taught about ATM and piggy bank and some kinds of materials, we thought that she had management background. However, she did not know what she should teach us as the ED students.

Some students expressed that if the teachers are not from English speaking countries, the teachers should be really good at speaking and high critical thinking so that they can give good feedback. According to this student the communication competence matters much compare to the ethnicity.

However, with local teachers, students also expressed concerns. Teachers' capacity and delivery skills need to be securitized. Student at FGD argued that the speaking class was far from being interesting. Teachers focus more on the grammar. Thus, it frightened everyone since they are afraid of making mistakes while speaking. In addition, the topics given by the lecturer was not interesting either. They said that the speaking materials were similar to what they had learnt when they were in Senior High School. They need more challenging materials to improve the vocabulary and richen their English expression.

\section{The Students' Beliefs and Expectations}

Students also expressed belief that the catastrophic of students' undeveloped speaking skills was due to the leader's the lack of determination. Students claimed that they need leaders (managerial level personnel) are supposed to become a role model for everyone study at English Department at this target university. The leaders' determination personality helped to enforce students to speak and practice English not only in speaking class but also outside the class. Hence, this will create the English exposure and be able to lift the students up to the betterment of their communication level. In addition to that, the leaders' determination also plays crucial steps to reduce the teachers' denial attitudes. At FGD students expressed some teachers' irresponsible attitude such as coming very late for the class, too many absences for speaking class without prior notice so students felt that they got nothing in their speaking class. The ELED chairman was supposed to remind these teachers not just to let these things happened again and again.

- $\quad$ The first important thing we need is the effectiveness of teaching and process. Effective here is "no wasting time", but we can get more good results. But, up to now, I still don't get anything yet. What I mean here is, the lecturer should give us various materials, so that we can get more knowledge and improve our speaking skill. Sometimes, the lecturer only focus on one material for few meetings, that makes us really bored. The last important thing is the commitment of lecturer's attendance. My speaking lecturer has so many absences for this semester. She/he missed the class very often (NBL)

However, some students believed that the inadequacy of speaking skills were not merely due to teachers. Many students did not seem ready to accept challenges. They enrolled at the ELED for different reasons and their reasons determined their level of motivation. For example, some students are really genuine to improve their 
communication competence but some were not and being passive in the class. Therefore, they argued that perhaps, in addition to teaching skills, teachers should be able to create a class atmosphere where students' confidence will grow.

Students felt regretted as they have almost completed speaking subjects (Speaking 1, Speaking 2, Speaking 3, and Speaking 4), but they felt that their speaking skills did not improve significantly. As a matter of fact, several students claimed that the number of speaking classes set by the ELED did not really improve the speaking skill unless they also participate in English Day. They further described many students kept saying in Bahasa Indonesia during the English Day. There are some programs established by the ELED to facilitate students communicating not only when they were at classroom meetings. Those are English Day and Weekly Discussion.

The English Day is the two days- Monday and Wednesday- where all students must speak and communicate in English with both other students enrolled at English Department regardless their academic years and ELED teachers. All students at ELED were recommended to go to campus either for class schedule or just for socialization. Everyone are recommended to use the pin - "Speak English with me". It is as a reminder that English should be used elsewhere in the campus.

However, since at the Faculty of Education, there are also many students not only from ELED but also from other Departments- Biology, Mathematics, Indonesian, Civic Study, and Primary School Teachers-and many times they were mix especially outside the classroom meetings. this further complicated the supervision. When they were not obviously seen by the ELED teachers, they tended to speak Indonesian, except for very highly motivated students. So far, the ELED has not yet designed systematic ways to increase the number of participation from the students.

- I think more speaking classes (in the university) doesn't really help because language is habit. If you use it every day or continuously, you will get used to it. Although you have so many speaking classes, but you only use your English in the classroom, I think it will be useless. Let's think, how many hours you speak English in the class. Maybe, it less than one hour per meeting. Do you think that will help? I don't think so. We need to use it in our everyday life actually. Fortunately, we have English day in our department on Monday and Wednesday that force us to speak English outside the class. That's a good program actually. But, in reality it doesn't work. That's what makes me sad. We lacked of support from the department. Some students really try to speak whole English during English day, but not for the others. We do need support from the department to run this program well, so we can speak English each other more often.

- The department should have certain rules for the lecturers. The department also needs to pay attention on the surrounding, I mean to see whether the ELED students already speak English or not (related to English Day). We need to find out the systematic way to run the English Day. Maybe by giving punishment for those who don't speak English during English 
Day and reward for those who already speak whole English.

Even though students argued that to be able to speak English was their priority, they found some challenges in improving the communication level. The first most cited difficulties were to invite other students to speak English both in and outside the class due to the lack of determination and support from the ELED chairman and teachers. Besides, the selection of speaking teachers need urgent attention from ELED chairman especially their teaching qualification, delivery skill, pedagogical knowledge, and their communication skills.

A fundamental part of a need analysis entails the inclusion of learners' perspectives as a key component. This is because learners invest their time, money, and energy in learning knowledge and skills with the expectation that their investment will be useful. The expectations of students have been researched by many scholars (Evan and Green, 2007; Hyland, 1997; Leki and Carson, 1994). For example, Hyland (1997) surveyed 1619 students from eight disciplines at five Hong Kong tertiary institutions. Hyland's study revealed that students generally saw the value of English for Academic Purposes (EAP) classes as they recognize that proficiency in English is an important determinant of academic success in an English-medium learning environment. However, the students' perspectives on the need for language instruction varied according to their proficiency level, discipline and year of study. The findings indicated that less proficient students attached more importance to English classes than their more linguistically able counterparts that the subjects' language problems centered on the productive skills of writing and speaking, and, the acquisition of specialist vocabulary.

At a more specific skill level, numerous studies have examined different English language learning needs, for example, aural/oral communication needs (Ferris \&Tagg, 1996; Ferris, 1998). Others have examined writing needs (e.g., Casanave\& Hubbard, 1992; Jenkins, Jordan, Weiland, 1993; Afzali and Fakharzadeh, 2009; Huang, 2010). For instance, Huang (2010) reports on findings from a research project designed to assess undergraduate and graduate students' language-learning needs in the context of a new academic language support center at a Canadian university. A total of 432 students and 93 instructors of English as an Additional Language responded to questionnaires which asked them to rate the importance of academic writing. The findings indicated that there was much overlap in the skill items identified as being 'very important' by the graduate and undergraduate students and the instructors. However, students' self-assessments of their own writing skills and instructors' assessments of their students' writing skills differed dramatically. Even so, it is clear that learners have particular perspectives regarding their needs and these should be documented.

This study shows similarity to what Poedjiastutie and Oliver (2017) study thathad been conducted in the past two years. They states that it is apparent there are problems with communication. Upon graduation many students have achieved only minimal English proficiency.

\section{CONCLUSION}

This study clearly identified mismatches 
between the ED UMM curriculum and the students' learning needs. The findings from the stakeholders revealed several challenges at the program administration at the level of faculty, and the classroom.

There are three areas that both English Department and Faculty of Education should give more attention for the improvement of students' communication competence. The first is dealing with the speaking syllabuses. The goals of speaking subject should be made clear by having the students' voices heard and employing the appropriate Needs Analysis (NA) study. The second was the speaking teacher recruitment process should be made transparent. Either overseas or local teachers are supposed to follow the goals of teaching speaking, the teaching qualification and capacity that have been determined by the English Department. Last but not least is the importance for English Department to understand students' expectations of how speaking subjects should be run and implemented so that they will achieve communication development.

Students at UMM have pragmatic reasons for learning. They want to be able to communicate and master all the English language skills that will help them in their prospective careers, to gain overseas work and/or placement in international programs. They provided a number of suggestions of ways English teaching at UMM could be improved. Two of the main findings in this regard are improving the teaching capacity of staff at the institution and redefining several ELED and University policies related to pedagogy (e.g., smaller class size and streaming ESP classes based on proficiency). It is clear that to further enhance the students' success in English learning, some of the behaviours observed in the classrooms need to change.

Where English is a foreign language, as in Indonesia, it can be very difficult for language learners to find out opportunity to use it for communication because the society does not use it for daily interactions. Yet wider exposure to English would give students greater opportunities for using and, therefore, learning the target language. However, teachers can select particular groups or individuals who are committed English users and provide opportunities for students to meet with them. For example, this can be done by teachers inviting native speakers or expatriates who were living in locally to address their classes. Some exchange students from the ACICIS (Australian Consortium in Countries of Indonesian Study) program, Peace Corps, and exchange students from different parts of the world at UMM could also be invited to share their experiences and description of their cultures in English. Such activities could be conducted either regularly or as an incidental program. This would be particularly effective for speaking and listening classes as models of different English varieties could be provided by such classroom guests. In addition, teachers could invite some English school teachers, English courses instructors, parents who are able to speak English etc. to functions held for students at UMM. The more opportunities the teachers can create for students to hear English spoken and use their own English skills, the more confident students will become.

As revealed from both the FGDs, the majority students want English as a central part of the curriculum. However, many also demonstrated behaviour that suggested they were avoiding using it. This may occur as many students reported 
having negative English learning experiences during their high school years due to the focus on grammar teaching. Fortunately, there are many opportunities to engage with English at UMM. For example, the International Language Foundation is one of the English-speaking clubs for UMM students in which students have opportunities to use English for public speaking and debating. In addition, several units at UMM have their own English programs that students from any departments would be welcome to attend. For example, American Corner has a Movie Show program, conducted every month and often has guest lectures from the key persons from the USA discussing a variety of topics. However, these various opportunities need to be supported and promoted by the teachers and by UMM more generally.

\section{REFERENCES}

Afzali, K., \&Fakharzadeh, M. (2009). A needs analysis survey: The case of tourism letter writing in Iran. ESP World, 22(1). Retrieved from http:// www.esp-world.info/Articles_22/PDF/ $\mathrm{A} \% 20$ needs $\% 20$ analysis $\% 20$ survey. pdf

Brunton, M.W.C. (2009). An evaluation of students' attitudes to the general English and specific components of their course: a case study of hotel employees in Chiang Mai - Thailand. ESP World, Issue 4(25), Volume 8, 2009. Retrieved from http://www.espworld.info/Articles_25/ESP\% 20world\%20study.pdf

Casanave, C. P., \& Hubbard, P. (1992). The writing assignment and writing problems of doctoral students: Faculty perceptions, pedagogical issues, and need research. English for Specific Purposes, 11, 33-49.
Chen, Y. (2006). From the common core to specific. Asian ESP Journal, 1(3), Retrieved from http://www.asian-espjournal.com/June_2006_yc.php

Coleman, H. (2010). The English language in development. Retrieved from www.teachingenglish.org.uk/ transform/book

Crystal, D. (2003). English as a global language (2nd ed.). Cambridge: Cambridge University Press.

Erlandson, D.A., Harris, E.L., Skipper, B.L., \& Allen, S.D. (1993). Doing naturalistic inquiry: A guide to methods. Newbury Park, CA: Sage Publications.

Evans, S., \& Green, C. (2007). Why EAP is necessary: A survey of Hongkong tertiary students. Journal of English for Academic Purposes, 6, 3-17.

Ferris, D. (1998). Students' views of academic aural/oral skills: A comparative needs analysis. TESOL Quarterly, 32(2), 289-318.

Ferris, D., \&Tagg, T. (1996). Academic oral communication needs of EAP learners: What subject matter instructors actually require. TESOL Quarterly, 30(1), 31-58.

Finney, D. (2002). The ELT curriculum: A flexible model for a changing world. In J. C. Richard, \&Renandya, W.A. (Ed.), Methodology in language teaching: An anthology of current practice (pp. 69-79). Cambridge: Cambridge University Press.

Focho, G. N. (2010). Language as tool for global education: Bridging the gap between the traditional and global curriculum. Journal of Research in Innovative Teaching, 3(1), 135-148. Fraenkel, J. R., Wallen, N.E., \& Hyun, H.H. (2012). How to design and evaluate research in education (8th ed.). New York: Mc Graw-Hill. 
Ghenghes, P. (2013) Students and teachers of engineering speak out! What do you really need? AWEJ, 4 (1), $11-27$.

Hamp-Lyons, L. (2001). English for academic purposes. In R. Carter, \&Nunan, D. (Ed.), The Cambridge guide to teaching English to speakers of other languages (pp. 126-130). Cambridge: Cambridge University Press.

Huang, L. (2010). Seeing eye to eye? The academic writing needs of graduate and undergraduate students from students' and instructors' perspectives. Language Teaching Research, 14(4), 517-539. Retrieved from http:// ltr.sagepub.com website:

Huda, N. (2000). Kedudukan dan fungsi bahasa asing (The position and function of foreign languages). In $\mathrm{H}$. Alwi, \&Sugono, D. (Ed.), Politikbahasa: risalah seminar politikbahasa (Language politics: procedings of the seminar on language politics).(pp. 59-78). Jakarta: Pusat Bahasa dan Departemen Pendidikan Nasional.

Hyland, K. (1997). Is EAP necessary? A survey of Hong Kong undergraduates. Asian Journal of english Language Teaching, 7, 77-99.

Jenkins, J. (2003). World Englishes: A resource book for students. London and New York: Routledge English Language Introductions

Jenkins, S., Jordan, M.K.J., \& Weiland, P.O. (1993). The role of writing in graduate engeenering education: A survey of faculty beliefs and practices. English for Specific Purposes, 12, 51-67.

Kirubahar, J. S., Santhi, V.J., \&Subhashini, A. (2010). Personal and labour market environment factors in English for employability: A case study of KSA. Language in India, 10(4), 21-
29. Retrieved from www. language ini ndia.com website:

Kitkauskiene, L. (2006). General English and English for specifi c purpose. Santalka Filologija Edukologija, 14 (2), 88-92.

Lauder, A. (2008). The status and function of English in Indonesia: A review of key factors. Makara, Social Humaniora, 12(1), 9-20.

Leki, I. (2003). Research insights on second language writing instruction (Publication no. EDO-FL-03-06). Available from ERIC Clearing House on Language and Linguistics Washigton, DC

Leki, I., \& Carson, J.G. (1994). Students' perceptions of EAP writing instruction and writing needs across disciplines. TESOL Quarterly, 28(1), 67-79.

Lincoln, Y. \& Guba, E. (1985). Naturalistic Inquiry. Beverly Hills, CA: Sage.

McCawley, P. F. (2009). Methods for conducting an educational needs assessment: Guideliness for cooperative extention system professionals. Moscow: University of Idaho.

Netiksiene, N. (2006). Teaching English for specifi c purposes. Santalka Filologija Edukologija, 14(4), 80-82.

Oliver, R., Grote, E., Rochecouste, J., \&Exell, M. (2012). Addressing the language and literacy needs of aboriginal high school VET students who speak SAE as an additional language. The Australian Journal of Indigenous Education 41(2), 1-11.

Poedjiastutie, D. and Oliver,R. (2017). Exploring Students' Learning Needs: Expectation and Challenges. ELT Journal 10 (10), 124-133. DOI: https://doi.org/10.5539/elt. v10n $10 \mathrm{p} 124$ 


\title{
PENERAPAN MODEL PEMBELAJARAN MAKE $A$ MATCH UNTUK MENINGKATKAN HASIL BELAJAR MATEMATIKA TENTANG PEMBAGIAN PADA SISWA KELAS II SD MUHAMMADIYAH 4 BATU
}

\author{
Mariani \\ SD Muhammadiyah 4 Batu \\ Email: marianisubandi66@yahoo.com
}

\begin{abstract}
ABSTRAK
Dalam pembelajaran matematika SD, guru sering mengalami kendala dalam mengajarkan materi tentang pembagian. Penelitian ini bertujuan untuk meningkatkan hasil belajar tentang materi pembagian pada materi pembagian untuk menentukan pasangan bilangan pembagian yang hasil baginya diketahui dengan penerapan model pembelajaran Make a Match. Untuk mencapai tujuan penelitian tersebut digunakan penelitian kualitatif jenis penelitian tindakan kelas, dengan model pembelajaran Make a Match dalam penelitian ini dilakukan dengan menggunakan kartu soal dan kartu jawaban. Adapun kegiatan yang dilakukan dalam penelitian ini adalah identifikasi masalah, perancangan tindakan, pengumpulan data, serta analisis data yang dilaksanakan dalam dua siklus dengan focus yang berbeda. Analisis yang dilakukan terhadap data yang diperoleh dengan teknik deskriptif kualitatif berdasar hasil observasi terhadap pemahaman dan hasil belajar siswa. Hasil penelitian menunjukkan bahwa prestasi belajar siswa mengalami peningkatan. Hal ini dapat dilihat dari rerata hasil belajar siswa pada siklus I yaitu 77,8 dan rerata hasil belajar pada siklus II menjadi 92,5.Ketuntasan hasil belajar siswa meningkat dari jumlah siswa yang tuntas sebanyak 17 siswa dengan persentase klasikal sebesar 56,7 \% pada siklus I menjadi 29 siswa dengan persentase klasikal sebesar $87,5 \%$ pada siklus II, hal ini menunjukkan adanya peningkatan hasil belajar melebihi kriteria keberhasilan yaitu $>75 \%$.
\end{abstract}

Kata kunci: Hasil Belajar Matematika, Pembagian, Model Pembelajaran Make A Match

\begin{abstract}
In elementary school mathematics, teachers often experience obstacles in teaching material about Division. This research aims to improve the learning outcomes of the Division material to determine the pair of number of Divisions whose results are known by the application of the Make a Match learning model. To achieve the purpose of the research, the researcher used qualitative research type of classroom action research, in which the Make a Match learning model in this research is conducted by using question cards and answer cards. The activities undertaken in this study is the identification of problems, actions design, data collection, and data analysis carried out in two cycles on different focus. The analysis conducted on the data obtained by qualitative descriptive technique based on the results of observation on the understanding and student learning outcomes. The results showed that student achievement has increased. This can be seen from the average of student learning outcomes in the first cycle score of 77.8 and the average of learning outcomes in cycle II with the score of 92,5 . The student completed learning outcomes increased from the number of students who complete as many as 17 students with the classical percentage of $56.7 \%$ in the first cycle to 29 students with the classical percentage of $87.5 \%$ in cycle II , this indicates an increase in learning outcomes exceeds the success criteria of $>75 \%$
\end{abstract}

Key words: Mathematics Learning Outcomes, Division, Learning Model Make A Match 


\section{PENDAHULUAN}

Matematika merupakan salah satu mata pelajaran yang dirasa paling sulit dibandingkan dengan pelajaran yang lain terutama bagi siswa di tingkat/jenjang pendidikan dasar. Kesan ini diyakini sebagai salah satu penyebab kurang berminatnya sebagian besar siswa untuk belajar matematika. Banyak upaya sudah dilakukan agar matematika menjadi pelajaran yang menyenangkan. Berbagai metode dan pendekatan belajar telah dikembangkan agar siswa menyenangi matematika.

Berdasarkan pengamatan sebelum diadakan penelitian tindakan kelas, menunjukkan bahwa siswa yang belum paham pada materi pembagian $30 \%$ dari 32 siswa yang ada di kelas II SD Muhammadiyah 4 Batu. Kenyataan di lapangan menunjukkan bahwa siswa kelas 2 masih kurang mampu dan kurang terampil dalam melakukan pembagian. Hal ini disebabkan oleh beberapa hal diantaranya karena siswa kurang antusias dalam proses pembelajaran. Hal ini nampak ketika dalam proses pembelajaran tentang materi pembagian banyak siswa yang kurang memperhatikan diantaranya beberapaa siswa berbicara dengan temannya ada juga yang bergurau dengan teman di sebelahnya. Siswa juga merasa kesulitan dengan cara guru dalam mengajarkan pemahaman konsep tentang pembagian yang kurang benar, hal ini terlihat dari ketika siswa mengerjakan soal latihan hanya 15 dari 33 siswa saja yang bisa mengerjakan dan beberapa siswa yang lainnya tidak bisa mengerjakan (soal dijawab dengan jawaban sekehendak hatinya sendiri). Sehingga rerata hasil belajar masih belum maksimal atau belum mencapai KKM yang telah ditentukan.
Dalam pembelajaran matematika di Sekolah Dasar kelas II, guru pun sering mengalami kendala dalam mengajarkan materi tentang pembagian. Misalnya dalam mengajarkan materi pembagian khususnya mengetahui pasangan bilangan pembagian yang hasil baginya diketahui, hal ini karena guru kesulitan dalam menentukan media dan memilih model pembelajaran yang tepat untuk digunakan dalam proses pembelajaran. Di sisi lain, dalam proses pembelajaran pemilihan model atau metode yang digunakan guru masih bersifat konvensional dan masih menggunakan metode ceramah sebagai satu-satunya metode yang digunakan tanpa melibatkan siswa dalam proses belajar, sehingga belajar siswa kurang bermakna.

Dengan melihat permasalahan diatas, tampak bahwa proses pembelajaran belum berjalan optimal. Diduga akar penyebab masalahnya adalah metode atau model pembelajaran yang digunakan guru selama ini kurang melibatkan siswa. Mengacu pada pemikiran ini, peran guru sebagai motivator memiliki inisiatif dan inovatif untuk menciptakan proses belajar mengajar lebih menyenangkan, dapat memotivasi siswa agar lebih aktif yaitu salah satunya dengan mengemas pembelajaran bermain bebas, anak berinterkasi langsung dengan benda-benda konkrit sebagai bagian dari aktivitas belajar. Sehingga pembelajaran yang demikian akan menjadi lebih bermakna. Belajar bermakna merupakan landasan utama untuk terbentuknya mathematic connections, yaitu pembelajaran matematika yang mengarah pada pengembangan kemampuan mengembangkan ide matematik, memahami ide matematik, dan penggunaan metode (Suryadi, 2007:165). 
Menurut Rusman (2012: 223-233) Model Make A Match (membuat pasangan) merupakan salah satu jenis dari metode dalam pembelajaran kooperatif. Metode ini dikembangkan oleh Lorna Curran (1994). Salah satu cara keunggulan teknik ini adalah peserta didik mencari pasangan sambil belajar mengenai suatu konsep atau topik, dalam suasana yang menyenangkan. Monalini meneliti hasil belajar matematika siswa kelas VII SMP Negeri 6 Lubuk linggau tahun pelajaran 2015/2016 melalui penerapan model Make A Match secara signifikan tuntas.

Dari uraian diatas dapat penulis simpulkan bahwa karakteristik pembelajaran SD kelas awal adalah pembelajaran yang bersifat konkrit yaitu pembelajaran yang dilaksanakan secara logis dan sistematik untuk membelajarkan siswa yang berhubungan dengan fakta dan kejadian di lingkungan sekitar siswa. Hal tersebut diupayakan untuk pencapaian proses dan hasil pembelajaran yang berkualitas dan lebih bermakna dan sesuai dengan tahap perkembangan siswa.

Mengacu pada penjelasan dan hasil pemikiran di atas, maka pembelajaran yang melibatkan siswa secara aktif, kreatif, dan menyenangkan perlu diterapkan sebagai solusi dari kesenjangan yang ada. Sebagai solusi terhadap hal tersebut, maka penulis mengadakan penelitian tindakan kelas dengan judul "Penerapan model Pembelajaran Make A Match untuk Meningkatkan Hasil Belajar Matematika tentang Pembagian pada Siswa Kelas II SD Muhammadiyah 4 Batu". Penelitian ini bertujuan untuk mengetahui bagaimana penerapan model pembelajaran Make A Match dapat meningkatkan hasil belajar matematika siswa kelas II SD Muhammadiyah 4 Batu.
Menurut Joyce \& Weil, 1980:1 (dalam Rusman, 2012:133) berpendapat bahwa model pembelajaran adalah suatu rencana atau pola yang dapat digunakan untuk membentuk kurikulum (rencana pembelajaran jangka panjang), merancang bahan-bahan pembelajaran dan membimbing pembelajaran di kelas atau yang lain. Model Pembelajaran dapat dijadikan pola pilihan, artinya para guru boleh memilih model pembelajaran yang sesuai dan efesien untuk mencapai tujuan pendidikannya.

Suyatno (2009:72) mengungkapkan bahwa model make and match adalah model pembelajaran dimana guru menyiapkan kartu yang berisi soal atau permasalahan dan menyiapkan kartu jawaban kemudian siswa mencari pasangan kartunya. Model pembelajaran make and match merupakan bagian dari pembelajaran kooperatif. Model make and match melatih siswa untuk memiliki sikap sosial yang baik dan melatih kemampuan siswa dalam bekerja sama disamping melatih kecepatan berfikir siswa.

Model pembelajaran make and match adalah salah satu model pembelajaran yang berorientasi pada permainan.

Menurut Suyatno (2009:102) Prinsipprinsip model make and match antara lain : (1) Anak belajar melalui berbuat (2) Anak belajar melalui panca indera (3) Anak belajar melalui Bahasa (4) Anak belajar melalui bergerak. Tujuan dari pembelajaran dengan model make and match adalah untuk melatih peserta didik agar lebih cermat dan lebih kuat pemahamannya terhadap suatu materi pokok.

Model pembelajaran make and match merupakan model yang menciptakan hubungan baik antara guru dan siswa. 
Guru mengajak siswa bersenang-senang dalam permainan. Kesenangan tersebut juga dapat mengenai materi dan siswa dapat belajar secara langsung maupun tidak langsung.

Adapun langkah-langkah model pembelajaran Make $A$ Match sebagai berikut:

a. Guru menyiapkan beberapa kartu yang berisi beberapa konsep atau topik yang sesuai dengan materi, satu bagian kartu soal dan bagian lainnya kartu jawaban.

b. Setiap siswa mendapatkan sebuah kartu yang bertuliskan soal/jawaban

c. Tiap siswa memikirkan jawaban/soal dari kartu yang dipegang.

d. Setiap siswa mencari pasangan kartu yang cocok dengan kartunya.

e. Setiap siswa yang dapat mencocokkan kartunya sebelum batas waktu diberi poin.

f. Jika siswa tidak dapat mencocokkan kartunya dengan kartu temannya (tidak dapat menemukan kartu soal atau kartu jawaban) akan mendapatkan hukuman, yang telah disepakati bersama.

g. Setelah satu babak, kartu dikocok lagi agar tiap siswa mendapat kartu yang berbeda dari sebelumnya, demikian seterusnya.

h. Guru bersama-sama dengan siswa membuat kesimpulan terhadap materi pelajaran. Model ini membutuhkan waktu lebih untuk permainan mencocokkan kartu dan membahasnya satu persatu dan menarik kesimpulan.

\section{METODE}

Jenis penelitian yang dilakukan ini merupakan penelitian tindakan kelas (classroom action research), yaitu suatu bentuk kajian yang bersifat reflektif dan dilakukan oleh guru dalam mengatasi permasalahan yang dialami dalam proses pembelajaran dari pengalaman belajarnya guna mendapatkan adanya perbaikan dan peningkatan hasil yang ingin dicapai agar lebih baik dari pembelajaran yang telah dilakukan sebelumnya. Adapun subjek penelitian pada penelitian ini adalah siswa kelas II SD Muhammadiyah 4 Batu yang berjumlah 33 siswa terdiri dari 16 siswa laki-laki dan 17 siswa perempuan. Penelitian Tindakan Kelas ini dilakukan dalam 2 siklus. Pada setiap siklusnya dilakukan: perencanaan, tindakan, pengamatan dan refleksi.

Dalam penelitian ini pengumpulan data dilakukan dengan cara: (1) Observasi dan (2) Refleksi awal. Pada umumnya Observasi adalah tindakan yang merupakan penafsiran dari teori, seperti yang dikemukakan oleh Karl Popper (Hopkins, 1993:77 dalam Wiraatmadja 104). Dalam penelitian ini yang di observasi adalah guru dan siswa. Pada Kegiatan Refleksi awal dilakukan kegiatan sebagai berikut:

a) Merencanakan dan melakukan Tes Tertulis, untuk mengetahui hasil belajar siswa.

b) Dokumentasi berupa foto-foto kegiatan pembelajaran selama penelitian berlangsung.

c) Melakukan pengamatan terhadap proses pembelajaran yang sedang berlangsung dan melakukan penilaian terhadap hasil belajar yang dikerjakan siswa secara kelompok dan tugas individu.

d) Nilai hasil belajar, dokumen nilai siswa 2 tahun terakhir.

Data penelitian ini dikumpulkan dengan menggunakan 5 macam instrumen yaitu: a.Lembar observasi Proses Belajar Siswa b) Lembar Observasi Guru c) Lembar angket d) Lembar Kerja Siswa e) Lembar Dokumentasi 
Analisis yang dilakukan terhadap data yang diperoleh dengan teknik deskriptif kualitatif berdasar hasil observasi terhadap pemahaman dan hasil belajar siswa. Data tentang kualitas proses pembelajaran dianalisis secara kualitatif berdasarkan catatan-catatan di lapangan dan hasil observasi dengan analisis distribusi frekwensi dan analisis rata-rata.

Tabel 1. Tahap Penguasaan Kemampuan

\begin{tabular}{llll}
\hline Rentang Nilai & Kriteria & $\begin{array}{l}\text { Taraf Kemampuan } \\
\text { /Ketuntasan(\%) }\end{array}$ & Keterangan \\
\hline $85-100$ & Tinggi & $85,0 \%-100 \%$ & Berhasil \\
\hline $65-80$ & Sedang & $65,0 \%-80,0 \%$ & Kurang Berhasil \\
\hline $45-60$ & Rendah & $45,50 \%-60,0 \%$ & Tidak Berhasil \\
\hline
\end{tabular}

\section{HASIL DAN PEMBAHASAN}

\section{Siklus I}

Pada siklus ini fokus materi yang diberikan adalah tentang pasangan bilangan pembagian yang hasil baginya diketahui dengan Model Pembelajaran Make A Match dengan menggunakan kartu soal pembagian dan kartu jawaban pembagian. Kegiatan yang dilakukan meliputi :

1) Perencanaan (Planning)

a) Membuat RPP dengan standar kompetensi dan kompetensi dasar yang diharapkan dapat dicapai siswa.

b) Menyiapkan bahan dan media pembelajaran yang digunakan dalam penelitian, yaitu: Kartu soal pembagian dan Kartu jawaban pembagian

c) Membagi siswa dalam 6 kelompok, masing-masing kelompok terdiri dari 4-6 siswa.

d) Membicarakan rencana tindakan pada siswa dan kolabolator.

2) Tindakan (Acting) :

a) Melaksanakan perencanaan Siklus I. Dalam Pelaksanaan siklus I ini guru menyelesaikan permasalahan secara klasikal, dengan mendemontrasikan model pembelajaran Make A Match dan menggunakan media kartu soal pembagian dan kartu jawaban pembagian.

b) Penugasan siswa dilakukan secara berkelompok dengan bermain kartu soal pembagian dan kartu jawaban pembagian.

c) Dalam setiap kelompok siswa mencari pasangan kartu soal dan mencocokkannya dengan kartu jawaban.

d) 1-2 siswa mempresentasikan hasil kerja kelompok, dan kelompok lain memberikan tanggapan

3) Pengamatan (Observing) :

Peneliti melakukan observasi terhadap tindakan yang dilakukannya dengan menggunakan lembar observasi dengan dibantu oleh kolaborator. Dari lembar observasi ini peneliti dapat mengukur keberhasilannya. Kegiatan Pengamatan meliputi :

a) Pembelajaran yang dilakukan oleh guru sebagai peneliti ketika mendemontrasikan model pembelajaran Make A Match menggunakan media kartu soal pembagian dan kartu jawaban pembagian. Pengamatan dilakukan oleh kolabolator. 
b) Perilaku dan aktifitas siswa terhadap pembelajaran yang dilakukan yaitu keaktifan siswa dalam bermain kartu soal dan kartu jawab. Sebagai pengamat dilakukan oleh peneliti dan kolabolator.

c) Perhatian dan antusiasme siswa ketika bermain dalam kelompok dan mengerjakan tugas individu serta mempresentasikan hasil kerja kerjanya. Pengamatan dilakukan oleh peneliti dan kolabolator.

4) Refleksi (reflecting)

Refleksi dilakukan ketika pembelajaran telah selesai dilaksanakan. Hal-hal yang direfleksikaan meliputi semua hasil pengamatan yang dilakukan oleh peneliti dan kolabolator. Hasil refleksi pada siklus I ini digunakan untuk menentukan tindakan pada siklus selanjurtnya.

\section{Siklus II}

Berdasarkan hasil tindakan, pengamatan dan Refleksi yang telah dilaksanakan pada Siklus I, dilakukan perancangan penyempurnaan terhadap Siklus II, yaitu mendemontrasikan model pembelajaran Make A Match dengan memodifikasi cara menentukan pasangan bilangan pembagian dengan media kartu soal pembagian dan kartu jawaban pembagian dalam hal menambah jumlah kartu jawaban yang salah/bukan merupakan jawaban dari kartu soal pembagian. Dan memodifikasi bentuk soal sesuai dengan kartu soal dan kartu jawab. Pelaksanaan Siklus II dilakukan seperti pada tahap Siklus I yaitu mulai dari perencanaan, pelaksanaan, pengamatan, dan refleksi.

Model pembelajaran Make A Match adalah model pembelajaran kooperatif yang mengutamakan kemampuan sosial terutama kemampuan bekerja sama dan berinteraksi dalam kelompok, yang dilakukan melalui permainan dengan menggunakan kartu soal dan kartu jawaban. Adapun salah satu keunggulan dari model pembelajaran Make A Match yaitu siswa mencari pasangan kartu soal dan kartu jawaban sambil belajar mengenai suatu konsep atau topik dalam suasana yang menyenangkan.

Hasil belajar siswa pada siklus I dan siklus II dapat dilihat pada tabel 1 berikut :

Tabel 1 Rerata Hasil Tes Siklus I dan Siklus II

\begin{tabular}{llcc}
\hline No & Tindakan & Rerata & Persentase \\
\hline 1 & Pra Siklus & 56,8 & $57 \%$ \\
2 & Siklus I & 77,8 & $78 \%$ \\
3 & Siklus II & 92,5 & $93 \%$ \\
\hline
\end{tabular}

Berdasarkan nilai yang diperoleh dari hasil tes Siklus I diketahui bahwa dari jumlah siswa yang mengikuti tes, sebanyak 17 dari 30 siswa yang mencapai KKM sedangkan 13 siswa masih belum mencapai KKM, sehingga persetase ketuntasan klasikal $56,66 \%$ dan sisanya $43,33 \%$ belum tuntas. Persentase tersebut belum memenuhi ketuntasan belajar klasikal sebaesar $75 \%$. Karena hasil analisis yang diperoleh belum mencapai katagori tersebut, maka penelitian dilanjutkan ke siklus II.

Sedangkan nilai yang diperoleh dari hasil test pada siklus II diketahui bahwa dari jumlah 32 siswa sebanyak 28 siswa sudah mencapai di atas KKM sedangkan 4 siswa mesih belum mencapai KKM sehingga persentase ketuntasan klasikal $87,5 \%$ tuntas dan sisanya $22,5 \%$ belum tuntas. Persentase tersebut sudah memenuhi bahkan melampaui ketuntasan belajar secara klasikal. Hasil belajar siswa meningkat signifikan. 
Analisis data mengenai hasil belajar siswa dilakukan dengan menghitung jumlah siswa yang telah tuntas belajar dari post test yang telah dilakukan dengan materi menentukan pasangan bilangan pembagian yang hasil baginya diketahui.

Meskipun data yang diperoleh pada siklus I rerata hasil belajar 77,8 bila dipersentase $78 \%$ sudah diatas KKM, namun peneliti menginginkan ada peningkatan yang lebih signifikan sehingga dilanjutkan dengan pelaksanaan siklus II.
Pada pelaksanaan proses pembelajaran siklus II rerata hasil belajar siswa yaitu 92,5 bila dipersentase $93 \%$ sudah di atas KKM, tampak adanya peningkatan yang signifikan dan melampaui target KKM yang sudah ditentukan.

Hasil pengamatan observasi hasil tes, ketuntasan belajar dari tindakan siklus I dan II dapat dilihat pada tabel 2 berikut :

Tabel 2 ketuntasan belajar

\begin{tabular}{clcccc}
\hline \multirow{2}{*}{ No. } & \multirow{2}{*}{ Tindakan } & \multicolumn{2}{c}{ Banyak Siswa } & \multicolumn{2}{c}{ Persentase } \\
\cline { 3 - 6 } & & CKKM & $>$ KKM & $<$ KKM & $>$ KKM \\
\hline & Pra & & & & \\
1 & Siklus & 23 & 9 & $71,9 \%$ & $28,1 \%$ \\
\hline 2 & Siklus I & 17 & 13 & $43,3 \%$ & $56,7 \%$ \\
\hline 3 & Siklus II & 4 & 28 & $22,5 \%$ & $87,5 \%$ \\
\hline
\end{tabular}

Dari tabel 1 di atas dapat diperoleh data sebagai berikut :

Pra Siklus : a) siswa yang $<\mathrm{KKM}$ adalah 23 siswa dengan persentase $72 \%$

b) siswa yang $>$ KKM adalah 9 siswa dengan persentase $28 \%$

Siklus I: a) siswa yang $<$ KKM adalah 17 siswa dengan persentase $44 \%$

b) siswa yang $>\mathrm{KKM}$ adalah 13 siswa dengaan persentase $56 \%$

Siklus II : a) siswa yang $<$ KKM adalah 4 siswa dengan persentase $22 \%$

b) siswa yang $>\mathrm{KKM}$ adalah 28 siswa dengan persentase $88 \%$
Berdasarkan hasil penelitian di atas, dapat disimpulkan bahwa Model pembelajaran Make A Match adalah model pembelajaran kooperatif yang mengutamakan kemampuan sosial terutama kemampuan bekerja sama dan berinteraksi dalam kelompok, yang dilakukan melalui permainan dengan menggunakan kartu soal dan kartu jawaban. Adapun salah satu keunggulan dari model pembelajaran Make A Match yaitu siswa mencari pasangan kartu soal dan kartu jawaban sambil belajar mengenai suatu konsep atau topik dalam suasana yang menyenangkan.

Sebagaimana disampaikan oleh Rusman (2012), bahwa Salah satu cara keunggulan teknik Make A Match ini adalah peserta didik mencari pasangan sambil belajar mengenai suatu konsep atau topik, dalam suasana yang menyenangkan. 
Anita Lie (2008: 56) menyatakan bahwa model pembelajaran tipe Make A Match atau bertukar pasangan merupakan teknik belajar yang memberi kesempatan siswa untuk bekerja sama dengan orang lain. Teknik ini bisa digunakan dalam semua mata pelajaran dan untuk semua tingkatan usia anak didik.

Miftahul Huda (2013: 253-254) menyatakan bahwa kelebihan model pembelajaran tipe Make A Match antara lain: (1) dapat meningkatkan aktivitas belajar siswa, (2) karena ada unsur permainan, metode ini menyenangkan; (3) meningkatkan pemahaman siswa terhadap materi yang dipelajari dan dapat meningkatkan motivasi belajar siswa; (4) sarana melatih keberanian siswa untuk tampil presentasi; dan (5) melatih kedisiplinan siswa menghargai waktu untuk belajar.

Peningkatan hasil belajar ini disebabkan karena beberapa hal yang mendukung yaitu selain model pembelajaran Make A Match menekankan pada usaha untuk meningkatkan interaksi siswa dan kerjasama dalam pembelajaran, siswa juga lebih aktif dan antusias dalam proses pembelajaran dengan penerapan model pembelajaran Make A Match yang menggunakan kartu soal dan kartu jawaban, dalam hal ini siswa sebagai subjek pembelajar (student centered) sehingga belajar siswa menjadi lebih bermakna.

Selain itu juga peneliti berupaya memodifikasi kartu soal dan latihan soal, dengan demikian siswa memperoleh gambaran konkrit dalam menentukan pasangan bilangan pembagian yang hasil baginya diketahui. Sehingga proses pembelajaran dengan menerapkan model pembelajaran Make A Match terhadap materi pembagian dalam menentukan pasangan bilangan pembagian yang hasil baginya diketahui hasil belajar siswa meningkat sangat signifikan dengan prosentase $87,5 \%$ sudah melampaui target KKM yang ditentukan. Berdasarkan hasil penelitian dan analisis data di atas, dapat disimpulkan bahwa penerapan Model Pembelajaran Make A Match dapat meningkatkan prestasi belajar matematika siswa kelas II tentang pembagian yaitu dalam menentukan pasangan bilangan pembagian yang hasil baginya diketahui.

Berdasarkan hasil pengamatan yang dilakukan oleh observer I dan II, sikap Antusiasme siswa dalam proses pembelajaran dan kemampuan psikomotorik siswa dalam hal aktifitas dan bekerjasama dalam kelompok hasilnya juga masih rendah. Dengan kata lain sikap siswa ditinjau dari antusiasme siswa belum mencapai harapan yang diinginkankan oleh guru dan kemampuan psikomotorik siswa dalam hal aktifitas dan bekerjasama dalam kelompok belum mencapai peningkatan yang signifikan.

Demikian juga dengan konsep pembelajaran yang disajikan oleh guru terkesan tergesa-gesa, sehingga kemampuan siswa dalam memahami materi pembagian masih belum optimal dan belum mencapai hasil yang maksimal.Maka untuk mendapatkan hasil yang lebih maksimal peneliti menganggap perlu untuk melanjutkan pada siklus berikutnya. dengan melakukan beberapa perbaikan tindakan, diantaranya yaitu :

1. Perbaikan pelaksanaan model pembelajaran Make A Match dengan memodifikasi kartu soal dan kartu jawaban.

2. Menambah jumlah kartu jawaban yang salah/ bukan merupakan jawaban dari kartu soal pembagian.

3. Memodifikasi bentuk soal pada LKS sama seperti yang tertera pada kartu soal dan kartu jawaban. 
4. Guru menjelaskan kembali cara bermain kartu soal dan kartu jawaban, dan memperjelas petunjuk kerja cara menyelesaikan LKS, sehingga siswa lebih fokus dan lebih teliti dalam kegiatan tersebut.

Dengan tindakan ini diharapkan siswa yang belum tuntas akan berusaha dapat menguasai materi pelajaran dengan baik, sehingga prestasi belajar siswa dapat meningkat. Dengan melakukan perbaikan tindakan pada siklus II ternyata dapat meningkatkan persentase ketuntasan belajar siswa. Siswa yang dikatakan tuntas secara individu ada 28 siswa dan 4 siswa yang belum tuntas, dengan ketuntasan klasikal $87,5 \%$.

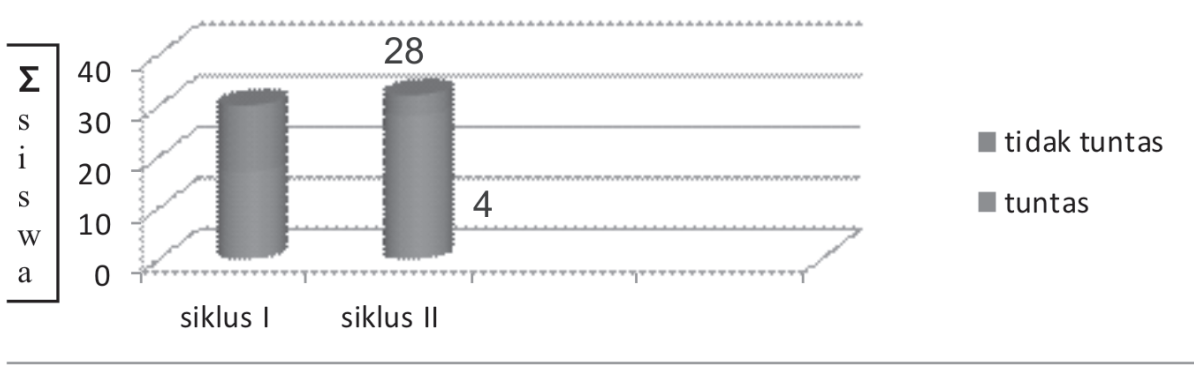

Diagram Pencapaian KKM Siklus I dan Siklus II

Sumber : data primer di olah

Hasil belajar merupakan kemampuan yang diperoleh individu setelah proses belajar berlangsung, yang dapat memberikan perubahan tingkah laku baik pengetahuan, pemahaman, sikap dan keterampilan siswa sehingga menjadi lebih baik dari sebelumnya, sebagaimana yamg dikemukakan Sudjana ( 2005:3 ) " hasil belajar ialah perubahan tingkah laku yang mencakup bidang kognitif, afektif dan psikomotor yang dimiliki siswa setelah menerima pengalaman belajarnya". Hasil penelitian ini menunjukkan bahwa model pembelajaran Make A Match dapat meningkatkan prestasi belajar siswa. Peningkatan hasil belajar matematika siswa dengan menggunakan model Make A Match dapat terlihat dengan peningkatan pencapaian KKM antara siklus I sebesar $56,7 \%$ menjadi $87,5 \%$ pada siklus II, sehingga ada peningkatan sebesar 30,8\%

\section{SIMPULAN}

Berdasarkan hasil penelitian pada proses pembelajaran matematika materi pembagian yang telah dilakukan dengan model pembelajaran Make A Match menggunakan kartu soal dan kartu jawaban, dapat disimpulkan bahwa :

a. Dalam proses pembelajaran matematika dengan model Make A Match, siswa lebih aktif kerjasama antar siswa dalam kelompok terjalin dengan baik.

b. Hasil belajar siswa menunjukkan adanya peningkatan yang sangat signifikan yaitu dari rerata hasil belajar siswa pada siklus I mencapai 77,8 setelah diterapkannya model pembelajaran Make A Match hasil belajar siswa pada siklus II meningkat menjadi 92,5 Hal ini menunjukkan kenaikan rerata hasil belajar yang sangat signifikan.

c. Dalam hal ketuntasan belajar siswa dapat disimpulkan bahwa hasil belajar siswa mencapai $87,5 \%$ dan rerata hasil belajar siswa 92,5sudah di atas KKM yang ditentukan dan diharapkan oleh peneliti, maka penerapan model pembelajaran Make A Match dalam 
pembelajaran matematika materi pembagian berhasil dengan baik.

Penerapan model pembelajaran Make A Match dalam pelajaran matematika terhadap materi pembagian dikelas II ini merupakan salah satu model pembelajaran dari banyak model pembelajaran yang ada. Model pembelajaran Make A Match bukan merupakan satu-satunya model pembelajaran yang terbaik.Namun model pembelajaran Make A Match ini bisa diterapkan untuk disajikan dalam proses pembelajaran terhadap kompetensi dasar yang lain dalam mata pelajaran matematika atau mata pelajaran yang lainnya.

Untuk meningkatkan profesionalitas guru dan meningkatkan kualitas pembelajaran diperlukan adanya kreatifitas guru untuk memilih dan menggunakan model-model pembelajaran yang sesuai dengan materi pembelajaran mata pelajaran matematika atau mata pelajaran yang lain. Untuk memperoleh peningkatan kualitas hasil pembelajaran dan peningkatan prestasi siswa, sebaiknya jika dilakukan penelitian ulang di sekolah yang berbeda dengan subyek didik yang berbeda pula.

\section{DAFTAR PUSTAKA}

Anita Lie. 2008. Cooperative Learning Mempraktikan Cooperative Learning di Ruang-Ruang Kelas. Jakarta: PT Gramedia.

Mihtahul Huda. 2013. Model-model Pengajaran dan Pembelajaran. Yogyakarta: Pustaka Pelajar.

Monalini. 2016. Penerapan Model Make A Match Pada Pembelajaran Matematika

Siswa Kelas VII SMP Negeri 6 Lubuklinggau Tahun Pelajaran 2015/2016; Skripsi, STKIP Lubuk Linggau
Rusman.2012. Model-Model Pembelajaran Mengembangkan Profesionalisme Guru. Jakarta: Raja Grafindo Persada

Sudjana, N. 2005. Penilaian Hasil Proses Belajar Mengajar, Bandung: PT. Remaja Rosdikarya.

Sudjana. 2005. Metode Statistika Edisi ke-6. Tarsito. Bandung.

Suryadi, Didi, 2007. Pendidikan Matematika. Dalam Ali, M, ibrahim, R, Sukmadinata,N.S., Sudjana, D., dan rasjidin, W (Penyunting). Ilmu dan Aplikasi Pendidikan. Bandung: Pedagogiana Press

Suyatno, 2009. Menjelajah Pembelajaran Inovatif. Sidoarjo: Masmedia Buana Pustaka

Wiriaatmadja, Rochiati, 2008. Metode Peneltian Tindakan Kelas. Bandung: Remaja Rosdakarya 


\title{
IMPLEMENTATION OF 2015 MENTORING PROGRAM IN ENGLISH DEPARTMENT OF UNIVERSITY MUHAMMADIYAH MALANG
}

\author{
Nina Inayati, Laela Hikmah Nurbatra, Rahmawati Khadijah Maro \\ FKIP Universitas Muhammadiyah Malang \\ Email: nurbatra@yahoo.com
}

\begin{abstract}
The Mentoring Program of the English Department of UMM is an extra-curricular program designed to assist first year students to practice their English speaking and independent study. The speaking skills are focused on two specific skills; presentation and debate skills; while the English independent study introduces students to various English learning activities students could potentially integrate in their daily lives. The current study employs document analysis and survey as the methods of data collection. Then, content analysis is used to identify the salient themes and patterns occurring from the data to be presented based on the research problems. Analysis of the data shows that the program ran as planned and that some mentors developed the prepared lesson plans. As for the program evaluation, analysis of the survey results show that, in general, the program was viewed positively by the students. Some strengths mentioned were that the module was helpful and informative and that the mentors were fun and motivating. As for the weaknesses, Saturday morning schedule was considered bad option and that outdoor venues were less conducive some times. In light of the evaluation, some suggestions for the future program are offered, such as to improve the timing and venues.
\end{abstract}

Key words: Mentoring, English Language Learning, Speaking, Independent Study

\section{INTRODUCTION}

The English Department of the University of Muhammadiyah Malang (UMM) as one of the leading and popular departments is continuously striving to improve its excellence in teaching in order to produce quality outcome. One of the attempts to do that is by actively participating in various inter-university cooperations both nationally and internationally. On the 4-7 Janury 2015, the English Department of UMM sent three delegates to attend the Workshop on Curriculum Development organized by Majelis Pendidikan Tinggi PP Muhammadiyah in the University of Muhammadiyah Yogyakarta. The workshop was in cooperation with the
Temasek Foundation-a non-profit organization based in Singapore which main focus is to promote networking and cooperation among communities in Asia-and the National University of Singapore (NUS). One of the insights gained from the workshop was the need to strengthten the English language foundation of new students and to minimize the proficiency gap among them. After some consultation with the board of leaders of the department, it was decided to follow up the workshop with a new program for the first year students called the Mentoring Program.

The Mentoring Program of the English Department of UMM is an extra-curricular program designed to 
assist first year students to practice their English speaking and independent study. Both aspects become the main foci of the program due to the need to build students' positive attitudes towards English learning and to forge their confidence in using English in their daily lives. The speaking skills are focused on two specific skills; presentation and debate skills; while the English independent study covers the introduction to various English learning activities students could potentially integrate in their daily lives. By attempting to informally integrate English learning in their daily lives through speaking and independent study, it is expected that the rich exposure to the language could assist in strengthening the students' English proficiency to be later reinforced in the formal classroom instructional settings, thus improving the quality of learning outcome altogether.

The informal setting of Mentoring Program is achieved by involving senior students as mentors for the first-year student mentees. Each mentor is responsible to tutor ten to twelve mentees during eight mentoring sessions held every Saturday morning in either outdoor or indoor classroom settings. The mentors are students of the fourth to eight semester who are considered highly proficient in speaking English as well as in tutoring their juniors. They were equipped with workshop for mentors, mentoring handout and lesson plans for each mentoring session. In addition, they are also assigned a lecturer-supervisor to guide them with any practical issues and are supported with a biweekly evaluation meeting for mentors to observe the progress of the program and to ensure the program runs effectively and efficiently.
As this first program is planned to be the pioneer for the next mentoring projects, it is considered necessary to study its execution in order to be able to systematically analyze how the program run as well as its strengths and weaknesses. The insights gained are expected to assist in improving the organization of the next mentoring programs to achieve maximum results for the students, the English Department as well as the university in general.

\section{Mentoring}

Mentoring literally refers to the activity of helping and giving advice or supervision to younger or less experienced person, especially related to working or studying (Cambridge Dictionaries Online, 2015). Literature document a relatively high number of studies on mentoring within the area of company management, particularly those related to the training of new employees. In the education realm, especially in the field of English Language Teaching (ELT), mentoring has been moderately documented in the area of English teaching practice supervisory (Kullman, 1998; Arnold, 2006; Balassa, Bodo'czky and Saunders, 2010), which can be argued to have the same spirit of the company's version of mentoring; the training of the novice teachers by the more experienced teachers. Using the same underlying definition of aforementioned mentoring, the current study offers a slightly different version of mentoring involving more experienced senior students as the mentors in learning English and the relatively less experienced first-year students of the same major as the mentees.

In other words, the mentoring program in this study refers to the systematic activity of assisting first-year 
students of English Department of the University of Muhammadiyah Malang (UMM) as the relatively novice learners of the language by their seniors who are comparatively more experienced. As suggested by Kullman (1998), mentors are advised to play a 'non-directive, developmental and collaborative' roles which includes assisting mentees' overall development by providing necessary guidance, feedback and building positive personal attitude and beliefs towards learning through reflection activity. Adopting Arnold's (2006) standard for quality outcome in mentoring, the activity should result in mentees' improved skills in learning, as well as deeper reflection skill which leads mentees to grow personally in 'self-image, self-esteem, and selfconfidence', especially in terms of their English Language skills.

Based on the results of preliminary observation and reflection by the English Department lecturers of UMM, the current mentoring program covers three main foci which become the major concerns among students, they are the students' attitudes towards learning English independently and the speaking skills focusing on presentating and debating skills. Therefore, the following discussion of the literature are directed towards the three mentoring foci-English independent study, presentation skills and debating skills.

\section{English Independent Study}

Rooted in the notion of autonomous learning, English Independent Study (EIS) expects learners to take responsibility of their own learning. This is in line with Smith's (2008) definition of autonomous learning, which is individual's capacity to be in charge of their own learning.
Furthermore, learning takes place in the learner's mind (Crabbe, 1993), therefore, it may happen anywhere and anytime. In terms of additional language learning, Crabbe further pinpoints that its success depends heavily on how well learners could use various learning opportunities at their immediate disposal, whether it is inside or outside the classroom settings. In practical sense, EIS requires learners to find and/ or create their own English learning exposure in order to maximize the opportunities for language acquisition (Inayati, 2015). Consequently, it is expected that they are also equipped with strategies to learn the language beyond the classroom boundaries (Krashen, 1982).

Independence in learning has often been associated with successful language learning. Yanren (2007), studying successful Chinese learners who won a number of national English speaking and debate competitions, reported that they spent a huge amount of time learning English independently from frequent watching of English language movies and reading books of their favorite. In addition, Wong and Nunan (2011) found that their Hong Kong-based students who scored highly on a nationally standardized English examination reported that they spent longer time studying and practicing their English independently outside the classroom compared to those who scored low in the examination.

Considering the threories and previous studies above, EIS was implemented as part of the mentoring program in order build students' awareness and positive attitude towards independent learning, which eventually is expected to enlarge their opportunity of success in learning English. Its implementation is started with some 
discussion about the nature of EIS followed by brainstorming of ideas about potential English exposure available around their immediate environment. Then, it is followed by real weekly practice of how to use those exposures into students' learning advantages in the form of independent study. Their learning experience is then shared in the class in order to see the progress and clarify some lack of understanding on the students' part. This technique of independent study training has proven to be effective in terms of its sustainability as reported by Inayati (2015). Studying two Indonesian-based cohorts of English learners, she found that after 12 weeks of such training, the students reported positive perception and continuity of some EIS activities by the students even months after the training finished.

According to Inayati (2015), there are some principles of EIS such as rich exposure to English, learners' freedom to choose their own learning materials, comprehensible and balanced language input and output, and using various EIS strategies. Adopting such principles, the indicators of success for EIS in this mentoring program is set as follows; first, students can identify potential English exposure in their immediate environment; and second, students can do various EIS activities in accordance with the principles of EIS.

\section{Presentation Skills}

As one of the productive skills, speaking is considered a difficult skill to master. One of activities in speaking skill is oral presentation. For EFL learners, oral presentation is a complex skill, as it requires cognitive and sociolinguistic understanding (Adams, 2004, in Yu \&
Cadman, 2009). In this skill, learners are expected not only to understand the material that they present, but also to have grammar and communication competences (Yu \& Cadman, 2009). It means that EFL learners need to be aware of complicated aspects in oral presentation.

Furthermore, given that successful L2 learners can be identified from his or her ability to speak in different situations (Roger, 2008, in Yahay \& Kheirzadeh, 2015), it is important for learners to be given opportunities to practice more comprehensively. This is supported by the findings of Ferris (1998, in Yahay \& Kheirzadeh, 2015) who investigated ESL students in American institutes. He mentioned that oral presentation and discussion is one area that the students were highly concerned; however, they were also aware that they should have been given more opportunities for the activities.

From those perpectives, presentation is highlighted as one of important activities in the mentoring program. Although language learners are responsible for the progress that they went through (Yahay \& Kheirzadeh, 2015), English Department in UMM needs to make sure that the students are provided with adequate exposure to practice using the language. Initially, interesting brainstorming activities such as playing crossword puzzle, or small discussion on certain topics is conducted to famialiarise the students with the context. By the time they are familiar with the vocabulary and the language expression they need in presenting about certain issue, the students are expected to have oral presentation either individually, in pairs, or even in groups.

A successful oral presentation can be assessed from various criteria. In this context, there are six elements to consider 
in assessing presentation skill. These criteria are content and analysis, structure, equity, non-verbal, verbal and visual aids. These elements are adopted from the criteria sheet oral presentation used by Cooper (2005). The first element, content and analysis, deals with the content of the presentation that needs to have clear concept. While structure, as the second element, focus on the logical order of the presentation, which needs to be delivered within the time frame. Thirdly, equity is the contribution as the team member in terms of the research and the delivery. The fourth criterion is in regards with non verbal, which identify the body language and gesture during the presentation. On the other hand, verbal as the fifth element focus on the words that are pronounced during the presentation. As the last element, visual aid, oral presentation will be assessed from the visual aids used and the conceptual link with the topic.

\section{Debating Skills}

Speaking is "the process of building and sharing meaning through the use of verbal and non-verbal symbols, in a variety of contexts" (Chaney and Burk, 1998, p. 13). Speaking is a crucial part of second language learning and teaching. Today's world requires that the goal of teaching speaking should improve students' communicative skills, because that is how students can express themselves and learn how to follow the social and cultural rules appropriate in each communicative circumstance. Therefore, recent pedagogical research on teaching students conversation has provided some parameters for developing objectives and techniques; one of which is through the use of debate.
Debate is a formal, systematic and structured way of discussing a topic. In speaking, a debate usually involves two teams; the affirmative and the negative teams (Quinn, 2005). The affirmative team is required to argue that certain debate topic is true; while the negative team needs to argue otherwise. Each team should use two basic types of argument to support their stand; the substantive argument which is prepared in favour of a team's side of the topic and the rebuttal argument which attacks the opposition's arguments.

The systematic nature of debate is believed to allow learners to be more argumentative and logical in their speaking, thus training their practical communicative skills. Therefore, debating skills is used as one of the foci in the mentoring program since the students of English Department of UMM are expected to be able to speak in a systematic, argumentative, and logical manner in English; thus, giving them the basics of debate is considered necessary.

There are some elements to consider in scoring debate. In detail, there are ten aspects to be analysed in assessing debate such as appearance of team or seriousness of team, delivery, opening assessment, member participation, arguments, rebuttal, team member participation in rebuttal, summary, answer to the audience questions and respects.

\section{METHOD}

The researcher used descriptive research design to analyse the mentoring program administered by the English Department, University of Muhammadiyah Malang. Descriptive study is chosen because the researcher intended to investigate the actual setting and execution of the program. 
The subjects of this study consist of three different roles in mentoring program. First, the study involves mentees as the core subject of the program. Secondly, it includes mentors as one of the crucial components of the program. Lastly, it also involves supervisors who provided close guidance for the mentors to run the program. All these components of mentoring program are going to be systematically studied in order to gain insights about the project.

With regards to the instruments used, the current study uses document analysis from the mentoring program in the form of handout book, lesson plans of each meeting, and mentors' journal to observe the implementation of the program. In addition, data about the strengths and weaknesses of the program was observed using an open survey. In the survey administered at the end of the program, the mentors and mentees are requested to evaluate the positive and negative aspects of the program in terms of the time, venue, module, and mentors/mentees.

In analyzing the data, the researchers employ content analysis to find the occurring salient themes and patterns of the data classified based on the research problems.

\section{FINDINGS}

\section{The Implementation of 2015 Mentoring Program}

The implementation of the 2015 mentoring program were observed from the documents used, which were the mentoring handout book, lesson plans, and mentors journals. The analysis results is presented based on the aspects of time and venue, module, mentors, mentees, supervisors, mentoring agenda, and the lesson plans.

\section{Time and Venue}

The program was held every Saturday from 11 April 2015 to 6 June 2015 at 8-10 am. The program was intended to be conducted outdoor in the gazebos around campus area in the hope to create semi formal atmosphere during mentoring sessions. However, since there were not enough conducive outdoor spaces, 5 of the 20 mentoring groups were conducted indoor. Interestingly, during the mentoring program 2015, mentors, mentees and supervisors wears the same outfit, a uniform of red t-shirt.

\section{Module}

In terms of materials in mentoring program, a module is prepared differently for mentor and mentees. Module for mentors consists of all the materials needed in the program enclosed with the schedule, lesson plan and evaluation rubric. On the other hand, module for mentees only consists of materials for mentoring program. The module covers eight handouts for eight meetings with three core activities that are highlighted in the program, such as independent study, presentation and debate. Story telling is added in the module as one of activity to challenge the students' competence in using English in oral form. Despite the creativity that is expected from the mentor in using the module, it is used as guidance so that the program meet the expected results based on the designed schedule.

\section{Mentors}

Mentors play significant role in the implementation of mentoring program. They are senior students of English Department who were selected based on their skill, attitude and commitment. The selection process was done on $28 \mathrm{March}$ 
2015 by interviewing the applicants in order to know their English skill, particularly speaking skill. Moreover, the interview in the selection process is used to know the candidates' attitude and commitment on the mentoring program. 24 mentors were selected out of 38 applicants and were trained before the program was held. The training was conducted on 30 March 2015 and it was aimed to prepare the mentors for the program. For that reason, the training emphasizes on building the mentors' understanding towards the program and all the related matters such as module, activities, media and evaluation.

Mentors involved in the 2015 mentoring program are highly committed as they prepare, organize and run mentoring session every week. One or two mentors were assigned to be in charge in one group. The purpose for this is to build strong connection between mentors and mentees. Before the session, mentors are expected to prepare themselves by comprehending materials and lesson plans provided in the module for mentors. If they had any difficulties about materials or lesson plan, they could ask their supervisors or committee. Although materials and lesson plan had been provided, mentors could express their creativity in terms of additional materials or activities in the session. As long as the objectives of the session were achieved, mentors were free to adjust the session based on their own way.

During the session, mentors were responsible in running the program. In 100 minutes session, they assisted students in participating in the program. Not only as teacher who guide the students in learning, they also played the roles as friends who can share their thoughts freely.

\section{Mentees}

All semester 2 students were registered in the 2015 mentoring program that were divided into 20 groups of 10-12 students. The classification was based on the class that they regularly attended for lecture. In general, there were four groups in a class, which were randomly classified. This had lead to the variety of students' English proficiency in one group. The varied level of English skill proficiency of the students was indicated from the students who come from different areas in the country. Students who had adequate English background possessed different English proficiency level with students from remote areas in Indonesia. This was recognized as one of the challenges in mentoring program, as the program need to suit the students with variety of English proficiency. Furthermore, given that mentees were second-semester students who registered themselves for the program, most of them did not have adequate confidence in using English in oral communication. Although they understood English to some level, it was not easy for these students to use English in spoken form. One of the reasons for this was because they had limited opportunities to use English as their communication tools, and they were too shy to speak in English.

\section{Supervisors}

Supervisors are selected lecturers of English Department of University of Muhammadiyah Malang who are responsible in assisting the mentors and evaluate the program. There were 10 supervisors involved to support the 2015 mentoring program. Each supervisor in mentoring program was in charge for two groups with two to four mentors. If the 
mentors had any difficulties about the program, supervisors were to discuss with. In addition, supervisors were responsible to monitor the mentoring session so that they could give feedback on how the mentors run the session. Some problems with supervisors' active involvement were found during the mentoring sessions. Some supervisors were actively involved and there were a few of them who were lacking in involvement. To deal with the problem, biweekly evaluation was offered to provide more equal assistance for all mentors.

\section{Mentoring Program Agenda}

The 2015 mentoring program was conducted in eight weeks based on the objective of the program. Below is the timetable of the program:

\section{Table 1. The Weekly Agenda of 2015 Mentoring Program}

\begin{tabular}{|c|c|c|}
\hline MEETING & TOPICS & GOALS \\
\hline I & $\begin{array}{l}\text { English Independent Study } \\
\text { Introduction to EIS } \\
\text { Discussing potential } \\
\text { activities }\end{array}$ & $\begin{array}{l}\text { Creating a solid basis for students to } \\
\text { independently try to find/ create their own } \\
\text { exposure for maximum English acquisition }\end{array}$ \\
\hline II & $\begin{array}{l}\text { English Independent Study } \\
\text { Sharing about EIS } \\
\text { experience }\end{array}$ & $\begin{array}{l}\text { Sharing and clarifying students' } \\
\text { implementation of EIS to iron out potential } \\
\text { misunderstanding and misperception. }\end{array}$ \\
\hline III & $\begin{array}{l}\text { Presenting } \\
\text { Comparison } \\
\text { Discussion } \\
\text { British vs American English }\end{array}$ & $\begin{array}{l}\text { Students state their opinions } \\
\text { Analyzing and discussing differences and } \\
\text { similarities }\end{array}$ \\
\hline IV & $\begin{array}{l}\text { Presenting } \\
\text { Discussion } \\
\text { Useful phrases } \\
\text { Stress Management }\end{array}$ & $\begin{array}{l}\text { Students are able to use phrases in discussion } \\
\text { and engage in problem solving activities. }\end{array}$ \\
\hline V & $\begin{array}{l}\text { Presenting } \\
\text { Pecha Kucha presentation } \\
\text { Question and Answer } \\
\text { Invention }\end{array}$ & $\begin{array}{l}\text { Students present their topics and answer } \\
\text { questions. } \\
\text { Mentor and students provide feedback in terms } \\
\text { of presenting skills. }\end{array}$ \\
\hline VI & $\begin{array}{l}\text { Telling Story } \\
\text { Sharing tips of storytelling } \\
\text { Practicing telling stories }\end{array}$ & $\begin{array}{l}\text { Students discuss about tips of storytelling and } \\
\text { practice telling stories in an engaging manner. }\end{array}$ \\
\hline VII & $\begin{array}{l}\text { Debate } \\
\text { Introduction to debate } \\
\text { Designing argumentation }\end{array}$ & $\begin{array}{l}\text { Students discuss about the nature of debate and } \\
\text { what makes a good debater. } \\
\text { Students practice to design argumentation } \\
\text { statement }\end{array}$ \\
\hline VIII & $\begin{array}{l}\text { Debate } \\
\text { Preparing argumentation } \\
\text { technique } \\
\text { Persuasive and role } \\
\text { description } \\
\text { Debate practice }\end{array}$ & $\begin{array}{l}\text { Students practice to present argumentation } \\
\text { statement } \\
\text { Students understand the role of team debating } \\
\text { member } \\
\text { Students practice to have debate battle }\end{array}$ \\
\hline
\end{tabular}




\section{Lesson Plan}

Lesson plan in the mentoring program was designed to help mentors to run the session. The lesson plan was enclosed in the module for mentors for each activity in the module. As has been previously stated, the lesson plan was not the only way for the mentors to apply in the session as mentors could improve and develop the teaching plan as creative as possible. The lesson plans were used as the guidance so that the objective of the program is achieved. As the consequence, mentor were allowed to adjust the methods or media used. Analysis of the mentors' journal shows that some mentors developed the prepared lesson plans by, for example, adding games and inserting music and movies in the activities. The example of lesson plans in the 2015 mentoring program could be examined as follows:

Sample of lesson plan used for the 2015 mentoring session

\begin{tabular}{lll}
\hline Faculty/ Department & $:$ & FKIP/ English Education \\
\hline Course/ Program & $:$ & Mentoring \\
\hline Meeting & $:$ & $1-2$ \\
\hline Time Allotment & $:$ & $200^{\prime}\left(@ 100^{\prime}\right)$ \\
\hline Theme/ Topic & $:$ & English Independent Study \\
\hline
\end{tabular}

\section{Competence:}

At the end of the meeting, students are expected to understand the concept of English independent study and to be able to implement its practical implications in their daily lives. The ultimate goal of EIS training is to encourage students to do various independent English learning activities in order to complement the classroom learning, and to develop a sustainable independent learning habit to support their lifelong learning of English.

\section{Learning objectives :}

- Students can identify potential English exposure in their immediate environment

- Students can practice various English independent study activities outside the class

\section{Learning materials :}

This particular session discusses the notion of English independent study in terms of the definition, the underlying basis, the principles, the purposes and the practical implications.

\section{Learning methods :}

- Discussion

- Small Group Works 


\section{Procedure :}

\section{Meeting 1 (100')}

\begin{tabular}{|c|c|}
\hline $\begin{array}{l}\text { Pre- } \\
\text { teaching } \\
\text { (10') }\end{array}$ & $\begin{array}{l}\text { 1. Mentor opens the session and greet the students } \\
\text { 2. Mentor checks students attendance and other requirements } \\
\text { 3. Mentor introduces the topic of today's session: English Independent Study } \\
\text { (EIS) }\end{array}$ \\
\hline & $\begin{array}{l}\text { 4. Students are asked if they know anything about what independent study is } \\
\text { 5. Mentor briefly explains about the definition, the goal, the underlying basis, and the } \\
\text { principles of English independent study. } \\
\text { 6. Students are given some examples of some EIS activities that they could integrate } \\
\text { in their daily lives } \\
\text { 7. Students are asked to work in pair or in small groups to brainstorm some potential } \\
\text { EIS activities in their immediate environment asmany as possible } \\
\text { 8. Students are informed that the list of their EIS activities should be used to guide } \\
\text { them to do their EIS activities for the next weeks. Mentor walks around and make } \\
\text { sure each group understands the assigned task, occasionally reminds studets about } \\
\text { the nature and the principles of EIS activities, and offers assistance as necessary. } \\
\text { 9. Each group are asked to share their list of EIS activities to the whole class. The first } \\
\text { group can share their complete list, and the next groups add activitiesthat are not } \\
\text { yet mentioned by the previous group. } \\
\text { 10. Mentor inform students that the goal of this activity is to share and inspire each } \\
\text { other about potential EIS activities that they may be able to do. }\end{array}$ \\
\hline $\begin{array}{l}\text { Post } \\
\text { activi } \\
(10 ')\end{array}$ & $\begin{array}{l}\text { 11. Mentor leads students to review today's session } \\
\text { 12. Students are reminded that they are expected to try some EIS activities that they } \\
\text { have brainstormed today and share about it in the next meeting. } \\
\text { 13. Mentor explains about the EIS weekly report that students should fill in, reminding } \\
\text { them that each week, they are expected to do different EIS activities. } \\
\text { 14. Mentor invites questions or clarification. } \\
\text { 15. Mentor closes the session. }\end{array}$ \\
\hline
\end{tabular}

\section{Meeting 2 (100')}

\begin{tabular}{|c|c|}
\hline $\begin{array}{l}\text { Pre- } \\
\text { teaching } \\
\left(\begin{array}{lll}1 & 0 & 0\end{array}\right)\end{array}$ & $\begin{array}{l}\text { 1. Mentor opens the session and greet the students } \\
\text { 2. Mentor checks students attendance and other requirements } \\
\text { 3. Mentor introduces the topic of today's session: sharing about EIS activities }\end{array}$ \\
\hline $\begin{array}{l}\text { Whilst } \\
\text { Teaching } \\
\text { (80') }\end{array}$ & $\begin{array}{l}\text { 4. Students are asked if they tried some EIS activities they have discussed in the } \\
\text { previous meeting. } \\
\text { 5. Students are asked to submit the written EIS weekly report to the mentor. } \\
\text { 6. Students are asked to work in pairs or small groups and share about the EIS } \\
\text { activities they have tried this week. } \\
\text { 7. Mentor walks around to make sure students understand and do the assigned task. In } \\
\text { the meantime, mentor also check students' written weekly report to ensure that all } \\
\text { students comply with the instruction. } \\
\text { 8. After the group sharing, students are asked to retell their peer's EIS experience to } \\
\text { the whole class. The small group sharing and the whole class retelling is intended to } \\
\text { provide students with more opportunities to talk and practice their English. } \\
\text { 9. As students recount their peer's EIS experience, mentor ensures that each } \\
\text { misunderstanding or lack of understanding about EIS is well addressed. For } \\
\text { example, if a student shares about trying to read a text that he thinks is very } \\
\text { difficult, he and the class should be reminded that one of EIS principles is to find a } \\
\text { material that are not too difficult nor too easy. Thus, for the next EIS activities, } \\
\text { encourage them avoid such difficult text, and find materials with appropriate level } \\
\text { of difficulty. }\end{array}$ \\
\hline $\begin{array}{l}\text { Post } \\
\text { activities } \\
(10 ')\end{array}$ & $\begin{array}{l}\text { 10. Mentor leads students to review today's session. } \\
\text { 11. Mentor invites questions or clarification. } \\
\text { 12. Mentor reminds students that they are still expected to continue the EIS activities } \\
\text { and fill in the written EIS report each week. If time allows, the first 5-10 minutes of } \\
\text { each session will be used for sharing about students EIS activities. } \\
\text { 13. Mentor informs students about next meeting's topic and asks them to prepare by } \\
\text { reading and/ or watching the prepared materials in advance. } \\
\text { 14. Mentor closes the session. }\end{array}$ \\
\hline
\end{tabular}


Media \& resources :

- Handout about English Independent Study

- Worksheet on identifying potential EIS activities
Whiteboard and board marker (if available)

\section{Scoring Rubric :}

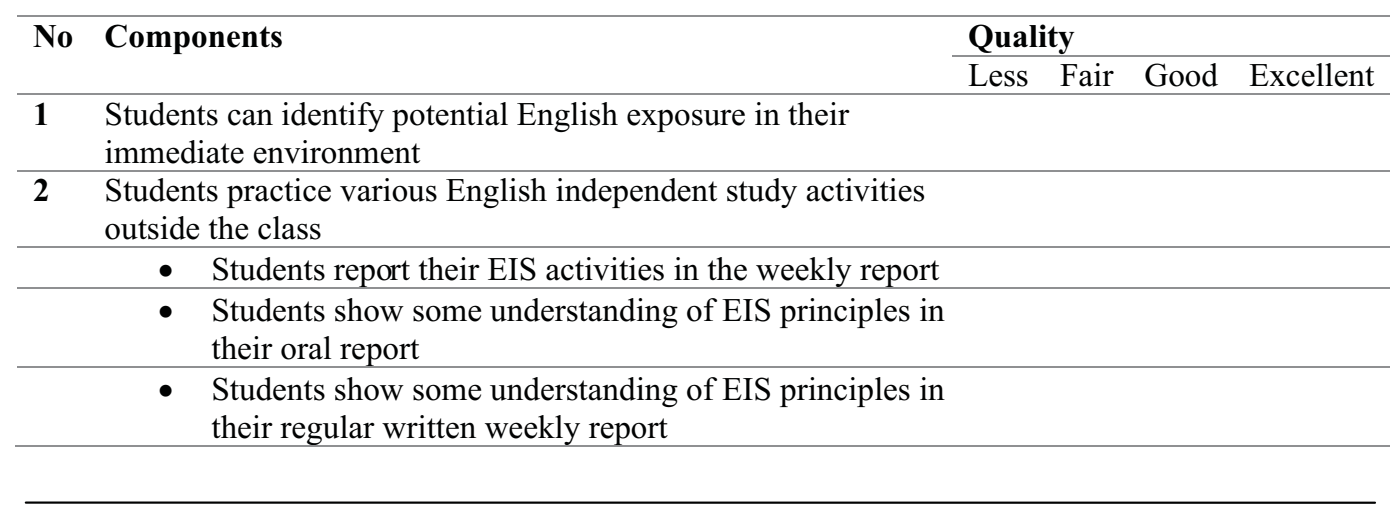

\section{Program Evaluation}

Analysis of the data obtained from the survey administered to both mentors and mentees at the end of the Mentoring program showed that this pilot program possessed some strengths and weaknesses. The survey was an open one, aimed to capture honest impression on the program by the respondents, free from any form of influence. The evaluation survey form consists of five sections; timing, venue, module, mentor/mentees and general impression about mentoring program. In addition, the evaluation form for the mentors includes an additional section of scoring rubrics. Below is the summary of the analysis results.

\begin{tabular}{lcc}
\hline \multicolumn{1}{c}{ Aspect } & Positive Reviews & Negative Reviews \\
\hline Timing & $64 \%$ & $36 \%$ \\
\hline Venue & $53 \%$ & $47 \%$ \\
\hline Module & $72 \%$ & $28 \%$ \\
\hline Mentor & $88 \%$ & $12 \%$ \\
\hline Scoring Rubrics & $95 \%$ & $5 \%$ \\
\hline General Impression & $92 \%$ & $8 \%$ \\
\hline
\end{tabular}

\section{Strengths of the Program}

The results of analysis about the strengths of the 2015 Mentoring Program are presented based on the aspects contained in the survey. In terms of timing, the strengths include that Saturday meeting allowed mentors and mentees to focus on their formal classes on weekdays, and that the starting time was good - not too early nor too late in the morning, a time when everyone was still fresh. In addition, the duration of each mentoring session (100 minutes) was considered sufficient and effective. Next, outdoor venue was another strengths of the program, as it was reported to be comfortable and conducive for learning. Furthermore, in terms of the module, its strengths were that it was helpful, informative, easy to understand, and with good and easy topics for speaking. In terms of the mentors, the strengths mentioned were that they showed good attitude, kind, friendly, helpful, patient, fun, motivating, clear in explaining, always spoke English, and liked to share additional information in addition to the topic of the lesson. In general, the mentors and mentees reported that the program 
should be continued as it was helpful both to increase their English skills as well as in teaching, and that there was character building for both mentors and mentees in the program.

\section{Weaknesses of the Program}

In addition to the strengths, the survey results analysis also revealed the weaknesses of the program. In terms of the timing, the weaknesses mentioned was that Saturday meeting took away their weekend and that 8 am starting time was considered too early. Then, outdoor venues, despite providing new learning atmosphere, were sometimes less conducive for learning and lacking in learning media. As for the module, the weaknesses found was that it was boring as it was not colorful, less understandable, and contained too many assignments. Finally, the weaknesses in terms of the mentors were that some of them were boring, not punctual, less prepared, lack of control, and too domineering in talking.

With regards to the weaknesses, some suggestions were also offered by the mentors and mentees. First, in terms of the timing, some suggestions found were that the mentoring time should be made flexible in accordance with the group's free time, that the program should be one year long and that there should be more time for storytelling activity. Second, some suggestions made about the venue for the next mentoring program includes that the venue should be booked in advanced so as to avoid being used by other people, and that it could be made flexible, such as by alternating between one venue to another. As for the module, future mentoring module were expected to contain materials with lower level of difficulty as some materials were considered too difficult by the mentees. In addition, the module could contain more lessons, pictures and games or music for listening, and it could be printed in color. Finally, some suggestions made for mentors are that they should be well trained, they should talk less, and that they should be more well prepared, for example with some additional materials.

\section{DISCUSSION}

Mentoring program is designed to assist the first year students to be able to practice speaking English confidently. Some considerations serving as the background of this program was because of the students' relatively high proficiency gap, most probably due to different previous English training in their secondary schools. As a results, some students were more confident to speak English while many others were less confident. Therefore, the objective to conduct the Mentoring Program for the first year students was to bridge students' different proficiency gap in order that their English skills could be relatively equal among each other.

This proficiency gap due to different previous training is theoretically understandable since speaking in foreign language is a complex skill. Harris (1994, in Somjai and Jansem, 2015) states that speaking requires simultaneous use of several abilities which generally develop it different speed. He adds that there are five components of speaking; pronunciation, grammar, vocabulary, fluency, and comprehension. Harmer (2002) suggests that the basic components of speech area to be mastered are grammatical competence, sociolinguistic competence, discourse competence, and strategic competence. $\mathrm{Ni}$ (2012) also adds that the lack of 
self-confidence among students may causes fearful and timid attitude, shyness in expressing opinions and inability to make meaningful sentences when speaking in class activities. With such complexity, graded assistance for students to practice speaking confidently is believed to be helpful for learners.

The assistance offered in the mentoring program organized by the English Department of UMM is in line with the spirit of mentoring in general, which is defined as the activity of providing assistance in learning English to junior students by the more senior and experienced students. In this program, students work in team of 10-12 with the mentors playing the role as facilitator and supervisor in learning English Language. As suggested by Dornyei (2001), collaborative learning is believed to create positive learning atmosphere and to develop learners' self-esteem and confidence. This is corroborated by the findings of questionnaire and observation which shows that the students or mentees learned more eagerly with this model of learning. The small number of students could create a more conducive learning atmosphere for practice speaking in English with higher level of freedom and safety. Furthermore, assistance from the mentors - who are senior students (and not teachers/ lecturers) - and outdoor learning venues, are found to help them better to start talking due to the informal learning situation resulted. It was especially a good start for those who felt intimidated by the formality of regular classes and are too shy to talk there.

Based on the findings on this study, it was found that generally, the 2015 Mentoring program was well implemented. The elements of the program, such as module, lesson plans, scoring rubrics were reviewed mostly positively by the mentors and mentees. The mentoring agenda was also run as planned, with the timing and venue gaining the most polarized review, showing that althought many students agree with the timing (Saturday morning) and venue (outdoor gazebos) for the program, many other students were concerned and expect change and improvement.

In addition, the three mentoring goals-English Independent Study, presentation, and debate-were selected attentively so as to help strengthening students' English Language foundation. First, the English Independent Study (EIS) was targeted to help the mentees to develop good learning habit on their own accord, without having to depend on the presence of teachers or classes. As suggested by Smith (2008) and Inayati (2015), higher autonomy in foreign language learning and rich exposure to the language is believed to contribute to the success of learning. In addition, Yanren (2007) also confirm such believe in her study on successful Chinese learners of English Language who reported studying independently as one of the biggest factor influencing their success. In other words, it could be said that EIS is the starting point for students to mind map and start their own learning of English at their own pace and without any pressure by being continually exposed to the language and acquire the language components there, especially the vocabulary.

The second focus of the program, presentation skill, was expected to be the place for students to train their public speaking skills. The main goal of the training is for students to be able to talk systematically and understandably in English by making use of verbal and 
non-verbal expressions. As suggested by Nadia (2013) oral presentation could serve as an effective way to develop student's ability to practice speaking as well as to improve their performing skill before a number of audience. This is supported by a study conducted by King (2002, in Nadia 2013) who found that oral presentation training could improve student's English Language proficiency level. The training of presentation skills in English given in the first year of study is expected to serve as the basic skill which will be continually sharpened as they practice presenting during classes throughout their study years. Eventually, it is projected that by the end of their four year study in the university, they would be competent speakers of English who could present in front of audience fluently and confidently.

The last focus of the program, debating skills, is a place for students to train their skills in making and defending arguments. Debate is a skill to deliver convincing arguments in order to provoke a particular party to believe certain standpoint over an issue. The debating skill training focuses on assisting students to practice critical thinking, structuring ideas and delivering the ideas using convincing arguments. In this Mentoring Program, students are not directly asked to confront an idea, but they are trained to think argumentatively with 'why' concept. Many students tend to accept any kind of information without criticizing the information by asking 'why' they should believe it, 'why' it is like that and other 'why'. Once they know how to criticize a particular statement and to design their argumentative reasoning, then students come to practice to defend their belief by dividing them into pros (affirmative) and cons (negative) teams. This debate technique is also believed to improve students' speaking ability as found in Somjai and Jansem's (2015) study based in Thailand. By employing mixed method approach using students' pre-test/post-test and questionnaire perception toward the implementation of debate in class, it was found that students' ability in speaking was significantly improved and that students reported that training on debate not only improved their cognitive but also their affective skills.

Indeed, informal observation conducted during the classes taught by some lecturers reported that during the Mentoring Program, students learning performance were relatively more positive. Some students who usually participated less in class discussion looked more confident in delivering their ideas; some may have felt that their English was getting better so that they tried to speak English and contribute to the discussion at any moment.

\section{CONCLUSION}

The 2015 Mentoring Program organized by the English Department of UMM was relatively well executed. Focusing on three aspects English independent study, presentation and debate, the program aims to help strengthening the first year students' English Language foundation by encouraging and teaching them various strategies to learn the language autonomously and by giving them basic training in public speaking, critical thinking and developing convincing arguments through presentation and debate training. The program was meant to be semi-formal and student-centred which was approached by the employment of senior 
students as mentors and the use of outdoor venues. To ensure that the three mentoring foci were achieved, mentoring handbook, lesson plans and scoring rubrics were made available for mentors, while the mentees were provided with the handbook only.

Evaluation of the program given by the mentors and mentees shows that in general, the program was viewed positively and is expected to be continued in the future. Some aspects gaining mostly positive reviews include the handbook, the mentors, and the scoring rubrics. However, the timing and the venues provided for the program gained a more polarized review in which the positive and negative reviews were almost equally distributed. Nevertheless, almost all students suggested that the program should be continued since they felt that it benefited them in many ways, especially in terms of improving their English Language in general and specifically speaking skills.

Based on the study, some suggestions are offered for the next mentoring program, for the department and for the future researchers. First, the next mentoring program is expected to address all the negative reviews and improve upon them, for example by changing the time to suit everybody's interests, improving the venues by pre-booking the outdoor venues for the program and making sure that all mentoring groups meet outdoor, ensuring high quality mentors, and improving the involvement of all supervisors. For the department, it is expected to provide more support for the program such as by providing more human resources for mentoring team, and by providing more guidance and facilities for the program.
Finally, this study about the 2015 Mentoring program still has some limitations that future researchers could improve upon. For example, researchers who wish to study about the program in the future could focus more on the outcome of the program for example by rigorously measuring the change in students' English Language proficiency, especially in speaking skills, or the change in their confidence when speaking English or in their learning motivation. In addition, they could also focus on the mentees' and mentors' learning experience during the program. Finally, the supervisors' inputs for the program could also be elaborated and analyzed since they were the ones who were in direct touch with the mentors during the execution of the program.

The 2015 Mentoring program is a pilot project which is expected to be the starting point of the next mentoring programs in the future. By providing systematic review for the project, this study could serve as a basis to improve the same program in the future in English Department of UMM, and this could also be used as inspiration or reference for other institutions who wish to implement similar project.

\section{REFERENCES}

Arnold, E. (2006). Assessing the quality of mentoring: sinking or learning to swim?. ELT Journal, 60(2), 117-124.

Balassa, K., Bodo' czky, C., \& Saunders, D. (2003). An impact study of the national Hungarian mentoring project in English language training. Mentoring \& Tutoring, 11(3), 307-320.

Crabbe, D. (1993). Fostering autonomy from within the classroom: The teacher's responsibility. System, 21(4), 443-452. <http://dx.doi.org/10.1016/ 0346-251X(93) 90056-M> 
Cambridge Dictionaries Online. (2015). "Mentor", Retrieved from http:// www.oxforddictionaries.com / definition/english/mentor.

Chaney, A. L., \& Burk, T. L. (1998). Teaching Oral Communication in Grades $K-8$. Iowa: Allyn and Bacon.

Cooper, D. (2005). Assessing what we taught: The Challenges faced with the assessment of oral presentation skill. Higher Education in a Changing World, 124-132.

Harmer, J. (2002). The practice of English language teaching $\left(3^{\text {rd }} \mathrm{Ed}\right)$. Longman: New York.

Inayati, N. (2015). Promoting English Independent Study for EFL University Students in Indonesia. Language Education in Asia (LEiA), 6(1), 46-57. http://dx.doi.org/10.5746/ LEiA/15/V6/I1/A5/Inayati

Krashen, S. (1982). Principles and practices in second language acquisition. Oxford, UK: Pergamon. Available from: <http://www. sdkrashen.com/content/ books/ principles_and_practice.pdf $>$

Kullman, J. (1998). Mentoring and the development of reflective practice: Concepts and context. System, 26(4), 471-484.

Smith, R. (2008). Learner autonomy. English Language Teaching Journal, 62(4), 395-397. http:// dx.doi.org/10.1093/elt/ccn038

Nadia, Z. (2013). The Use of Students' Oral Presentations in Enhancing Speaking Skill in the English Language Classrooms: the case study of second year students at the Department of English in Biskra University. Master Program Dissertation, Biskra University, Algeria.
Ni, H. (2012). The effects of affective factors in SLA and pedagogical implications. Theory and Practice in Language Studies, 2(7), 1508-1513.

Quinn, S. (2005). Debating. Retrieved from http://www.learndebating.com/ DEBATING.pdf.

Somjai, S \& Jansem, A. (2015). The use of debate technique to develop speaking ability of grade ten students at Bodindecha (Sing Singhaseni) school. International Journal of Technical Research and Applications. Special Issue 13, 2731

Wong, L. C., \& Nunan, D. (2011). The learning styles and strategies of effective language learners. System, 39, 144-163. http://dx.doi.org/ 10.1016/j.system.2011.05.004

Yahay, M., \& Kheirzadeh, S. (2015). The Impact of Oral Presentation on Fluency and Accuracy of Iranian EFL Learners' Speaking. Journal of Applied Linguistics and Language Research, 2(5), 114-123.

Yanren, D. (2007). Text memorization and imitation: The practices of successful Chinese learners of English. System, 35(2), 271-280. <http://dx.doi.org/ 10.1016/ j.system.2006.12.005>

Yu, S.-H., \& Cadman, K. (2009). EFL Leaners' Connection with Audience in Oral Presentations: The Significance of Frame and Person Markers. TESOL in Context, s2. 


\title{
PRAKTIK KOLABORATIF PEMBELAJARAN BIOLOGI MATERI REPRODUKSI BERBASIS LESSON STUDY DI SMA NEGERI 1 SUMBERPUCUNG
}

\author{
Purwatiningsih, Roro Eko Susetyarini, Ainur Rofieq, dan Roimil Latifa \\ SMA I Negeri Sumberpucung \\ Email: niniek08@gmail.com
}

\begin{abstract}
ABSTRAK
Pembelajaran praktik kolaboratif berbasis Lesson Study di SMA untuk meningkatkan kualitas pembelajaran yang memperhatikan hak belajar setiap peserta didik. Tujuan penelitian untuk mendekrispsikan kegiatan Lesson Study dengan praktik kolaboratif di SMAN I Sumberpucung kabupaten Malang. Penelitian ini untuk memecahkan masalah yang berkaitan dengan pembelajaran yang berbasis Lesson Study produk biologi berupa media pembelajaran dengan praktik kolaboratif. Metode penelitian yang digunakan deskriptif. Responden yang digunakan guru dan siswa SMAN I Sumberpucung. Langkah yang dilakukan, yaitu: workshop LS, perencanaan perangkat pembelajaran berbasis LS dilakukan 4 siklus, pelaksanaan pembelajaran berbasis LS dilakukan 4 siklus, refleksi pelaksanaan pembelajaran berbasis LS dilakukan 4 siklus, respon siswa tentang kolaboratif, komunikatif, kreatif dan berpikir kritis setelah pembelajaran berbasis LS dengan praktik kolaboratif. Hasil dari praktik kolaboratif berbasis Lesson Study materi Reproduksi di SMAN I Sumberpucung 100\% terbentuk Chapter Design I, II, III,dan IV; Lesson Design I, II, III dan IV, Ada perbedaan Lesson Design antara siklus I dengan siklus II, III dan IV. Pada siklus I metode yang digunakan Problem Base Learning, siklus II, III, dan IV menggunakan metode project Base Learning. Pada pelaksanaan pembelajaran siswa berkolaborasi, berkreasi, berkomunikasi dan berpikir kritis dalam pembuatan media. Data respon siswa praktik kolaboratif tentang materi reproduksi 99\% siswa sangat suka dengan pembelajaran berbasis LS.
\end{abstract}

Kata Kunci: Kolaboratif, Reproduksi, Lesson study, Project Base learning,

\begin{abstract}
Lesson study collaborative lessons is applied in high school to improve the quality of learning that takes into account about the rights of learning of each learner. The purpose of this research is to decrypt the lesson study activities with collaborative practices in SMAN I Sumberpucung Malang. This research is solving the problems related to learning based on Lesson study of Biology products are in the form of learning media with collaborative practice. This research employs descriptive method. The respondents of the research are teachers and students of SMAN I Sumberpucung. The steps taken were: LS workshop, LS based learning tool planning 4 cycles, LS-based learning implementation 4 cycles, reflection of LS based learning implementation 4 cycles, student responses on collaborative, communicative, creative and critical thinking after LS based learning with collaborative practice. The results of collaborative practice based on Lesson study of Reproduction teaching materials at SMAN I Sumberpucung formed Chapter design I, II, III, and IV; Lesson design I, II, III and IV, There is a difference of lesson design between cycle I with cycle II, III and IV. In the first cycle, the method used problem base learning while cycle II, III, and IV are using the method of project base learning. In the implementation of the research, the students are learning to collaborate, be creative, communicate and think critically in making media. Student response of data collaborative practice on reproduction teaching materials showed that $99 \%$ of students are particularly fond of LS based learning.
\end{abstract}

Key word: Colaboratif, Reproduction, Lesson Study, Project Base Learning 


\section{PENDAHULUAN}

Permasalahan yang sering dialami adalah peningkatan kemampuan guru dalam mengajar merupakan satu kesatuan dalam praktek kegiatan pembelajaran. Pelaksanaan pembelajaran merupakan kegiatan yang kompleks dan rumit. Untuk melakukan kegiatan tersebut guru harus menentukan materi dan menyusun rancangan pelaksanan pembelajaran serta memikirkan jalan pemikiran dan reaksi siswa dalam kegiatan yang akan didating, bila guru tidak menguasai materi maka RPP yang bermutu dan berinovasi tidak dapat disusun (Masaaki, 2014).

Pembelajaran merupakan proses interaksi antara pengajar, siswa, dan media pembelajaran, dengan adanya interaksi tersebut, siswa dapat secara aktif mengembangkan keterampilan dan pola pikir dalam belajar. Pembelajaran berlangsung secara interaktif, inspiratif, menyenangkan, menantang, serta dapat memotivasi siswa dalam mencapai kompetensi yang diharapkan (Rustaman, 2003).

Pembelajaran yang menyenangkan, inovatif dan menantang merupakan pembelajaran yang mengarah ke sekolah model abad 21. Sekolah modern dibentuk berdasarkan prinsip daar pencapaian simultan antara kualitas (quality) dan kesetaraan (equality) (Sato, 2014).

Dalam menyongsong abad 21 perlu adanya refromasi di dalam sekolah dan proses pembelajaran. Reformasi sekolah mempunyai visi dan filosofi, yaitu komunitas belajar (Learning community). Misi dari komunitas belajar di sekolah adalah menjamin hak belajar setiap anak dan meningkatkan kualitas pembelajaran (Sato, 2014). Hal ini merupakan tantangan bagi sekolah karena harus ada kesepakatan antar kepala sekolah, guru, komite sekolah maupun dinas pendidikan.
Komunitas belajar menurut filosofinya ada 3 kegiatan, yaitu pembelajaran kolaboratif di dalam kelas, pembentukan komunitas belajar professional dan kolegialitas para guru, serta partisipasi orang tua dan masyarakat.

Hasil observasi awal, pada umumnya guru cenderung di dalam proses kegiatan pembelajaarn di kelas selalu menggunakan metode diskusi karena di dalam metode diskusi belum terjadi saling belajar antar anggota kelompok dan didominasi oleh satu oarng yang aktif. Oleh karena itu perlu dikembangkan pembelajaran kolaboratif di dalam proses kegiatan pembelajaran. Pembelajaran kolaboaratif terdiri dari 3 hal, yaitu 1). Pembelajaran otentik (pembelajaran yng sejalan dengan karateristik mata pelajaran), 2). Hubungan saling belajar (hubungan saling mendengarkan), 3). Pembelajaran yang terdapat lompatan/jumping (pembelajaran yang bersifat kreatif dan menantang) (Sato, 2014).

Setiap guru pada satuan pendidikan berkewajiban mengembangkan pembelajaran berlangsung secara interaktif, inspiratif, menyenangkan, menantang, memotivasi peserta didik untuk berpartisipasiaktif, serta memberikan ruang yang cukup bagi prakarsa, kreativitas, dan kemandirian sesuai dengan bakat, minat, dan perkembangan fisik serta psikologis peserta didik. Seorang guru pada satuan pendidikan jenjang Sekolah Menengah Atas (SMA), baik dalam tuntutan kompetensi pedagogik maupun kompetensi profesional, berkaitan erat dengan kemampuan guru dalam mengembangkan pembelajaran yang sesuai dengan karakteristik peserta didik.

Lesson Study (LS) adalah model pembinaan (pelatihan) profesi pendidik melalui pengkajian pembelajaran secara 
kolaboratif dan berkelanjutan berlandaskan prinsip-prinsip kolegialitas yang saling membantu dan mutual learning untuk membangun komunitas belajar. Lesson Study merupakan komunitas belajar (learning society) yang secara konsisten dan sistematis melakukan perbaikan diri, pada tataran individual maupun manajerial. Pembelajaran secara kolaboratif dan berkesinambungan merencanakan, melaksanakan, mengobservasi dan melaporkan hasil pembelajaran (Supriatna, 2012).

Pelaksanaan LS meliputi beberapa tahap, yaitu perencanaan (plan), pelaksanaan (do) dan refleksi (see), kegiatan ini dilakukan oleh sekelompok guru. LS dapatdibelajarkan pada guru, karena LS dilakukan secara berkala dan berkelanjutan dalam rangka meningkatkan kompetensi dan keprofesionalan guru. Kegiatan LS dalam pembelajaran, selain sebagai upaya mengaktifkan siswa berdampak pada guru dapat melakukan review terhadap kinerja guru dan pengembangan kemampuan akademik dan berpikir kritissiswa serta menumbuhkan sikap berhati-hati dan bertanggung jawab dalam belajar. LS akan diobservasi dan direfleksi bersama-sama oleh observer dan guru model. Guru-guru yang ber Lesson Study masih sekitar 25\%, metode pembelajaran yang sering digunakan diskusi, diskusi belum sepenuhnya mengarahkan pembelajaran kolaboratif, maka perlu adanya implementasi Lesson Study for Learning Community di SMA tersebut untuk meningkatkan kualitas pembelajaran dan pembelajaran yang memperhatikan hak belajar setiap peserta didik sama pada matapelajaran Biologi materi reproduksi. Tujuan penelitian untuk mendekrispsikan kegiatan praktik kolaboratif pada pembelajaran Biologi materi Reproduksi berbasis Lesson Study SMA Negeri 1 Sumberpucung.

\section{METODE}

Jenis penelitian yang digunakan adalah penelitian deskriptif. Responden yang digunakan adalah guru-guru SMA Negeri 1 Sumberpucung dan siswa kelas XII Sumberpucung Kabupaten Malang. Langkah-langkah yang dilakukan: 1) Workshop dan Sosialisasi Lesson StudyLearning Community, kegiatan workshop ini diawali dengan sosialisasi kepada para guru dan dilaksanakan 1 kali di awal kegiatan. 2) Pembuatan perencanaan perangkat pembelajaran Praktik Kolaboratif. Pembelajaran berbasis LS dengan praktik pembelajaran kolaboratif, diterapkan dengan kegiatan menyusun perangkat pembelajaran olehguru model terpilih berupa RPP dan silabus pembelajaran berbasis LS, berupa 1 Chapter Design dan 4 Lesson Design untuk 4 siklus LS. Focus pembelajaran untuk peserta didik, yaitu pembelajaran berbasis praktik. 3) Penerapan Pembelajaran Biologi Berbasis LS dengan pembelajaran kolaboratif di kelas. RPP (Lesson Design) dan materi (Chapter Design) pembelajaran telah tersusun, guru model melakukan pembelajaran di kelas dan didampingi beberapa observer (dari guru SMA Negeri 1 Sumberpucung dan Dosen Biologi FKIP UMM). Pelaksanan pembelajaran berfokus pada kemampuan berpikir kritis dengan bahasan praktik biologi dengan pratik pembelajaran kolaboratif dilakukan 4 kali pertemuan (4 siklus), jadwal pelaksanaan disesuaikan dengan jadwal guru-guru di sekolah. 4) Penerapan Refleksi Pembelajaran Praktik Biologi Berbasis LS-LC di kelas.

Guru model, setelah melakukan pembelajaran di kelas dengan beberapa 
observer (dari guru SMAN I Sumberpucung di kabupaten dan Dosen Biologi FKIP UMM) melakukan refleksi. Saat refleksi didiskusikan apa yang bisa diungkap cara belajar siswa dari para observer. Refleksi dilakukan sesuai siklus yang digunakan.

\section{HASIL DAN PEMBAHASAN}

Hasil pelaksanan praktik kolaboratif pembelajaran Biologi materi Reproduksi berbasis LS SMAN I Sumberpucung sebagai berikut.

\section{Sosialisasi dan Workshop LS-LC tanggal 27 Pebruari 2017}

Workshop LS-LC dilaksanakan pada tanggal 27 Pebruari 2017 di ruang rapat SMAN I Sumberpucung yang dihadiri oleh 17 guru dan dosen UMM. Sosialisasi tentang reformasi sekolah menghadapi sekolah abad 21. Peserta didik diharapkan mempunyai kompetensi $4 \mathrm{C}$ : kolaboratif, kreatif, komunikasi, dan berpikir kritis. Saat pelaksanaan workshop LS di SMAN I Sumberpucung, disajikan pada Gambar 1.

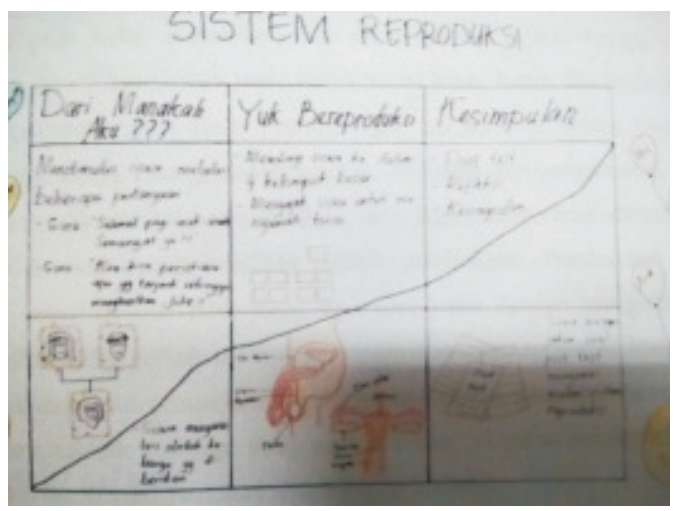

Gambar 1. Saat Workshop LS

Pada saat workshop dihasilkan Chapter Design, Lesson Design tentang sistem reproduksi dan kesepakatan guru model untuk open class, disajikan pada Gambar 2, 3 dan 4.

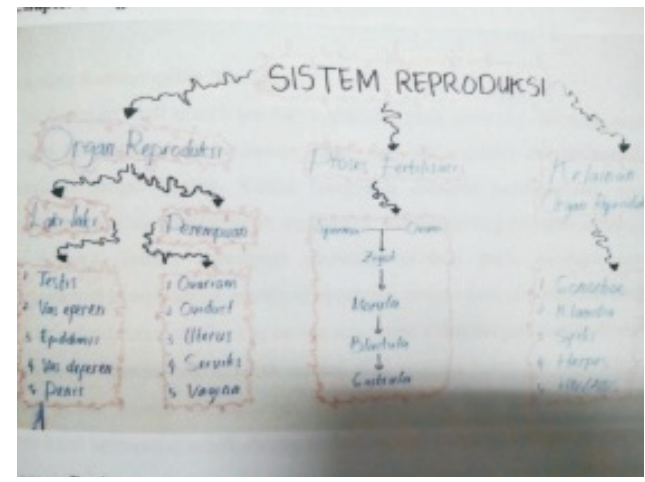

Gambar 2. Chapter Design

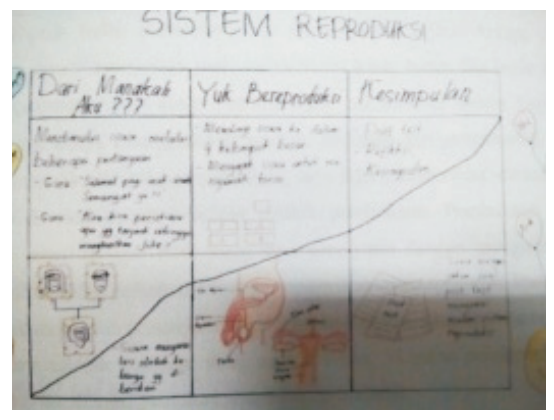

Gambar 3. Lesson Design

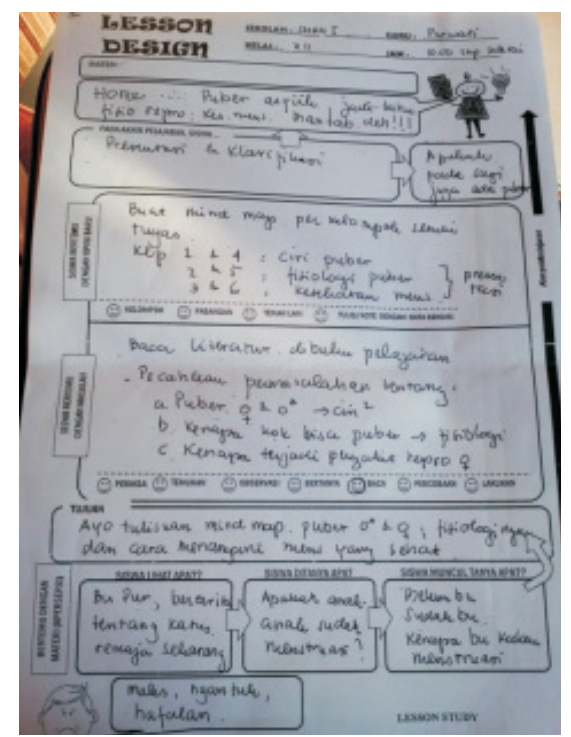

Gambar 4. RPP I

Chapter Design yang dibahas adalah materi reproduksi untuk kelas XII. Reproduksi yang dibahas adalah organ reproduksi pria dan wanita; proses fisiologi reproduksi dan kesehatan reproduksi. Lesson Design yang dibuat menggunakan metode PBL. Siswa diberi permasalahan tentang reproduksi, yaitu: 
1. Bagaimanakah fisiologi organ reproduksi pada masa pubertas lakilaki dan perempuan?

2. Bagaimanakah ciri fisik masa pubertas pada laki-laki dan perempuan?

3. Bagaimana penanganan menstruasi secara sehat?

Siswa mengkaji permasalahan tersebut dengan menggunakan literatur dan mendiskusikan dengan kelompoknya di dalam kelas.

\section{Pelaksanaan Pembelajaran I (open class I) dan Refleksi I.}

Pelaksanaan pembelajaran I atau open class I dilaksanakan pada tanggal 15 Mei 2017 di kelas XII MIA 1 di SMAN 1 Sumberpucung. Jumlah guru dan dosen yang hadir ada 11 orang dan 32 siswa. Di awal pembelajaran guru model bercerita tentang kasus-kasus reproduksi pria dan wanita, kemudian guru model memberikan 3 permasalahan tentang reproduksi. Permasalahan yang diberikan untuk kelompok 1 dan 4 tentang ciri-ciri pubertas pria dan wanita; kelompok 2 dan 5 tentang fisiologi reproduksi, kelompok 3 dan 6 tentang kesehatan menstruasi (Gambar 5 dan 6).

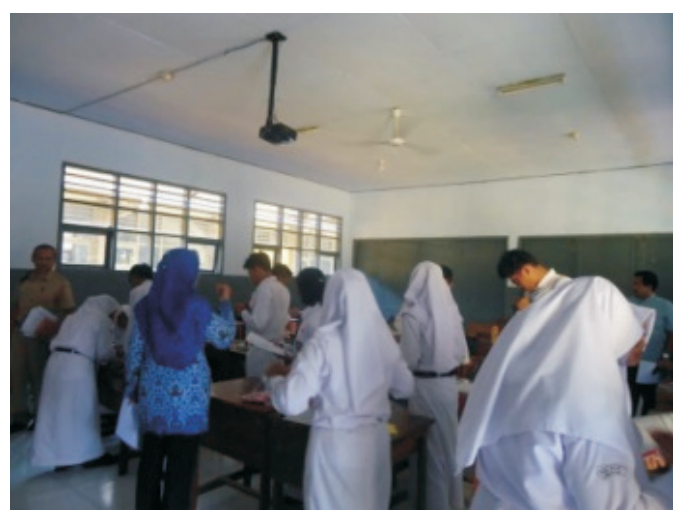

Gambar 5. Saat Guru model apersepsi

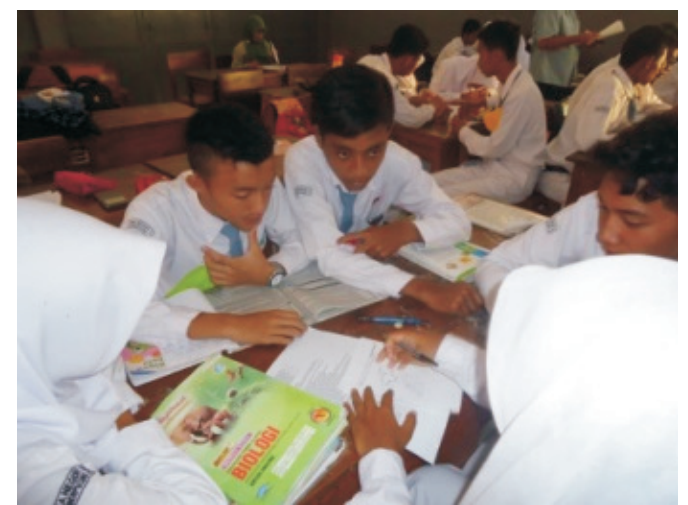

\section{Gambar 6. Kegiatan siswa saat diskusi}

Pada pelaksanaan pembelajaran atau Open Class I pada tanggal $15 \mathrm{Mei}$ 2017 pukul 10.00-11.00 wib, guru model mengkondisikan siswa pada kegiatan awal (Gambar 5) dan kegiatan inti dapat dilihat pada Gambar 6, terlihat siswa berantusias untuk mendiskusikan permasalahan yang telah ditentukan oleh guru model. Siswa berusaha membaca literatur yang dibawa. Siswa belajar untuk berkomunikasi antar teman, berkolaborasi, berpikir kritis dan berinovasi bagaimana menuangkan pemecahan permasalah dalam satu tulisan di kertas manila. Siswa berinteraksi dengan media yang dibawa.

Refleksi pelaksanaan open class I (Gambar 7), Guru model belajar dari siswa yang tadinya malas, ngantuk di kelas ternyata dengan metode $\mathrm{PBL}$, siswa tersebut semangat dan dapat menjelaskan pekerjaan kelompoknya ke kelompok lain. Belajar dari siswa yang bernama si A, ternyata bertanya ke temannya yang cewek tentang bagaimana penanganan menstruasi yang sehat. Belajar dari kelompok 1, kelompok ini juga berliterasi dengan membaca buku, bekerja sama.

Saat pelaksanaan refleksi dilanjutkan dengan open plan untuk open class II 


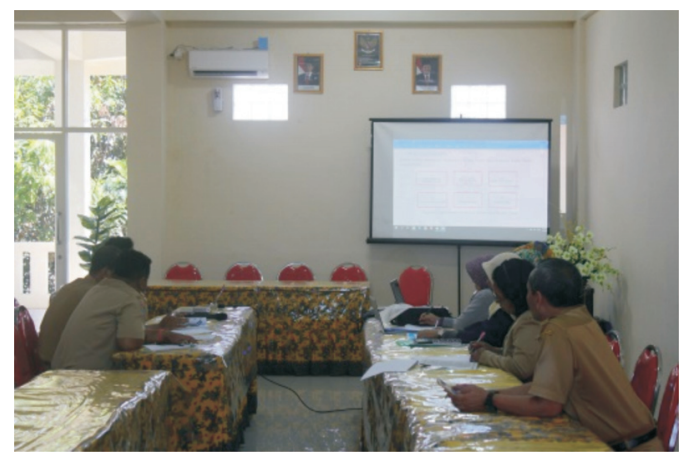

\section{Gambar 7. Refleksi open class I dan open plan II}

Hasil refleksi dari siswa, sebagai berikut. Siswa pertama-tama mencari materi terlebih dahulu, kemudian mengolahnya kedalam mind map. Untuk mengetahui fisiologi organ reproduksi laki laki dan perempuan secara detail, selain itu juga mendapat informasi dari kelompok lain dan merasa sangat senang karena mendapat banyak pengetahuan.

Pada proses pembuatan tugas, sekelompok mengalami barbagai masalah seperti sempat kehilangan file dan foto namun dari berbagai masalah tersebut mendapat banyak pelajaran dengan tidak boleh gegabah, dengan mempersiapkan segala sesuatu dengan matang diawal dan berusaha menampilkan yang lebih baik lagi. Manfaat pembuatan tugas ini lebih memudahkan untuk belajar, menambah pengetahuan yang belum diketahui sebelumnya dan menambah banyak referensi materi ketika membaca. Hasil presentasi menambah wawasan hal-hal mengenai reproduksi, seperti : fisiologi, ciri fisik pubertas, dan penanganan menstruasi secara sehat lebih mendetail. Lebih paham lagi, lebih mampu menjaga diri bagaimana menangani menstruasi yang sehat bagi perempuan. Banyak pelajaran yang didapatkan hari ini, terima kasih.

\section{Perencanaan pembelajaran II (open plan II).}

Pada pelaksanaan perencanaan atau Open Plan II pada tanggal 31 Juli 2017 pukul 10.00-selesai wib. Guru model mempresentasikan RPP (Gambar 8), kemudian didiskusikan dengan tim FKIP UMM dan bapak ibu guru 11 orang. Bapak/ibu guru dan dosen membuat Chapter Design dan Lesson Design (Gambar 9 dan 10).

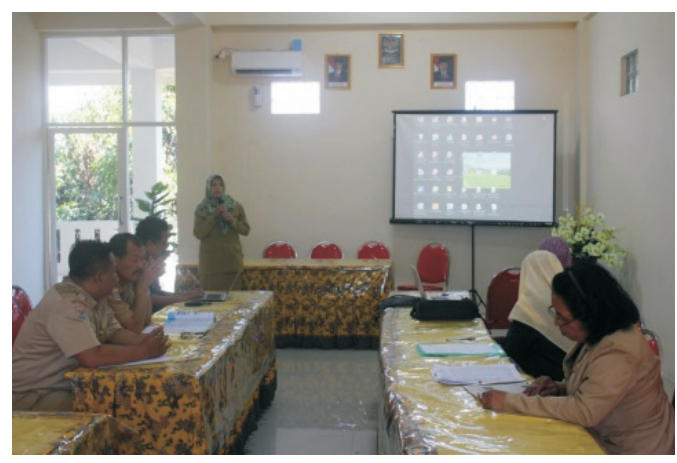

Gambar 8. Guru model presentasi RPP

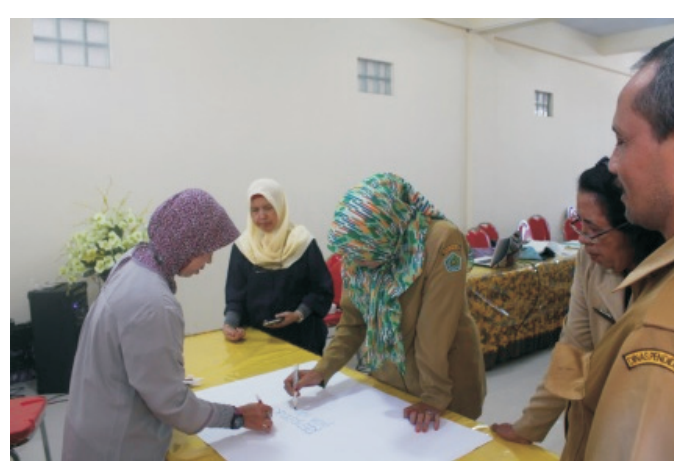

Gambar 9. Saat pembuatan Chapter Design

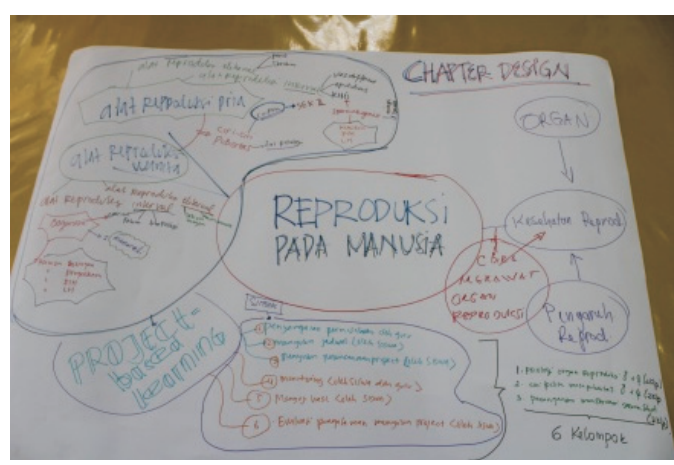

Gambar 10. Chapter Design 


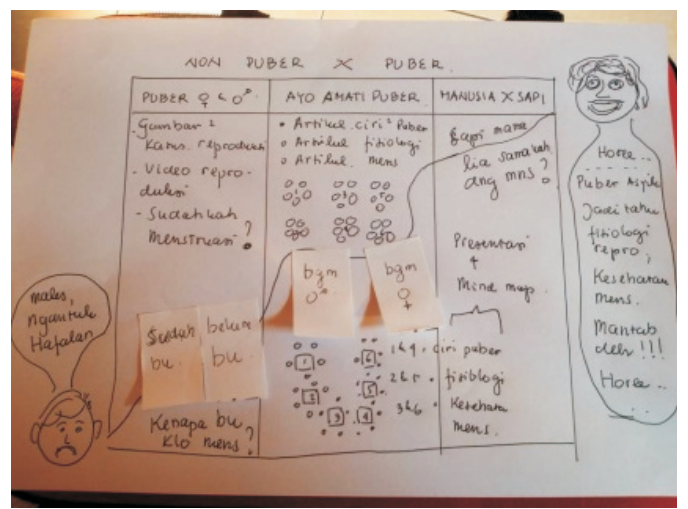

Gambar 11. Lesson Design

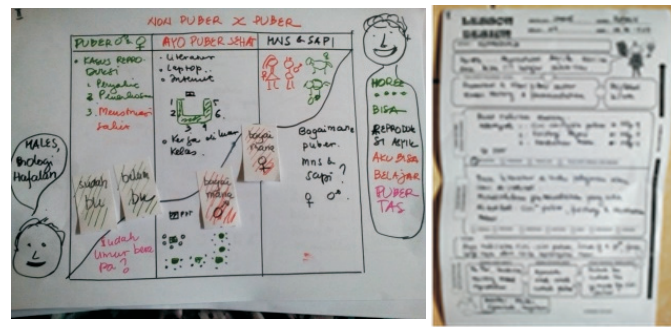

\section{Gambar 12. Lesson Design II dan RPP II}

Hasil diskusi yang berupa Lesson Design dan RPP yang akan digunakan pada saat open class II (Gambar 11 dan 12). Ada perubahan saat pelaksanaan pembelajaran I dengan pelaksanaan pembelajaran II, yaitu metode yang digunakan. Metode untuk pembelajaran I menggunakan PBL tetapi untuk pembelajaran II menggunakan Project Base Learning.
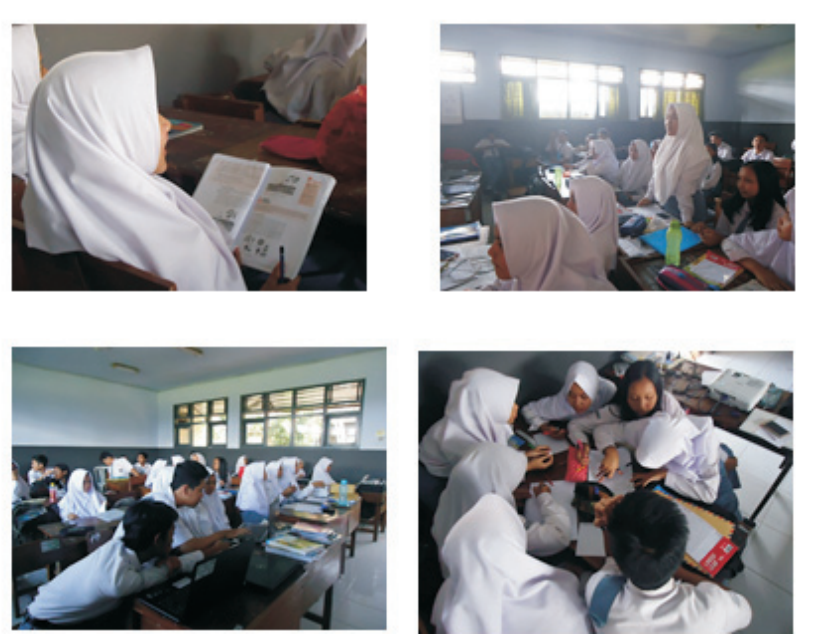

Gambar 14. Suasana siswa saat diskusi

\section{Pelaksanan Pembelajaran II (open class II) dan Refleksi II}

Pada pelaksanaan pembelajaran atau Open Class II pada tanggal 9 Agustus 2017 pukul 10.00 sampai selesai wib, guru model mengkondisikan siswa pada kegiatan awal dan kegiatan inti dpt dilihat pada Gambar 13 dan 14. Gambar 13 dan 14, terlihat siswa berantusias untuk mendiskusikan permasalahan yang telah ditentukan oleh guru model. Di luar kelas siswa berdiskusi memecahkan permaalahan antar teman. Siswa belajar untuk berkomunikasi antar teman, berkolaborasi, berpikir kritis dan berinovasi bagaimana menuangkan pemecahan permasalah dalam satu tulisan di power point. Siswa berinteraksi dengan media yang dibawa.

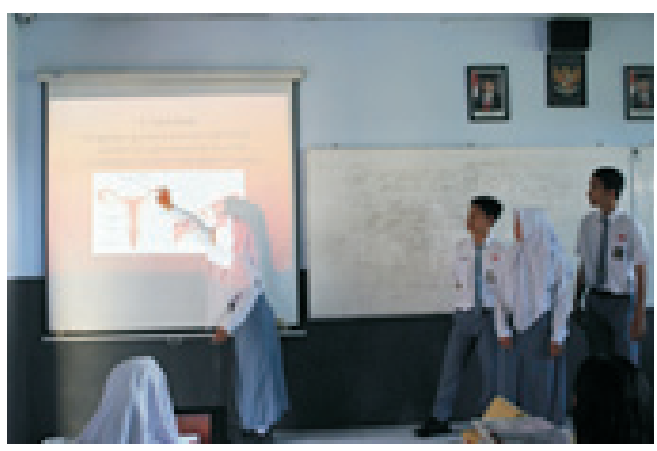

Gambar 13. Siswa Presentasi

\section{i}

Purwatiningsih dkk., Praktik Kolaboratif Pembelajaran Biologi Materi Reproduksi Berbasis Lesson Study di SMA Negeri 1 Sumberpucung 


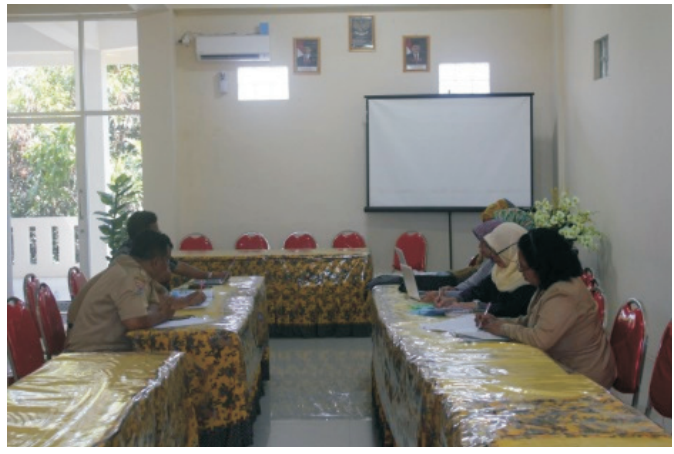

Gambar 15. Refleksi II

Refleksi saat pembelajaran II/open class II. Guru model mengungkapkan bahwa guru model belajar dari siswa muncul kreativitas, keberanian argumentasi (kemampuan berkomunikasi dan arguentasi), saat berdiskusi terjadi kolaborasi. Ada siswa si A pada kelompok 6 yang kurang fokus dengan power point, maka perlu meredesain Lesson Design/RPP. Hasil Lesson Design dan RPP (Gambar 16) yang telah diredesain dengan metode project base learning dengan produk berupa media dimensi 2 atau 3.

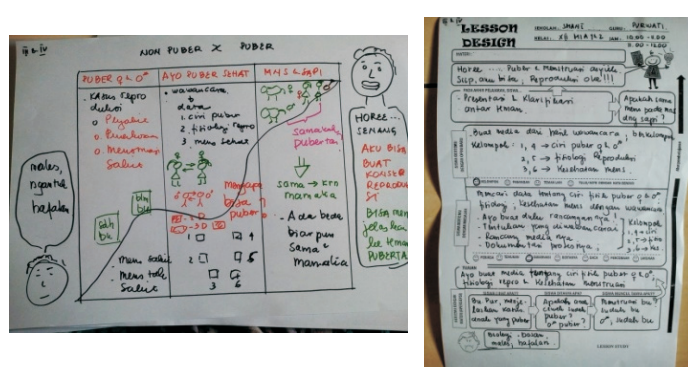

\section{Gambar 16. Lesson Design dan RPP open class III}

Hasil refleksi siswa, Pertama kali diberi tugas, semangat buat mengerjakan, dan kami join juga loh sama kelompok 4 merasa senang sekali, kebersamaan dengan teman, karena tugasnya cukup mendadak, kami mengerjakan dengan cekatan, kami dapat bersama mengerjakan, tukar pemikiran dan pendapat. Kreativitas kami juga di adu, yang katanya lomba buat presentasi di depan dosen UMM. Tak lupa juga pembina kami juga memberi semangat buat mengerjakan biar cepat selesai. "semangat rek" kata bu Pur lewat whatsapp. Waktu presentasi kami sempet deg-degan haha: tidak tahu kenapa kelompok kami yang katanya gak presentasi, tiba-tiba ditunjuk juga. Alhamdulillah senang banget bisa presentasi di depan beliau. Thanks for support mom, Mr! Walaupun tidak dsesuai harapan kami sudah berusaha juga buat bisa jadi yang terbaik. I LOVE YOU

Tugas seperti sangat bermanfaat bagi kami, karena kami belajar sambil berekreasi, menuangkan ide-ide baru dalam tugas kami. Hal yang kami dapatkan setelah kegiatan ini adalah pengalaman belajar yang menarik, tidak monoton, seru. Terlebih lagi dalam kegiatan ini kami mendapat tamu istimewa yaitu dari bapak - ibu dari Universitas Muhammadiyah Malang.

Proses Pembuatan, kami bekerja kelompok dengan baik dan kami dapat menambah wawasan dari bab "penanganan menstruasi secara sehat" serta kita dapat menambah kekompakan rasa pertemanan, menciptakan kekompakan lebih.

Dengan mempelajari seperti ini kita juga bisa mengetahui kemampuan masingmasing, dan dapat memunculkan kreatifitas, serta dapat melatih diri kita untuk mendapatkan pendapat orang lain.

Dalam membuat tugas ini, kami merasa terkejut karena sangat mendadak. Sedangkan tugas kami yang lain begitu banyak. Tetapi ini bukan suatu kendala bagi kami, justru dengan tugas ini kami merasa tertantang untuk memberikan yang terbaik. Karena dengan mengerjakan tugas ini, pengetahuan serta pengalaman kerja bersama kelompok sangat bermanfaat 
untuk kedepannya. Kami juga berusaha mencari informasi tentang ciri-ciri fisik pubertas melalui berbagai referensi.

Saat presentasi kami sedikit gugup karena ada bapak ibu dosen yang mengamati hasil kerja kami. Tetapi alhamdulillah semua berjalan dengan lancar.

Adanya Tugas biologi ini, menumbuhkan berbagai pengalaman dari kelompok kami. Saling mengingatkan, menjaga kebersamaan, belajar 2 kali lipat, belajar untuk percaya diri, dan tentunya kegiatan ini sangat berkesan, dari awla hingga akhir. Ilmu yang di dapat pun juga bertambah. Tiada kata yang dapat kami rangkai dengan indah, namun ada sejuta rasa kasih persahabatan yang kami dapatkan.

\section{Pelaksanaan Pembelajaran III dan IV (open class III dan IV)}

Pada pelaksanaan pembelajaran III atau Open Class III pada tanggal 16 Agustus 2017 pukul 10.00-11.00 wib. Open class IV tanggal 16 Agustus 2017 pukul 11.00-12.00 wib. Guru model mengkondisikan siswa pada kegiatan awal dan kegiatan inti dapat dilihat pada Gambar 17,18,19,20 dan 21. Gambar $17,18,19,20$ dan 21 terlihat siswa berantusias untuk mendiskusikan permasalahan yang telah ditentukan oleh guru model. Di luar kelas siswa berdiskusi memecahkan permaalahan antar teman. Siswa belajar untuk berkomunikasi antar teman, berkolaborasi, berpikir kritis dan berinovasi bagaimana menuangkan pemecahan permasalah dalam media 3 dimensi dan 2 dimensi. Siswa berinteraksi dengan media yang dibawa untuk menjelaskan kepada teman-temannya. Siswa sangat berkreasi dengan menuangkan konsep-konsep reproduksi mengenai ciri-ciri pubertas pria dan wanita; fisiologi reproduksi dan kesehatan menstruasi.

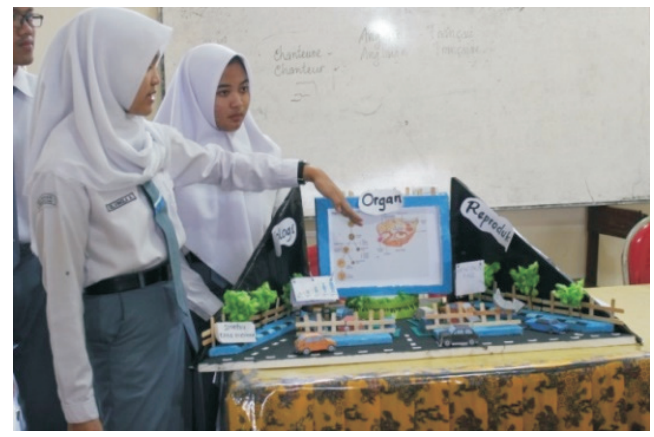

Gambar 17. Saat Presentasi

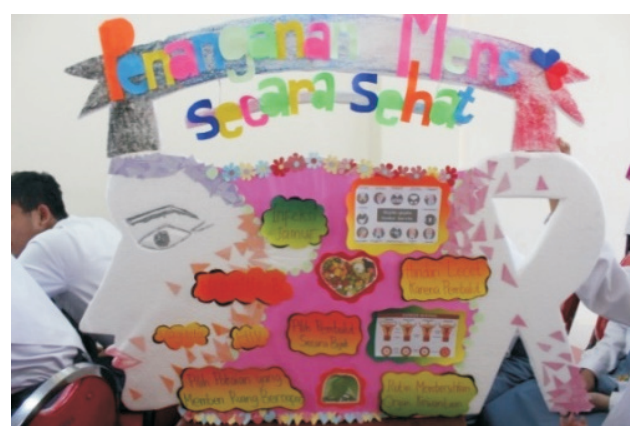

Gambar 18. Produk siswa

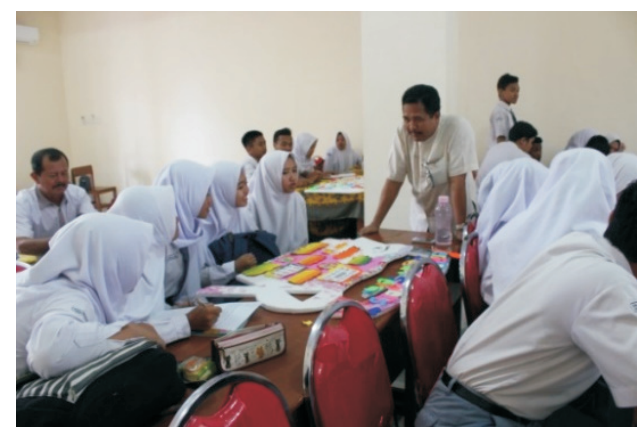

Gambar19. Saat Refleksi Pembelajaran

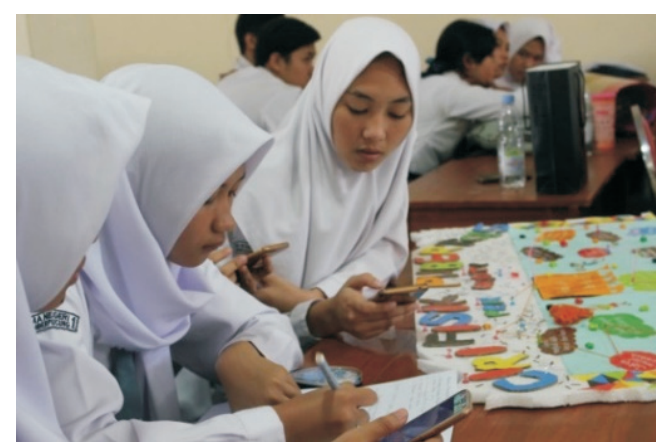

Gambar 20. Saat Diskusi 


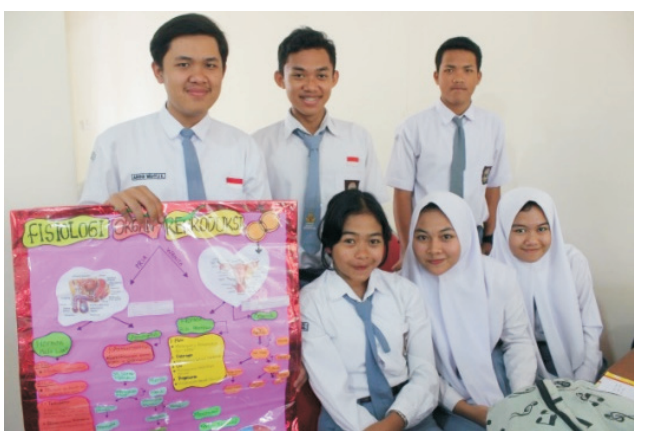

Gambar 21. Saat Presentasi

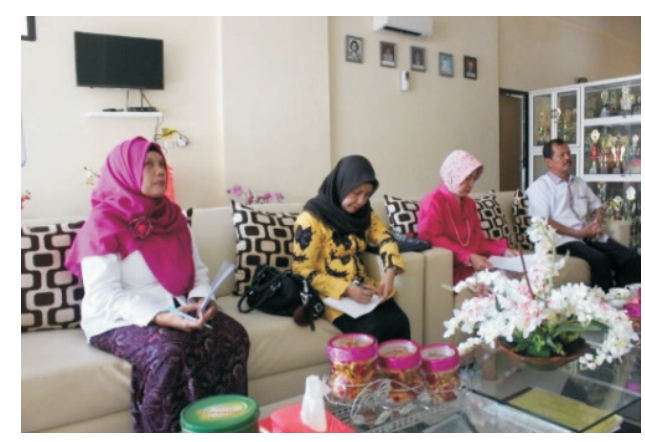

Gambar 22. Refleksi Do III dan IV

Pelaksanaan pembelajaran III dan IV berakhir segera dilaksanakan refleksi III dan IV, (Gambar 22). Hasil dari refklesi dalag sebagai berikut. Guru model dan observer, menyatakan belajar dari siswa hasil karya berupa produk ciri-ciri pubertas, fisiologi reproduksi dan kesehatan menstruasi bervariasi: media 2 dimensi, 3 dimensi dan video, hal ini menunjukkan bahwa siswa sangat luar biasa kreativitas dan berfikir kritis. Saat pembuatan media dan memecahkan masalah terbentuk kolaborasi, presentasi terlatih untuk berargumentasi. Hasil belajar yang memuaskan.

Hasil refleksi siswa, sebelum adanya model belajar berkelompok dengan menampilkan presentasi kami merasa:

1. Kurang percaya diri

2. Tegang

3. Kurang berkomunikasi dengan teman

4. Kurang kreatif membuat power point

5. Merasa canggung
6. Kurang kompak

7. Kurang aktif bertanya

Sesudah adanya model belajar berkelompok dengan menampilkan presentasi kami merasa :

1. Lebih percaya diri

2. Lebih tenang

3. Lebih komunikatif

4. Lebih kreatif

5. Tidak canggung

6. Lebih kompak

7. Aktif bertanya

8. Dapat mengetahui kemampuan teman

Dalam membuat presentasi ini, kami mencari beberapa materi yang berkaitan dengan fisiologi organ reproduksi pada laki-laki dan perempuan di berbagai sumber, salah satunya di internet dan buku. Setelah kami baca, kami menyimpulkan dan memahami materi tersebut dengan membuat presentasi agar mudah dipahami oleh teman-teman.

- Sebelum adanya model belajar dengan cara presentasi kami merasa:

1. Kurang memahami.

2. Kuramg percaya diri

3. Kurang menata kata-kata yang akan diucapkan

4. Pasif dan merasa canggung

5. Lebih percaya pada buku panduan yang diberikan

6. Kurang kompak

7. Takut salah dalam materi yang disampaikan

Sesudah adanya model belajar dengan cara presentasi kami merasa

1. Pengetahuan menjadi luas

2. Percaya diri yang tinggi

3. Lebih aktif dalam bertanya

4. Kekompakan kelompok

5. Lebih kreatif

6. Optimis 
Kita dari kelompok 3 yang membahas tentang ciri fisik pubertas, banyak cerita yang kami alami dalam proses pembuatan mind map. Kita membagi tugas untuk mengerjakan project ini. seperti membuat inti pembahasan, membuat properti dan juga ide-ide lainnya. Kita mengerjakan sepulang sekolah, berhubung sekolah kami full day, jadi kami biasanya juga mengerjakan di sela-sela pelajaran (waktu istirahat/jamkos).

Kendala yang kami hadapi dalam mengerjakan project ini yang pertama adalah waktu, kami mengalami kesulitan dalam hal waktu karna kita mengerjakan project ini hanya dalam waktu 1 hari sehingga hasilnyapun kurang memuaskan mungkin dilain waktu bila ada tugas yang sama kami akan mengerjakannya dengan lebih serius.

Menurut pendapat kelompok kami pembelajaran dengan metode diskusi seperti ini lebih efisien dikarenakan lebih mudah diingat dan tidak membosankan dan dapat melatih kreatifitas, menambah wawasan, mengasah otak, melatih mental dan sebagainya.

Guru biologi kami memberikan tugas untuk membuat media pembelajaran memalui mind map/Mading. Pertama, kami mengumpul informasi /materi bab ciri fisik pubertas. Selanjutnya, kami merencanakan apa yang akan kami tuangkan ke dalam mind map kami. Berikutnya, mulai mengerjakan apa yang telah kami rencanakan. Hal, pertama yang kami kerjakan yaitu membuat judul, lalu menulis materi yang kita bahas. Kami juga membuat hiasanhiasan untuk memperindah mind map kami. Yang kedua, kita mulai menyusun materi/ menempelnya pada sterofom sebagai media utama kami.
Menurut pendapat kami, dengan metode pembelajaran seperti ini mempermudah kita untuk memahami dan mendalami materi. Selain itu, dapat mengasah kreativitas kami.

\section{Refleksi Kerja Project:}

1. Menentukan Tema

Kita membahas materi dalam tema untuk menentukan alur pemahaman materi. Selain itu, kita juga membagi materi setiap amggota.

2. Menentukan Konsep

Pertama kita menggunakan konsep 3D dari berbagai pilihan seperti jalan raya, mall, bioskop. Kami menggabungkannya satu konsep menjadi bioskop mobil

3. Penentuan material dan pengerjaan

Menentukan material yang dibutuhkan dan sesuai dengan kebutuhan.

Kami mengerjakannya dengan kurun waktu 3 hari dengan mengerjakan dateline. Selain itu, kita juga memahami materi dan mengerjakannya dengan menambah motivasi seiring dengan proses pengerjaan. Kami berharap kritik dan saran yang dapat membangun untuk tugas selanjutnya yang lebih baik.

Dalam kerja kelompok ini kami mengalami berbagai kendala, salah satunya adalah waktu yang diberikan terlalu singkat juga jadwal pulang sekolah terlalu sore membuat kami sulit mencari waktu untuk berdiskusi dengan teman-teman. Disamping itu, banyak tugas lain yang harus kami kerjakan dan kumpulkan.

Dalam pembuatan karya ini kami mendapat tema "Fisiologi Organ Reproduksi Pria Dan Wanita" kami memilih media kertas karton tebal. Dalam pembuatan pembuatan karya ini kami lebih memahami apa yang kami pelajari karena dalam prosesnya pembuatannya kami di tuntut untuk 
memahami materi tersebut. Selain itu dengan menggunakan media seperti ini membuat kami lebih memahami dan tidak merasa bosan.

\section{Refleksi Tugas}

1. Untuk tugas kali ini saya dan temanteman mempunyai gagasan ide yang berbeda dari teman-teman kami yang lain untuk menyampaikan materi yang kami buat.

2. Kami memilih media short film, karena menurut kami media ini tidak ada yang menyamai dan juga bisa dikatakan untuk menghemat biaya.

Mengapa Kami mengatakan hemat biaya karena menurut kami tidak semua tugas harus mengeluarkan badget, kita bisa memanfaatkan media yang ada seperti hp, laptop, gadget dari media tersebut kita bisa mengembangkan lagi.

Selain itu di masa sekarang banyak dari kalangan remaja yang cara belajarnya memilih media audio visual, karena menurut mereka cara ini akan cepat mudah dipahami, di mengerti dan yang pasti bisa belajar dimanapun kita berada.

Cara seperti ini sangat efisien dan kekinian. Kami membuat mading ini dengan tema "Penanganan Menstruasi secara Sehat" kami membuat rhi dengan waktu yang sangat singkat hanya satu hari.

Deskripsi dari bentuk mading kami menggambarkan sosok wanita dari smaping dan simbol peta berwarna pink (merah muda) sebagai logo kanker pada wanita.

Di dalam mading kami menjelaskan: gejala-gejala penyakit serviks (kanker serviks) beserta cara penanganan saat menstruasi dan contoh-contoh penyakit dan ditimbulkan dari buruknya penanganan saat menstruasi.

Dengan adanya tugas ini kami menjadi lebih tertantang untuk menguasai materi yang telah kami presentasikan dan terlatih untuk berbicara di depan umum. Adanya kreativitas dan ide baru membuat kami barsaing secara sehat dengan kelompok yang lain.

\section{Respon siswa terhadap pembelajaran} praktik kolaboratif berbasis LS

Pada akhir pembelajaran siswa melakukan refleksi tentang pelaksanaan Lesson Study. Hasil refleksi dari 24 kelompok menyatakan bahwa senang dengan pelaksanaan Lesson StudyLearning Community pada Pengajaran Biologi. Siswa yang suka menyatakan bahwa dengan pembelajaran tersebut siswaberkreatif dalam merancang produk berupa media reproduksi. Grafik batang tentang respon siswa disajikan pada Gambar 22.

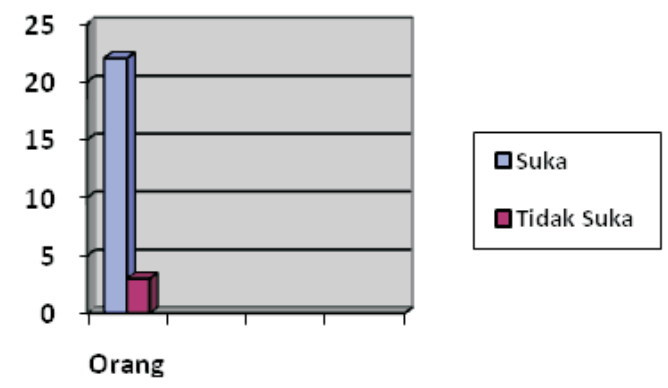

\section{Gambar 22. Grafik Batang tentang respon siswa perkelompok setelah pelaksanaan Lesson Study}

Temuan pada saat plan, do dan see, siswa dilatih untuk membentuk komunitas belajar sehingga bisa berkolaborasi, merancang pembelajaran yang inovatif, kreatif dan menyenangkan, belajar dari teman. Hal ini sesuai dengan harapan pendidikan yang abad 21, yaitu guru yang mampu jadi pembelajar sepanjang karir, mampu bekerja, belajar dengan dan dari kolega serta mampu berkomunikasi baik langsung ataupun tidak langsung dengan menggunakan teknologi untuk mendukung proses pembelajaran yang bermutu 
(Hargreaves, 2000; Darling, 2006). Guru yang professional tidak lagi sekedar mengajar tetapi juga sebagai pembelajar (Andriani, 2010). Kegiatan Lesson Study tidak hanya kegiatan yang pertemuan antar guru tetapi merupakan program pembinaan profesionalisme guru melalui pengkajian pembelajaran secara kolaboratif dan berkelanjutan berdasarkan prinsip kolegialitas dan mutual learning (Riyati, 2007).

Pembelajaran kolaboratif didasarkan pada teori zona perkembangan milik Vygotsky dan teori komunikasi oleh Dewey. Di dalam berdiskusi yang harus dibangun oleh siswa adalah 'saling belajar'. Pada Lesson Study Learning Community yang ditekankan adalah hubungan saling belajar (hubungan saling mendengarkan), pembelajaran otentik (pembelajaran yang sejalan dengan karakteristik mata pelajaran dan pembelajaran yang terdapat lompatan (jumping), yaitu pembelelajaran yang bersifat kreatif dan menantang (Sato, 2014). Guru saling berkolaborasi, membentuk Learning Community, pembelajaran yang menyenangkan. Program LS bukan untuk mengkritik guru tetapi mengamati bagaimana siswa belajar.

\section{SIMPULAN}

Pelaksanaan Lesson Study di SMAN 1 Sumberpucung dapat disimpulkan sebagai berikut. RPP (Lesson Design) danmateri (Chapter Design) pembelajaran LS disusun secara kolaboratif oleh guru. Chapter Design, Lesson Design dan RPP 1 lembar telah terbentuk, maka guru model siap untuk melakukan pembelajaran di kelas XII dengan didampingi oleh beberapa observer (dari guru SMA Negeri 1 Sumberpucung).
Fokus saat pelaksanan pembelajaran, pada peserta didik adalah kemampuan berpikir kritis, kolaboratif, komunikasi dan berkreasi alam menjelaskan materi reproduksi dengan 3 topik, yaitu: ciri-ciri pubertas pria dan wanita; fisiologi reproduksi; dan kesehatan menstruasi dengan menggunakan media yang telah dibuat perkelompok. Guru model melakukan apersepsi tentang kasuskasus tentang reproduksi wanita dan pria. Peserta didik dibagi 6 kelompok, yaitu kelompok 1 dan 4 membahas ciri-ciri pubertas pria dan wanita, kelompok 2 dan 5 membahas fisiologi reproduksi, kelompok 3 dan 6 membahas tentang kesehatan reproduksi Praktik kolaboratif dalam pembelajaran berbasis LS dilakukan 4 kali pertemuan (4 siklus), siklus I dengan metode Problem Base Learning; siklus II dengan Project Base Learning dengan membuat media power point; siklus III dan IV menggunakan Project Base Learning dengan membuat media $2 / 3$ dimensi. Hasil refleksi siswa terlatih berkomunikasi, berkolaborasi, berkreasi dan berpikir kritis.Respon siswa 99\% sangat suka dengan metode project karena terlatih percaya diri, berkreasi, berkomunikasi dengan teman.

\section{DAFTAR PUSTAKA}

Andriani, D.E. 2010.Mengembangkan Profesionalitas Guru Abad 21 melalui Program Pembimbingan yang Efektif. Manajemen Pendidikan. 2: 78-92.

Darling, Linda,H. 2006. Contructing $21^{\text {st }}$ Century teacher Education. Journal of Teacher Education. 57: 300-314.

Hargreaves, A \& Fulan, M. 2000. Mentoriy in The New Millenium. ProQuest Education. 39 (1):50-56. 
Masaaki, S. 2014. Dialog dan Kolaborasi di Sekolah Menengah Pertama Praktek Learning Community. Pelita. JICA.

Riyati, S. 2007. Sistem Pembinaan Profesional Guru Pendidikan IPA melalui Lesson Study. Bandung. UPI.

Rustaman,, et.al, 2003, Common Teks Book Strategi Belajar Mengajar Biologi (Edisi Revisi). Bandung. JICA-IMSTEP-UPI

Sato, M. 2014. Mereformasi Sekolah. Konsep dan Praktek Komunitas Belajar. Pelita. JICA

Sato, E \& Atendo, M. 2015. Lesson Study for Learning Community (LSLC): Conceptualising Teachers' Practice within A Sosial Juctice Perspective. Discourse Studies in The Cultural Politic of Education. 36(6):795-807. 


\title{
PENINGKATAN HASIL BELAJAR BILANGAN BERPANGKAT DENGAN MODEL PROBLEM POSING PADA SISWA KELAS IX SMP NEGERI SATU ATAP PESANGGRAHAN 2 BATU
}

\author{
Sudiyono \\ SMP Negeri Satu Atap Pesanggrahan 2 Batu \\ Email: sd_dion@yahoo.co.id
}

\begin{abstract}
ABSTRAK
Masih kurang minatnya peserta didik dalam belajar khususnya pelajaran matematika, salah satu sebab adalah metode yang digunakan oleh guru masih konvensional dan peserta didik bekerja secara individu, sehingga peserta didik yang kurang mampu kesulitan dalam memahami konsep dengan benar. Tujuan dari penelitian ini adalah untuk meningkatkan hasil belajar bilangan berpangkat dengan model problem posing pada peserta didik kelas IX SMP Negeri Satu Atap Pesanggrahan 2 Batu. Penelitian ini menggunakan desain Penelitian Tindakan Kelas (Classroom Action Research), pendekatan yang digunakan dalam penelitian ini adalah pendekatan kualitatif yaitu penelitian yang datanya tanpa menggunakan teknik statistik. Penelitian tindakan kelas ini dilaksanakan dalam dua siklus. Setiap siklus terdiri dari perencanaan, tindakan, observasi dan refleksi. Berdasarkan data yang diperoleh dari pelaksanaan tindakan mulai siklus 1 sampai dengan siklus 2 dan berdasarkan hasil obsevasi tiap-tiap siklus terjadi peningkatan hasil belajar yaitu peserta didik yang mendapat nilai kurang dari KKM dari 17 peserta didik menjadi 7 peserta didik, mengalami peningkatan peserta didik yang mendapat nilai memenuhi KKM dari 18 menjadi 27 peserta didik, dan rata-rata tes peserta didik dari 62,29 menjadi 71,76 mengalami kenaikan $2,47 \%$, serta prosentase ketuntasan juga mengalami peningkatan dari 48,6\% menjadi 79,4\% meningkat $30,8 \%$. Hal ini menunjukkan bahwa dengan pendekatan model problem posing dapat meningkatkan hasil belajar peserta didik khususnya pada materi bilangan berpangkat.
\end{abstract}

Kata Kunci: Peningkatan hasil belajar, Bilangan berpangkat, Problem Posing

\begin{abstract}
The lack of student's study interest especially on mathematics, one of the reason is the method is still conventional and students work individually, with the result that students harder to understanding the concept correctly. The purpose of this research is improving learning outcome on exponential numbers with problem posing model in $3^{\text {rd }}$ years students on State Junior High School Batu. This research using Classroom Action Research design and qualitative approach, which is the research that not using statistics technique. This Classroom Action Research executed in two cycle. Every cycle consist of planning, action, observation, and reflection. Based on data that obtained from the $1^{\text {st }}$ cycle until $2^{\text {nd }}$ cycle and based on observation from every cycle there is an achievement increase that is students that having under the minimum learning mastery standard from the initial is 17 students increase to 7 students, then there is increase the numbers of students that having on the minimum learning mastery standard from 18 to 27 students, and the average of students' test from 62,29 to 71,76 (increasing $2,47 \%$ ), so the percentage of learning mastery increased from $48,6 \%$ to $79,4 \%$ increase for about $30,8 \%$. This shows that Problem Posing approach can increasing student's study result especially on exponential numbers subject.
\end{abstract}

Keyword: Increase of study result, Exponential numbers, Problem Posing 


\section{PENDAHULUAN}

Matematika masih dianggap momok bagi peserta didik, dan peserta didik masih beranggapan bahwa matematika adalah pelajaran yang sulit. Hal ini disebabkan masih banyak guru dalam menyampaikan pembelajaran secara konvensional dan kurang memahami dunia anak.

Matematika adalah salah satu mata pelajaran dan merupakan ilmu dasar (basic science) yang penting baik sebagai alat bantu, pembimbing pola pikir maupun sebagai pembentuk sikap, maka dari itu matematika diharapkan dapat dikuasai oleh peserta didik di sekolah. Namun pelajaran matematika selalu dianggap sulit dan ditakuti oleh peserta didik sehingga sangat berdampak pada rendahnya prestasi belajar peserta didik, hal ini juga terjadi di SMP Negeri Satu Atap Pesanggrahan 2 Batu berdasarkan hasil ujian nasional tahun pelajaran 2016/2017.

Masih kurang minatnya peserta didik dalam belajar khususnya pelajaran matematika, salah satu sebab adalah metode yang digunakan oleh guru masih konvensional dan peserta didik bekerja secara individu, sehingga peserta didik yang kurang mampu kesulitan dalam memahami konsep dengan benar.

Berdasarkan observasi awal dengan melalui wawancara bersama guru mata pelajaran matematika kelas IX diSMP Negeri Satu Atap Pesanggrahan 2 Batudan pengalaman peneliti bahwa penguasaan peserta didik terhadap materi pelajaran matematika masih tergolong rendah salah satunya pada materi bilangan berpangkat. Ini terlihat dengan rata-rata hasil ulangan harian semester genap tahun pelajaran $2016 / 2017$ yang tuntas hanya $48 \%$ dan yang tidak tuntas 52\% dengan KKM yang ada di SMP Negeri Satu Atap Pesanggrahan 2 Batu kelas IX yaitu 67,00.
Peserta didik masih sulit memahami konsep bilangan berpangkat sehingga peserta didik tidak dapat mengerjakan soal dengan benar dan tepat. Selain itu peserta didik juga masih sulit mengerjakan soal yang sedikit berbeda dengan contoh soal yang diberikan oleh guru.

Salah satu pokok bahasan yang harus dikuasai peserta didik dalam mata pelajaran matematika di SMP adalah bilangan berpangkat. Dijabarkan dalam kompetensi dasar yaitu kompetensi dasar 5.1 Mengidentifikasi sifat-sifat bilangan berpangkat dan bentuk akar (BSNP, 2006). Peserta didik dikatakan tuntas pada kompetensi ini apabila mendapat nilai di atas KKM ( > 67 ), dan ketuntasan klasikal 75\%.

Selama ini peneliti dalam melakukan proses pembelajaran masih bersifat konvensional dan peserta didik bekerja secara individu. Kegiatan peserta didik setelah diterangkan mengerjakan soal-soal pada buku paket, dengan pembelajaran konvensional terbukti kurang efektif. Merefleksi proses pembelajaran yang telah dilakukan, maka penulis mencoba alternatif pemecahan lain dalam proses pembelajaran, yaitu perlu adanya strategi pembelajaran yang bersifat mengaktifkan peserta didik dengan pendekatan pembelajaran bermakna dan menyenangkan. Pada model ini peran peserta didik cukup besar karena pembelajaran tidak lagi berpusat pada guru tetapi pada peserta didik. Guru memulai kegiatan belajar mengajar dengan menjelaskan kegiatan yang akan dilakukan dan mengorganisir kelas untuk kegiatan.

Dalam penelitian ini penulis mencoba menggunakan model problem posing. Kelebihan model problem posing memberikan pembelajaran yang 
menekankan pemikiran kritis demi tujuan pembebasan dalam belajar (Huda, 2013).Pembelajaran dengan problem posing pada penelitian ini menekankan pada pembentukan atau perumusan soal oleh siswa secara berkelompok. Langkahlangkah pembelajaran problem posing secara berkelompok adalah : (1) guru menyampaikan tujuan pembelajaran dan memotivasi siswa untuk belajar, (2) guru menyajikan informasi baik secara ceramah atau tanya jawab selanjutnya memberi contoh cara pembuatan soal dari informasi yang diberikan, (3) guru membentuk kelompok belajar antara 4-5 siswa tiap kelompok yang bersifat heterogen baik kemampuan, ras dan jenis kelamin, (4) selama kerja kelompok berlangsung guru membimbing kelompok-kelompok yang mengalami kesulitan dalam membuat soal dan menyelesaikannya. Sebelum bekerja kelompok siswa di awali dengan kerja secara individu (berpasangan) dahulu baru berkelompok, dan (5) guru mengevaluasi hasil belajar tentang materi yang telah dipelajari dengan cara masingmasing kelompok mempersentasikan hasil pekerjaannya.

Melihat begitu pentingnya permasalahan diatas, maka peneliti merasa perlu segera menyelesaikan dalam penelitian tindakan kelas, mengingat kompetensi ini merupakan prasyarat dalam mempelajari kompetensi berikutnya.

Berdasarkan latar belakang di atas, peneliti mengadakan penelitian tindakan kelas dengan judul: Peningkatan Hasil Belajar Bilangan Berpangkat dengan model Problem Posing pada Peserta didik Kelas IX SMP Negeri Satu Atap Pesanggrahan 2 Batu. Rumusan masalah dalam penelitian ini adalah: Bagaimana meningkatkan hasil belajar bilangan berpangkat dengan model problem posing pada peserta didik kelas IX SMP Negeri Satu Atap Pesanggrahan 2 Batu?. Tujuan dari penelitian ini adalah untuk meningkatkan hasil belajar bilangan berpangkat dengan model problem posing pada peserta didik kelas IX SMP Negeri Satu Atap Pesanggrahan 2 Batu.

Meningkatkan hasil belajarpeserta didik sangat tergantung bagaimana proses belajar yang dilakukan oleh peserta didik yang sedang belajar itu sendiri. Sudjana (1991), belajar adalah perubahan yang relatif permanen dalam suatu kecenderungan tingkah laku sebagai hasil dari praktek dan latihan. Sedangkan menurut Slameto (2003), mengemukakan bahwa belajar adalah suatu proses yang dilakukan untuk memperoleh suatu perubahan tingkah laku yang baru secara keseluruhan sebagai hasil pengalaman sendiri dalam interaksi dengan lingkungannya.

Dalam uraian di atas dapat disimpulkan bahwa belajar adalah suatu proses perubahan tingkah laku yang dilakukan secara sadar, bersifat permanen sebagai hasil pengalaman sendiri dalam interaksi dengan lingkungannya. Jadi hasil dari belajar adalah adanya perubahan tingkah laku.

Hasil belajar yang dicapai oleh peserta didik ditunjukkan oleh perubahanperubahan dalam bidang pengetahuan atau pemahaman, keterampilan, analisis, sintesis, evaluasi, serta nilai dan sikap. Perubahan yang dihasilkan dari belajar dapat berupa perubahan persepsi dan pemahaman, yang tidak selalu dilihat sebagai tingkah laku. Dalam belajar, terdapat tiga masalah pokok, yaitu: (1) masalah mengenai faktor-faktor yang mempengaruhi terjadinya belajar; (2) masalah mengenai bagaimana belajar itu berlangsung dan prinsip mana yang 
dilaksanakan; (3) masalah mengenai hasil belajar. Dua masalah pokok yang pertama berkenaan dengan proses belajar yang sangat mempengaruhi kepada masalah pokok ketiga. Dengan demikian bagaimana terjadinya proses belajar akan menentukan hasil belajar seseorang (Hudoyo,1990).

Jadi hasil belajar matematika merupakan hasil belajar peserta didik dalam suatu proses pembelajaran dengan waktu tertentu. Setiap proses belajar mengajar, keberhasilannya diukur dari sejauh mana hasil belajar yang dicapai peserta didik, disamping diukur dari segi prosesnya

Sterling (2005), pangkat adalah angka kecil yang dituliskan di sebelah kanan atas bilangan dasar. Penulisan pangkat lebih kecil dari penulisan bilangan dasarnya. Bilangan dasar bisa berupa semua bilangan nyata. Pangkat juga bisa berupa bilangan nyata. Pangkat bisa berupa bilangan positif, negatif, pecahan, dan akar. Menurut Bobrow(2004), pangkat adalah bilangan positif atau negatif yang diletakkan di sebelah kanan atas sebuah bilangan pokok. Notasi bilangan berpangkat dapat dituliskan: $x^{n}$ $=x . x . x . x \ldots n$ kali, dengan $x$ bilangan dasar dan $n$ pangkat. Pernyataan $x^{n}$ bisa berupa semua bilangan nyata dan $n$ juga bisa berupa semua bilangan nyata, tetapi keduanya tidak bisa berupa angka 0 pada waktu bersamaan $\left(0^{0}\right)$, misal: $3^{5}=3.3 .3$. 3. $3=243$.

Problem posing adalah istilah dalam bahasa Inggris yaitu dari kata "problem" artinya masalah, soal/persoalan dan kata "pose" yang artinya mengajukan (Echols dan Shadily, 1995). Setiawan (2004) mengatakan pembentukan soal atau pembentukan masalah mencakup dua kegiatan yaitu: (1) pembentukan soal baru atau pembentukan soal dari situasi atau dari pengalaman peserta didik. (2) pembentukan soal dari soal yang sudah ada.

Hasil penelitian Silver dan Cai dalam Surtini (2003) menunjukkan bahwa kemampuan pembentukan soal berkorelasi positif dengan kemampuan memecahkan masalah. Dengan demikian kemampuan pembentukan soal sesuai dengan tujuan pembelajaran matematika di sekolah sebagai usaha meningkatkan hasil pembelajaran matematika dan dapat meningkatkan kemampuan peserta didik. Dari sini kita peroleh bahwa pembentukan soal penting dalam pelajaran matematika guna meningkatkan prestasi belajar matematika peserta didik dengan membuat peserta didik aktif dan kreatif.

Dari uraian di atas bisa katakan bahwa problem posing merupakan suatu pembentukan soal atau pengajuan soal yang dilakukan oleh peserta didik dengan cara membuat soal tidak jauh beda dengan soal yang diberikan oleh guru ataupun dari situasi dan pengalaman peserta didik itu sendiri.

Pembelajaran dengan problem posing pada penelitian ini menekankan pada pembentukan atau perumusan soal oleh peserta didik secara berkelompok. Setiap selesai pemberian materi guru memberikan contoh tentang cara pembuatan soal dan memberikan informasi tentang materi pembelajaran dan bagaimana menerapkannya dalam problem posing secara berkelompok.

Langkah-langkah pembelajaran problem posing secara berkelompok adalah (1) guru menyampaikan tujuan pembelajaran dan memotivasi peserta didik untuk belajar; (2) guru menyajikan informasi baik secara ceramah atau tanya jawab selanjutnya memberi contoh cara pembuatan soal dari informasi yang 
diberikan; (3) guru membentuk kelompok belajar antara 4-5 peserta didik tiap kelompok yang bersifat heterogen baik kemampuan, ras dan jenis kelamin. Selama kerja kelompok berlangsung guru membimbing kelompok-kelompok yang mengalami kesulitan dalam membuat soal dan menyelesaikannya. Sebelum bekerja kelompok peserta didik di awali dengan kerja secara individu (berpasangan) dahulu baru berkelompok: (1) guru mengevaluasi hasil belajar tentang materi yang telah dipelajari dengan cara masing-masing kelompok mempersentasikan hasil pekerjaannya; (2) guru memberi penghargaan kepada peserta didik atau kelompok yang telah menyelesaikan tugas yang diberikan dengan baik.

\section{METODE}

Penelitian ini menggunakan desain Penelitian Tindakan Kelas (PTK), pendekatan yang digunakan dalam penelitian ini adalah pendekatan kualitatif yaitu penelitian yang datanya tanpa menggunakan teknik statistik. Subyek penelitian peserta didik kelas IX SMP Negeri Satu Atap Pesanggrahan 2 Batu, sedangkan lokasi penelitian di SMP Negeri Satu Atap Pesanggrahan 2 Batu. Jl. Cempaka Atas No. 01 Pesanggrahan Batu.

Penelitian tindakan kelas ini dilaksanakan dalam dua siklus. Setiap siklus terdiri dari perencanaan, tindakan, observasi dan refleksi. Tiap siklus terdiri dari 4 tahap yaitu perencanaan, pelaksanaan, pengamatan, dan refleksi.

Adapun tahapanan penelitian dilakukan sebagai berikut:

\section{a. Tahap Perencanaan (Planning)}

Pada tahap perencanaa, penulis menyiapkan perangkat pembelajaran dan perangkat penilaian, yaitu: (1) penyusunan RPP, 2) lembar kerja peserta didik, (3) menyusun intrumen tes dan non tes, (4) instrumen pengamata, (5) intrumen angket peserta didik, (6) soal uraian.

\section{b. Tahap Pelaksanaan (Action)}

Penyajian materi ini dilakukan oleh peneliti sedangkan kolabolator sebagai pengamat untuk mengamati aktifitas kegiatan belajar mengajar yang terjadi di kelas. Materi yang disajikan sesuai siklus yang direncanakan dengan kompetensi dasar: Mengidentifikasi sifat-sifat bilangan berpangkat dan bentuk akar. Pertemuan pertama dengan indikator menjelaskan pengertian bilangan yang berpangkat positif serta sifat-sifatnya dan pertemuan kedua menjelaskan pengertian bilangan yang berpangkat negatif atau nol. Kegiatan problem posing secara berkelompok dilakukan setelah guru memberikan contoh, maka peserta didik dalam kelompok yang heterogen membuat soal dan menyelesaikannya berdasarkan pemahaman kelompok terhadap materi yang disajikan oleh guru dan selanjutnya mempersentasikan hasil kerja kelompok mereka.

\section{c. Tahap Observasi}

Pengamatan dilakukan kolabolator dalam bentuk observasi dilakukan dengan maksud untuk mendokumentasikan hal-hal yang berkaitan dengan pemberian tindakan kegiatan guru dan kegiatan tiap kelompok peserta didik. Pengamatan dilakukan selama proses belajar mengajar berlangsung dengan menggunakan intrumen pengamatan. Tindakan ini dimaksudkan untuk mengumpulkan data secara keseluruhan . 


\section{d. Tahap Refleksi}

Refleksi merupakan kegiatan menganalisis, memahami, menjelaskan dan menyimpulkan hasil pengamatan yang dilakukan antara peneliti dan kolaborator. Dalam kegiatan ini menggunakan indikator keberhasil yang telah direncanakan. Dilakukan sebagai upaya untuk memahami proses dan hasil yang dicapai sebagai akibat dari tindakan yang dilakukan. Hasil yang diperoleh pada kegiatan refleksi ini merupakan informasi tentang apa yang dilakukan selanjutnya yang dapat dijadikan dasar dalam melakukan rencana berikutnya.

Teknik pengumpulan data, data yang diperoleh dalam penelitian ini adalah data kuantitatif dan data kualitatif, melalui pengambilan data berupa tes yang dilakukan setelah akhir siklus dan non tes. Teknik pengumpulan data non tes pada penelitian ini adalah observasi yang diarahkan pada pengumpulan data yang berkaitan dengan proses pembelajaran tentang bilangan berpangkat dengan model problem posing.

Teknik Analisis Data, data yang telah terkumpul selanjutnya dianalisis menggunakan analisis data deskriptif kualitatif untuk intrumen non tes dengan kriteria yang telah ditentukan dan data kuantitatifdengan cara mencari nilai rata-rata (mean) dan ketuntasan belajar peserta didik untuk kemudian dibandingkan mulai dari sebelum diberi tindakan dengan model problem posing sampai setelah diberi tindakan pada akhir siklus untuk data tes.

Indikator Keberhasilan, berdasarkan ketentuan dan keadaan peserta didik di sekolah tempat penelitian dilakukan maka indikator keberhasilan dalam penelitian ini, jika minimal $75 \%$ peserta didik yang diajar dengan menggunakan pembelajaran model problem posing dapat memperoleh nilai $>67$.

\section{HASIL DAN PEMBAHASAN}

Riedesel, Schwarzt, dan Clements (dalam Suryadi) dalam kegiatan yang bersifat problem posing (pengajuan soal), anak memperoleh kesempatan untuk mengembangkan kemampuannya mengidentifikasi fakta-fakta yang diberikan serta permasalahan yang bisa muncul dari fakta-fakta tersebut. Huda (2013) bahwa problem solving (pengajuan soal) melibatkan tiga keterampilan dasar, yaitu menyimak (listening), berdialog (dialogue), dan tindakan (action).

Problem posing (pengajuan soal) yang dimaksud dalam penelitian ini adalah suatu pendekatan pembelajaran matematika dengan cara pemberian tugas kepada peserta didik untuk menyusun atau membuat soal berdasarkan situasi yang tersedia dan menyelesaikan soal tersebut.

Penelitian ini dilaksakan dalam dua siklus. Sedangkan masa Classroom Action Research di bagi dua siklus diambil berdasarkan rentang waktu dua pekan. Setiap siklus terbagi dalam 2 pertemuan setiap pertemuan dengan durasi waktu $2 \mathrm{x}$ 45 menit. Penelitian ini juga berkolaborasi dengan guru-guru yang mengajar bidang studi matematika.

Hasil-hasil penelitian pada tiap siklus dapat diinterprestasikan sebagai berikut.

Pada siklus 1, pertemuan pertama peserta didik diajak untuk mendiskusikan kompetensi dengan indikator mengidentifikasi sifat-sifat operasi pada bilangan berpangkat bulat dan pertemuan ke dua mengubah bilangan berpangkat negatif menjadi bilangan berpangkat positif dan sebaliknya. Guru menjelaskan secara 
klasikal, kegiatan problem posing secara berkelompok dilakukan setelah guru memberikan contoh, maka peserta didik dalam kelompok yang heterogen membuat soal dan menyelesaikannya berdasarkan pemahaman kelompok terhadap materi yang disajikan oleh guru pada lembar kerja yang telah disiapkan. Langkah pertama peserta didik membuat soal dan menjawab secara individu kemudian dibahas dalam kelompok, dan selanjutnya mempersentasikan hasil kerja kelompok mereka. Selama peserta didik melaksanakan kegiatan pembelajaran, peneliti dan kolaborator melakukan pendampingan kepada peserta didik dengan maksud apabila ada kelompok yang mengalami kesulitan dapat dibantu seperlunya. Setelah proses pembelajaran pada pertemuan kedua peserta didik diberi angket dan tes tertulis, dan di akhir siklus I peneliti bersama kolaborator menganalisis data yang diperoleh selama pelaksanaan tindakan siklus 1 .

Dari pengamatan yang dilakukan guru dan kolaborator selama proses pembelajaran berlangsung dapat dicatat hal-hal sebagai berikut: pada awal siklus I masih banyak peserta didik yang bingung, kurang memahami bagaimana cara menyusun soal, soal yang tersusun hampir seluruhnya mirip contoh yang diberikan guru hanya berbeda bilangan. Hanya beberapa kelompok yang sudah bisa bekerja sama, dan saling membantu antar anggota kelompok. Guru dalam pendampingan masih belum merata ke seluruh kelompok sehingga masih ada kelompok yang nampak kesulitan dalam memahami tugas yang dimaksud. Peserta didik terlihat kesulitan dalam menyusun soal karena dilakukan secara individu terlebih dahulu, hal ini disebabkan tidak semua peserta didik terbiasa dan mampu membuat soal sendiri. Kelas sebagai penelitian ini adalah kelas yang heterogen, sehingga kemampuan peserta didik tidak sama pada saat peserta didik menyusun soal dimana peserta didik yang pandai dapat menyusun soal lebih cepat dari temannya, serta membuat kunci jawaban dan menyusun soal berikutnya.

Kegiatan pada siklus 2, berdasarkan hasil refleksi siklus 1, maka pada siklus 2, langkah pertama peserta didik membuat soal dan menjawab secara berpasangan kemudian dibahas dalam kelompok, dan hasil kelompok ditukar dengan kelompok lain untuk dikerjakan dan apabila kelompok yang lain tidak bisa mengerjakan maka kelompok pembuat soal harus menjelaskan, termasuk membimbing dan kemudian memeriksa kebenaran hasilnya. Selanjutnya mempresentasikan hasil kerja kelompok mereka.

Dari pengamatan yang dilakukan guru dan kolaborator selama proses pembelajaran berlangsung dapat dicatat hal-hal sebagai berikut: pada siklus 2 peserta didik sudah nampak lebih aktif dalam menyusun soal karena dilakukan secara berpasangan, hal ini dapat dilihat dari keseriusan peserta didik dalam menyusun dan menjawab soal serta soal lebih variatif. Pada siklus 2 ini lebih nampak interaksi antar peserta didik tidak hanya dalam kelompok saja tetapi juga dengan kelompok lain,banyak perubahan positif yang diperoleh, yaitu peserta didik merasa percaya diri dalam mengajukan model soal yang ia buat baik dengan pasangannya maupun dengan kelompok. Dengan menukar soal secara silang antar kelompok, terlihat ada interaksi antar peserta didik, dan persaingan sehinga pada saat membuat soal ada keingin soal yang dibuatnya sulit dan orang lain tidak dapat menjawabnya. Ia merasa bangga 
bila hal ini terjadi, begitu juga apabila pada saat guru meminta dia agar menjelaskan soal tersebut kepada teman yang akan menjawab. Demikian juga sebaliknya, bila yang menjawab soal dapat dengan mudah menyelesaikan soal yang dibuat kelompok lain. Jadi peserta didik selalu berusaha lebih aktif, berfikir secara cermat dan sistematis. Pada saat peserta didik menyusun soal secara berpasangan maupun kelompok interaksi antar peserta didik terjadi, disini dua orang peserta didik saling melengkapi untuk mendapatkan soal yang benar. Demikian pula saat menjawab soal, interaksi terjadi selain antar peserta didik dalam satu kelompok juga antar kelompok.

Dari hasil angket yang diberikan peserta didik akhir siklus 1, yang menjawab bekerja secara berkelompok sangat membantu dalam memahami pelajaran $94,3 \%$, senang dengan jenis tugas yang diberikan guru $42,9 \%$, model pemberian tugas dapat membantu dalam memahami konsep pelajaran $77,1 \%$, membuat soal lagi dan menyelesaikannya semakin paham dalam memahami konsep pelajaran $65,7 \%$, tenggang waktu yang diberikan dalam menyelesaikan tugas sudak cukup 34,3\%, kegiatan yang dilakukan menambah nilai lebih dalam memahami konsep pelajaran $88,6 \%$, merasa senang dengan model pembelajaran yang baru dilakukan $82,9 \%$. Dari hasil angket ke 2 yang diberikan pada akhir siklus 2 terjadi peningkatan yang siknifikan khususnya pada pernyataan senang dengan jenis tugas yang diberikan oleh guru pada siklus 1: $42,9 \%$ dan siklus 2: $85,7 \%$ terjadi kenaikan $42,8 \%$. Membuat soal lagi dan menyelesaikannya semakin paham dalam memahami konsep pelajaran pada siklus 1: $65,7 \%$ dan pada siklus 2: $74,3 \%$ terjadi kenaikan $8,6 \%$ walapun sisanya masih belum menambah pemahaman konsep pelajaran, tenggang waktu yang diberikan dalam menyelesaikan tugas sudah cukup pada siklus 1: $34,3 \%$ dan pada siklus 2: 82,9\% terjadi kenaikan 48,6\%. Hal ini disebabkan peserta didik semakin memahami perintah yang diberikan oleh guru dan bekerja secara berpasangan sehingga dalam mengerjakan tugas lebih cepat selesai.

Keaktifan belajar peserta didik semakin meningkat ditandai oleh adanya interaksi saat pembelajaran berlangsung. Hal ini menunjukkan bahwa peserta didik tidak tergantung kepada guru, justru dapat berinteraksi antara peserta didik yang satu dengan yang lain, baik dengan teman kelompok maupun antar kelompok. Adanya suatu perubahan yang menggembirakan dalam perilaku peserta didik menghadapi pelajaran.

Dari hasil tes antara siklus 1 dan siklus 2, dapat dilihat pada tabel 3.

Tabel 3: Hasil tes siklus 1 dan siklus 2

\begin{tabular}{ccc}
\hline Kriteria nilai & Siklus 1 & Siklus 2 \\
\hline$\geq 67$ & 17 & 7 \\
$\geq 67$ & 18 & 27 \\
Jumlah & 35 & 34 \\
Rata-rata & 62,29 & 71,76 \\
\hline Prosentase ketuntasan & $48,6 \%$ & $79,4 \%$ \\
\hline
\end{tabular}




\begin{tabular}{ccc}
\hline Kriteria nilai & Siklus 1 & Siklus 2 \\
\hline$<67$ & 17 & 7 \\
$\geq 67$ & 18 & 27 \\
Jumlah & 35 & 34 \\
Rata-rata & 62,29 & 71,76 \\
\hline Prosentase ketuntasan & $48,6 \%$ & $79,4 \%$ \\
\hline
\end{tabular}

Berdasakan table 3, tampak adanya penurunan peserta didik yang mendapat nilai $<67$ dari 17 peserta didik menjadi 7 peserta didik, mengalami peningkatan peserta didik yang mendapat nilai ${ }^{3} 67$ dari 18 menjadi 27 peserta didik, dan rata-rata tes peserta didik dari 62,29 menjadi 71,76 mengalami kenaikan 2,47\%, serta prosentase ketuntasan juga mengalami peningkatan dari $48,6 \%$ menjadi $79,4 \%$ meningkat $30,8 \%$.

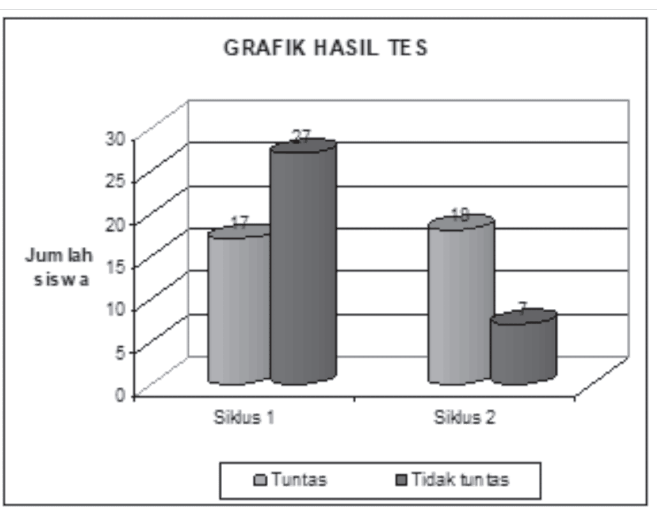

Hal ini menunjukkan bahwa dengan pendekatan model problem posing dapat meningkatkan hasil belajar peserta didik khususnya pada materi bilangan berpangkat, hal ini dapat dilihat dari hasil kerja peserta didik secara individu pada siklus 1 dan siklus 2, terjadi peningkatan prosentase ketuntasan belajar dari $48,6 \%$ menjadi $79,4 \%$ meningkat $30,8 \%$.

\section{SIMPULAN}

Berdasarkan hasil penelitian dan pembahasan yang telah dilaksanakan peneliti, maka dapat disimpulkan:

Pendekatan problem posing pada pembelajaran matematika dapat meningkatkan hasil belajar peserta didik dan melatih cara berfikir kritis peserta didik yang lebih sistematis khususnya kompetensi bilangan berpangkat. Pembelajaran dengan model problem posing sebaiknya dilakukan dalam berkelompok, yang dilakukan secara berpasangan terlebih dahulu sebelum bekerja dalam kelompok.

Peningkatan hasil belajar peserta didik tersebut dibuktikan dengan meningkatnya perolehan nilai rata-rata ulangan harian yaitu pada siklus I rata-rata tes peserta didik 62,29 dan siklus 2 rata-rata tes 71,76 mengalami kenaikan $2,47 \%$, serta prosentase ketuntasan juga mengalami peningkatan dari 48,6\% menjadi 79,4\% meningkat $30,8 \%$.

\section{DAFTAR PUSTAKA}

BSNP, 2006. Mata Pelajaran Matematika SMP. Direktorat Pembinaan SMP Ditjen Mendikdasmen Depdiknas. Jakarta: Depdiknas

Bobrow J., 2004. Matematika Dasar dan Pra-Aljabar. Pakar Raya. Bandung 
Echols M. J. dan Shadily H.,1995. Kamus Inggris Indonesia. Jakarta. PT Gramedia.

Hudoyo, H., 1990. Strategi Mengajar Belajar Matematika. Malang: IKIP Malang.

Huda, M., 2013. Model-model Pengajaran dan Pembelajaran. Yogyakarta: Pustaka Pelajar

Slameto, 2003. Belajar dan FaktorFaktor Yang Mempengaruhinya. Jakarta. Rineka Cipta.

Suryadi D., 2009. Ilmu dan Aplikasi Pendidikan Matematika.Jakarta. Imperial Bhakti Utama. FIP- UPI

Sudjana N., 1991. Teori-Teori Belajar Untuk Pengajaran. Jakarta. Fakultas Ekonomi Universitas Indonesia.

Sterling J. M., 2005. Aljabar for Dummies. Pakar Raya. Bandung

Surtini S., 2003. ImplementasiProblem Posing dan Pembelajaran Operasi Hitung Bilangan Cacah Peserta didik Kelas IV SD di Salatiga. Lembaga Penelitan Universitas terbuka. Semarang 


\title{
PENINGKATAN MOTIVASI DAN HASIL BELAJAR IPA MELALUI MODEL PEMBELAJARAN THINK PAIR SHARE DENGAN PEMBERIAN GUIDED QUESTIONS SYSTEM PADA SISWA KELAS VIII C SMP NEGERI 24 MALANG
}

\author{
Yuliati \\ SMP Negeri 24 Malang \\ Email : yuliatii2808@gmail.com
}

\begin{abstract}
Abstrak
Tujuan penelitian ini adalah untuk mendeskripsikan penerapan model pembelajaran Think Pair Share (TPS) dengan pemberian Guided Questions System (GQS) dalam meningkatkan motivasi dan hasil belajar siswa. Jenis penelitian ini adalah penelitian tindakan kelas, yang menggunakan pendekatan kualitatif dengan jumlah sampel 38 siswa. Secara umum penelitian ini dapat dibedakan dalam 2 tahap, yaitu kegiatan pendahuluan / kegiatan pra penelitian dan pelaksanaan tindakan. Penelitian ini terdiri dari dua siklus, setiap siklusnya mempunyai empat fase, yaitu 1) rencana tindakan (plan), 2) pelaksanaan (action), 3) observasi (observe), 4) refleksi (reflect). Pengumpulan data untuk mengetahui motivasi belajar siswa adalah melalui observasi (pengamatan), angket, dan catatan lapangan. Sedangkan alat pengumpulan data untuk mengetahui hasil belajar siswa dalam penelitian ini menggunakan instrumen: tes/ulangan harian dan lembar pengamatan. Selanjutnya data yang terkumpul dianalisis dengan menggunakan metode analisis data kualitatif. Adapun metode analisis data meliputi: mereduksi data, penyajian data, penarikan kesimpulan. Hasil penelitian menunjukkan bahwa pada siklus I siswa yang tuntas belajar mencapai $74 \%$, dan mengalami peningkatan sebesar $15 \%$ pada siklus ke dua sehingga menjadi $89 \%$. Sedangkan motivasi belajar juga mengalami peningkatan dari $75 \%$ menjadi $85 \%$. Sehingga dapat disimpulkan bahwa penerapan model pembelajaran TPS melalui metode $G Q S$ terbukti secara signifikan dapat meningkatkan motivasi dan hasil belajar siswa.
\end{abstract}

Kata kunci: Think Pair Share, Guided Question System, Motivasi dan Hasil Belajar

\begin{abstract}
The purpose of this research is to describe the application of Think Pair Share (TPS) learning model with the provision of Guided Questions System (GQS) in improving students' motivation and learning outcomes. This type of research is a classroom action research, which uses a qualitative approach with a sample size of 38 students. In general, this research can be distinguished in 2 stages, ie preliminary activities / pre-research activities and action implementation. This study consists of two cycles, each cycle has four phases, namely 1) plan of action (plan), 2) implementation (action), 3) observation (observe), 4) reflection. Data collection to determine student's learning motivation is through observation (observation), questionnaire, and field notes. While the data collection tool to find out student learning outcomes in this study using the instrument: daily test / test and observation sheet. Furthermore, the collected data were analyzed using qualitative data analysis method. The method of data analysis include: data reduction, data presentation, drawing conclusions. The results showed that in the first cycle students who complete learning reached $74 \%$, and increased by $15 \%$ in the second cycle to $89 \%$. While the learning motivation also increased from $75 \%$ to $85 \%$. So it can be concluded that the application of TPS learning model through GQS method proved to significantly improve motivation and student learning outcomes.
\end{abstract}

Keywords: Think Pair Share, Guided Question System, Motivation and Learning Outcomes 


\section{PENDAHULUAN}

Perkembangan masyarakat yang semakin kompleks memerlukan sumber daya manusia yang berkualitas. Berbagai pembaharuan telah dilakukan pemerintah Indonesia, terutama untuk meningkatkan mutu pendidikan nasional. Hal ini mutlak dilakukan karena pendidikan berperan penting dalam meningkatkan kualitas sumber daya manusia Indonesia. Peningkatan mutu pembelajaran IPA menjadi salah satu sasaran dalam pembangunan pendidikan nasional, karena itu dilakukan segala usaha untuk meningkatkan mutu pendidikan dan hasil belajar IPA.

Proses pembelajaran merupakan suatu proses yang mengandung serangkaian pelaksanaan oleh guru dan peserta didik atas dasar hubungan timbal-balik yang berlangsung dalam situasi edukatif untuk mencapai tujuan tertentu. Interaksi atau hubungan timbal balik antara guru dan peserta didik ini merupakan syarat utama bagi berlangsungnya proses pembelajaran.

Pada kenyataannya seringkali guru terlalu aktif di dalam proses pembelajaran, sementara peserta didik dibuat pasif, sehingga interaksi antara guru dengan peserta didik dalam proses pembelajaran tidak efektif. Jika proses pembelajaran lebih didominasi oleh guru, maka efektifitas pembelajaran tidak akan dapat dicapai. Untuk menciptakan kondisi pembelajaran yang efektif, guru dituntut agar mampu mengelola proses pembelajaran yang memberikan rangsangan kepada peserta didik agar memiliki kemauan dan kemampuan dalam mengikuti pembelajaran. Motivasi merupakan daya penggerak yang menyebabkan seseorang melakukan sesuatu perbuatan dengan cara tertentu (Moeslichatoen, 1992:2). Oleh karena itu, motivasi belajar sangat diperlukan untuk menentukan keberhasilan seseorang dalam belajar karena semakin tinggi motivasi belajar seseorang, maka semakin tinggi pula tingkat keberhasilannya. Sedangkan Mc.Donald (dalam Oemar Hamalik, 2001: 158) motivasi adalah perubahan energi dalam diri (pribadi) seseorang yang ditandai dengan timbulnya perasaan dan reaksi untuk mencapai tujuan. Benyamin S. Bloom dalam Moedjiono (1996) menyatakan bahwa belajar bertujuan untuk memperoleh perubahan tingkah laku yang meliputi ranah kognitif (pengetahuan), afektif (sikap) dan psikomotorik (ketrampilan)

Ada beberapa cara yang bisa memudahkan pemahaman yang baik dan akurat, diantaranya adalah dengan cara merangkum intisari dari materi yang disampaikan oleh guru, dengan merangkum poin inti-inti dari materi akan dapat mengembangkan pola pikir dan keterampilan bagi anak (Solehudin, 2004:34). Selain cara merangkum intisari dari materi yang akan disampaikan oleh guru sebelum proses pembelajaran, guru dapat memadukan model-model pembelajaran untuk memotivasi siswa dalam proses pembelajaran.

Dalam strategi pembelajaran terdapat model-model pembelajaran yang dapat diterapkan dalam proses pembelajaran, diantaranya model pembelajaran Think Pair Share (TPS) yaitu salah satu model pembelajaran yang memiliki prosedur yang ditetapkan secara eksplisit untuk memberi peserta didik waktu lebih banyak, menjawab, dan saling membantu satu sama lain. Pada model pembelajaran TPS terjadi proses 1) thinking (berpikir), guru mengajukan pertanyaan atau isu yang berhubungan dengan pelajaran, kemudian siswa diminta memikirkan pertanyaan atas isu yang dilontarkan secara mandiri, 
2) pairing (berpasangan), guru meminta siswa berpasangan dengan siswa lain untuk mendiskusiakan apa yang telah dipikirkan pada tahap pertama (berpikir mandiri), dan 3) sharing (berbagi), pada tahap ini guru meminta siswa perwakilan kelompok berpasangan untuk berbagi dengan seluruh kelas tentang apa yang telah didiskusikan dengan pasangannya (Chotimah, 2006). Pada kegiatan pembelajaran dengan strategi TPS tampak peserta didik menuju pemenuhan sendiri kebutuhan intelektualnya dan mengembangkannya sebagai individu berpotensi karena dalam proses pembelajaran lebih melibatkan peserta didik sebagai pemikir dari pada pengumpul pengetahuan.

Berdasarkan Observasi yang dilakukan di kelas VIII C SMP Negeri 24 Malang, IPA dianggap sebagai pelajaran yang sulit oleh sebagian besar siswa, karena memiliki banyak konsep yang menuntut pemahaman, sedangkan kemampuan siswa dalam memahami materi berbeda - beda, sehingga hasil belajar siswa-siswi kelas VIII C pada materi sebelumnya $35 \%$ siswa nilainya di bawah KKM. Penyebab rendah hasil belajar tersebut adalah siswa malas dan kurang termotivasi untuk belajar IPA, sedangkan dalam kegiatan belajar mengajar motivasi memiliki peranan yang sangat penting.

Berdasarkan uraian di atas, solusi yang bisa digunakan untuk menyelesaikan permasalahan tersebut adalah dengan melakukan suatu tindakan yang dapat memotivasi belajar sekaligus dapat meningkatkan hasil belajar siswa dalam pelajaran IPA. Untuk itulah penulis tertarik melakukan penelitian tindakan pembelajaran tentang penerapan model pembelajaran Think Pair Share (TPS) dengan pemberian Guided Questions System (GQS) untuk meningkatkan motivasi dan hasil belajar IPA siswa kelas VIII C SMP Negeri 24 Malang. Guided Questions System (GQS) adalah suatu tehnik pemberian pertanyaan-pertanyaan terstruktur yang harus dijawab dahulu oleh siswa dalam rangka memperoleh pengetahuan awal dan wawasan pada materi yang akan dibahas.

Penerapan model pembelajaran Think Pair Share (TPS) dengan pemberian Guided Questions System (GQS) ini mempunyai langkah-langkah pembelajaran sebagai berikut: (1)Siswa diminta merangkum materi secara singkat, (2) Guru mengajukan pertanyaan atau isu yang berhubungan dengan pelajaran, kemudian siswa diminta memikirkan pertanyaan atas isu yang dilontarkan secara mandiri (Think), (3) Guru meminta siswa berpasangan dengan siswa lain untuk mendiskusikan apa yang telah dipikirkan pada tahap pertama (Pair), dan (4) Guru meminta siswa perwakilan kelompok berpasangan untuk berbagi dengan seluruh kelas tentang apa yang telah didiskusikan dengan pasangannya.

Indikator keberhasilan tindakan dapat dilihat dari adanya peningkatan hasil belajar siswa yang ditandai dengan berkurangnya jumlah siswa yang mendapatkan nilai di bawah Kriteria Ketuntasan Minimum (KKM) pada saat diberikan tes/ulangan harian dari setiap siklus dan nilai kinerja siswa, yang meliputi: diskusi kelompok, diskusi kelas dan presentasi lisan. Sedangkan indikator peningkatan motivasi belajar siswa dapat dilihat dari adanya kemauan dari diri siswa untuk berpikir secara mandiri, bekerjasama dengan baik dengan pasangan dan keaktifan dalam diskusi kelas. 


\section{METODE}

Jenis penelitian ini merupakan penelitian tindakan kelas dimana dalam PTK terdapat tindakan-tindakan yang bertujuan untuk perbaikan kegiatan pembelajaran maupun peningkatan mutu pembelajaran di kelas. Pendekatan penelitian yang digunakan dalam penelitian ini adalah pendekatan kualitatif. Pendekatan kualitatif dipilih karena peneliti berupaya untuk mengkaji lebih dalam tentang peningkatan motivasi dan hasil belajar IPA siswa kelas VIII C SMP Negeri 24 Malang dengan penerapan model pembelajaran kooperatif tipe TPS.

Penelitian ini dilakukan terhadap siswa kelas VIII C SMP Negeri 24 Malang dengan jumlah siswa 38 yang terdiri dari 21 siswa perempuan dan 17 siswa lakilaki. Kondisi siswa kelas VIII C adalah heterogen, baik dari segi kemampuan akademis maupun non akademis.

Tehnik pengumpulan data untuk mengetahui motivasi belajar siswa adalah melalui observasi (pengamatan), catatan lapangan dan angket. Angket di susun dengan menggunakan skala Likert yang terdiri dari sangat setuju (SS), setuju (S), ragu-ragu (RR), tidak setuju (TS), dan sangat tidak setuju (STS) (Sudjana, 2001 dalam Chotimah, 2006). Sedangkan alat pengumpulan data untuk mengetahui hasil belajar siswa dalam penelitian ini menggunakan instrumen: tes/ulangan harian, dan lembar pengamatan. Tes yang digunakan terdiri dari 10 soal pilihan ganda, sedangkan lembar kinerja siswa berupa format penilaian proses melalui kegiatan aktivitas siswa selama pembelajaran berlangsung yang dilakukan oleh observer. Adapun validitas instrumen dilakukan dengan pengujian guru sejawat.

Sesuai dengan pendekatan yang digunakan dalam penelitian ini yaitu pendekatan kualitatif, maka data yang terkumpul dianalisis dengan menggunakan metode analisis data kualitatif. Adapun metode analisis data meliputi: mereduksi data, penyajian data, penarikan kesimpulan.

Secara umum penelitian ini dapat dibedakan dalam 2 tahap, yaitu kegiatan pendahuluan / kegiatan pra penelitian dan pelaksanaan tindakan atau penelitian. Pada tahap pra penelitian ini guru menyampaikan strategi pembelajaran model TPS, semua aktivitas saat pembelajaran akan diamati dan dinilai, serta memberitahu siswa bahwa masing-masing siswa akan dilibatkan dalam proses penilaian diri dalam kegiatan pembelajaran. Sedangkan pada tahap tindakan, setiap siklusnya mempunyai empat fase, yaitu 1) rencana tindakan (plan), 2) pelaksanaan (action), 3) observasi (observe), 4) refleksi (reflect). Model semacam ini mengikuti model yang dikembangkan oleh Kemmis dan Mc. Taggart (1998) dalam Chotimah (2006).

Adapun langkah-langkah tahap pra penelitian dan tahap tindakan adalah sebagai berikut:

1. Tahap pra-penelitian ini yang dilakukan adalah menyampaikan kepada siswa:

a. Tentang strategi pembelajaran model TPS

TPS yaitu salah satu model pembelajaran yang memiliki prosedur yang ditetapkan secara eksplisit untuk memberi kesempatan kepada peserta didik waktu lebih banyak, menjawab, dan saling membantu satu sama lain. Pada model pembelajaran TPS terjadi proses 1) thinking (berpikir), guru mengajukan pertanyaan atau isu yang berhubungan dengan pelajaran, kemudian peserta didik diminta untuk memikirkan pertanyaan atau isu yang 
telah dilontarkan secara mandiri untuk beberapa saat, 2) pairing (berpasangan), guru meminta peserta didik berpasangan dengan peserta didik yang lain untuk mendiskusikan apa yang telah dipikirkannya pada tahap pertama, dan 3) sharing (berbagi), pada tahap akhir ini guru meminta kepada pasangan untuk berbagi dengan seluruh tentang apa yang telah didiskusikan. Pada kegiatan pembelajaran dengan strategi TPS tampak peserta didik menuju pemenuhan sendiri kebutuhan intelektualnya dan mengembangkannya sebagai individu berpotensi karena dalam proses pembelajaran lebih melibatkan peserta didik sebagai pemikir dari pada pengumpul pengetahuan (Chotimah, 2007).

b. Semua aktivitas saat pembelajaran akan diamati dan dinilai

c. Masing-masing siswa akan dilibatkan dalam proses penilaian diri dalam kegiatan pembelajaran.

\section{Tahap Tindakan}

Pelaksanaan tindakan dalam penelitian ini dilakukan sesuai dengan jenis penelitian yang dipilih yaitu penelitian tindakan dengan pendekatan kualitatif. Kegiatan penelitian ini akan melalui dua putaran (siklus). Setiap siklus terdiri dari empat fase, yaitu 1) rencana tindakan (plan), 2) pelaksanaan (action), 3) observasi (observe), 4) refleksi (reflect). Model semacam ini mengikuti model yang dikembangkan oleh Kemmis dan Mc. Taggart (1998) dalam Chotimah (2006).

Adapun kegiatan-kegiatan dalam siklus dan fase tersebut adalah sebagai berikut:

a. Siklus I

1) Tahap Perencanaan

Pada siklus I ini rencana yang dibuat adalah: a) menyusun rencana pembelajaran siklus 1 disesuaikan dengan silabus, b) menempatkan siswa dalam klasikal kemudian berkelompok sesuai dengan pembagian kelompok pilihan siswa, c) menyiapkan bahan ajar sebagai bahan diskusi individu maupun bahan diskusi kelompok, d) menyiapkan lembar observasi yang akan digunakan pada saat mengamati proses pembelajaran.

2) Tahap Pelaksanaan

Pada tahap ini dilakukan kegiatan pembelajaran yang terdiri atas :

(a) Membuka pembelajaran dengan apersepsi memberi motivasi.

(b) Menjelaskan tujuan pembelajaran dan kegiatan pembelajaran yang dilakukan oleh siswa dengan menerapkan model pembelajaran TPS secara lengkap.

(c) Guru membagi siswa dalam kelompok.

(d) Guru membagikan bahan diskusi/ lembarkerja yang akan digunakan sebagai bahan ajar,yaitu "tentang percobaan sifat-sifat cahaya dan pembentukan bayangan pada cermin datar"

(e) Siswa bergabung dalam kelompok sesuai dengan pilihan siswa dan melakukan kegiatan sesuai dengan langkah-langkah pada Lembar Kerja Siswa.

(f) Siswa melakukan diskusi sesuai dengan petunjuk yang telah disampaikan oleh guru tentang model pembelajaran TPS.

(g) Guru meminta salah satu kelompok untuk menyampaikan hasil diskusi di depan kelas, sedangkan kelompok lain menanggapi.

(h) Diskusi kelas.

(i) Setelah presentasi, guru mengajak siswa untuk menyimpulkan kegiatan pembelajaran dan 
mereview materi pada saat pembelajaran dengan memberikan pertanyaan kepada siswa.

(j) Guru memberikan tugas rumah berupa pertanyaan-pertanyaan yang harus dikuasai siswa untuk pertemuan berikutnya.

(k) Guru menutup kegiatan pembelajaran dengan mengucapkan salam.

(l) Ulangan harian siklus 1

3) Tahap Observasi

(a) Melakukan observasi terhadap pelaksanaan proses pembelajaran dengan penerapan model pembelajaran TPS.

(b) Menganalisis hasil tes dan hasil lembar kerja observasi aktivitas dan keterampilan siswa dalam pembelajaran dengan model TPS.

4) Tahap Refleksi

Setelah menyelesaikan satu siklus penelitian bersama guru bidang studi yang bertugas sebagai observer melakukan diskusi untuk membahas hasil observasi terhadap pelaksanaan tindakan. Berdasarkan hasil observasi dan hasil diskusi tersebut selanjutnya dijadikan sebagai bahan refleksi dalam upaya memperbaiki tindakan pada siklus berikutnya.

b. Siklus II

1) Tahap Perencanaan

Pada siklus II ini, rencana yang dibuat adalah: a) menyusun rencana pembelajaran siklus 2, b) menempatkan siswa dalam kelompok yang telah ditetapkan oleh guru berdasarkan hasil dari refleksi siklus 1(satu kelompok terdiri dari 4-5 siswa), c) menyiapkan bahan ajar sebagai bahan diskusi individu/lembar kerja maupun bahan diskusi kelompok, d)menyiapkan lembar observasi yang akan digunakan pada saat mengamati proses pembelajaran.
2) Tahap Pelaksanaan

Pada tahap ini dilakukan kegiatan pembelajaran yang terdiri dari:

a) Membuka pembelajaran dengan apersepsi memberi motivasi.

b) Menjelaskan tujuan pembelajaran dan kegiatan pembelajaran yang dilakukan oleh siswa dengan menerapkan model pembelajaran TPS secara lengkap.

c) Guru membagi siswa dalam kelompok berdasarkan hasil refleksi dari siklus 1

d) Guru membagikan bahan diskusi yang akan digunakan sebagai bahan ajar, yaitu "tentang lensa, pembentukan bayangan pada mata dan bagian-bagian mata".

e) Siswa bergabung dalam kelompok dan melakukan kegiatan sesuai dengan langkah-langkah pada Lembar Kerja Siswa.

f) Siswa melakukan diskusi sesuai dengan petunjuk yang telah disampaikan oleh guru tentang model pembelajaran TPS.

g) Guru meminta salah satu kelompok untuk menyampaikan hasil diskusi di depan kelas, sedangkan kelompok lain menanggapi.

h) Diskusi kelas.

i) Setelah presentasi, guru mengajak siswa untuk menyimpulkan kegiatan pembelajaran dan merewiu materi pada saat pembelajaran dengan memberikan pertanyaan kepada siswa.

j) Guru menyampaikan informasi tentang materi ulangan harian.

k) Guru menutup kegiatan pembelajaran dengan mengucapkan salam.

1) Ulangan harian siklus II

3) Tahap Observasi

(a) Melakukan observasi terhadap pelaksanaan proses pembelajaran 
dengan penerapan model pembelajaran TPS.

(b) Menganalisis hasil tes dan hasil lembar kerja observasi aktivitas dan keterampilan siswa dalam pembelajaran dengan model TPS.

4) Tahap Refleksi

Pada tahap ini, peneliti dan observer melakukan refleksi mengenai proses dan hasil yang diperoleh dalam pelaksanaan tindakan pada siklus II. Refleksi meliputi analisis terhadap kelemahan dan kelebihan yang terjadi selama proses pelaksanaan tindakan pembelajaran siklus II.

\section{HASIL DAN PEMBAHASAN}

Siklus pertama terdiri atas dua pertemuan dengan materi sifat-sifat cahaya. Langkah-langkah dalam tahap perencanaan meliputi: (1)menyiapkan perangkat pembelajaran berupa Rencana Pelaksanaan Pembelajaran (RPP) dan Lembar Kerja Siswa (LKS); (2) menyiapkan alat dan bahan untuk eksperimen, (3) menyusun lembar pedoman penilaian pelaksanaan pembelajaran; (4) menyusun pedoman penilaian motivasi belajar siswa; (5) menyusun kisi-kisi tes; dan (6) menyampaikan materi yang akan dipelajari dan harus dibuat rangkuman materinya oleh siswa.

Tahap tindakan pada siklus pertama. materi yang dibahas adalah sifat-sifat cahaya pada pertemuan pertama, dan cermin datar serta sinar-sinar istimewa pada cermin lengkung untuk pertemuan kedua. Pada setiap pertemuan, guru membuka pertemuan dengan salam dan doa. Setelah pemberian apersepsi dan motivasi, guru minta siswa untuk membentuk kelompok yang teridir dari $7-8$ orang dan membagikan bahan diskusi siswa yang memuat tentang praktikum sifat-sifat cahaya maupun cermin datar dan sinar- sinar istimewa, setiap siswa mendapatkan bahan tersebut lengkap dengan lembar kerja siswa (LKS) yang diisediakan oleh guru. Setelah melakukan kegiatan praktikum secara kelompok, siswa melakukan kegiatan berpikir mandiri (Think) yang diberikan waktu 5 menit, kemudian berpikir secara berpasangan (Pair) diberikan waktu 5 menit, dan berpikir bersama kelompok (Share) diberikan waktu 5 menit. Setelah selesai mengerjakan semua bahan diskusi siswa diminta untuk mempersiapkan diri mempresentasikan hasil diskusi kelompok. Pada setiap akhir pertemuan, guru memberikan tugas pada setiap siswa untuk membuat ringkasan materi yang akan diberikan pada pertemuan berikutnya.

Pada pertemuan ketiga merupakan tahap evaluasi, guru menyiapkan soal tes siklus I yang akan diujikan ke siswa, dengan tujuan mengetahui hasil belajar siswa ketika proses pembelajaran berlangsung. Tes siklus I terdiri dari 10 soal pilihan ganda, materi yang diujikan tentang sifat-sifat cahaya, cermin datar, cermin cekung dan cermin cembung. Pada pelaksanaan tes siklus I siswa duduk secara klasikal di bangku belajarnya masing-masing, tidak dalam bentuk kelompok. Kemudian guru membagikan soal tes siklus I kepada siswa dan diberikan waktu untuk mengerjakan 20 menit. Setelah siswa menyelesaikan tes siklus I soal dikumpulkan dan dikoreksi oleh guru.

Berdasarkan hasil tes siklus I diperoleh data 28 siswa mendapat nilai minimal 70 dengan persentase $74 \%$ siswa dikatakan tuntas. Sedangkan siswa yang mendapat nilai di bawah 70 sebanyak 10 siswa dengan persentase $26 \%$. Hal ini berarti hasil belajar dikatakan belum tuntas, karena hasil belajar dikatakan tuntas secara klasikal apabila $85 \%$ siswa nilainya dalam kategori tuntas. Berdasarkan penilaian pengamat, 
diperoleh data bahwa motivasi belajar siswa mencapai $74,3 \%$, sedangkan hasil angket yang diberikan pada siswa diperoleh data bahwa motivasi belajar siswa pada siklus I 20\% sangat termotivasi, $55 \%$ termotivasi, dan $25 \%$ tidak termotivasi. Hal ini dapat dikatakan bahwa $75 \%$ siswa telah termotivasi dengan baik.

Hasil refleksi berdasarkan pengamatan pada pelaksanaan pembelajaran menunjukkan bahwa RPP yang dibuat sudah dilaksanakan dengan baik. Selain itu ditemukan fakta bahwa siswa yang pintar cenderung bergabung atau membentuk kelompok dengan teman yang mampu secara akademis. Hal ini menyebabkan adanya ketimpangan hasil belajar secara klasikal. Siswa yang anggota kelompoknya mampu secara akademis mempunyai nilai tinggi, sedangkan kelompok yang anggotanya relatif kurang mampu secara akademis hanya mendapatkan nilai yang rendah.

Adanya kelemahan-kelemahan tersebut dijadikan sebagai dasar perbaikan pada siklus II, sedangkan temuan-temuan yang sudah baik tetap dilaksanakan dan ditingkatkan sehingga diharapkan pada siklus II hasil belajar dan motivasi belajar siswa akan lebih baik.

Siklus II dilaksanakan dengan model pembelajaran yang sama dengan siklus I, yaitu menggunakan Think Pair Share dengan pemberian metode Guided Questions System. Akan tetapi ada perubahan berdasarkan hasil refleksi pada siklus I. Selain menyusun RPP untuk tiga kali pertemuan, pembentukan anggota kelompok ditentukan oleh guru dengan pertimbangan setiap kelompok mempunyai anggota yang heterogen, dan setiap kelompok terdiri dari $4-5$ siswa.

Setelah pembagian kelompok selesai, kegiatan pembelajaran ini dibuka oleh guru dengan mengingatkan kembali materi terdahulu dengan cara memberikan pertanyaan tentang unsur-unsur yang terdapat pada cermin lengkung. Guru memberikan motivasi dengan menunjukkan sebuah lup kepada siswa kemudian secara bergantian peserta didik memegang lup dan merabanya. Peserta didik juga diminta untuk menggunakan lup tersebut untuk melihat benda-benda kecil yang ada di sekitarnya. Guru bertanya " Pada saat menggunakan lup untuk melihat benda apa yang terjadi dengan benda tersebut? Dapatkah kalian menggunakan lup untuk bercermin? Guru menjelaskan bahwa lup adalah salah satu contoh lensa cembung. Lensa cembung dapat digunakan untuk memperbesar benda tetapi tidak dapat digunakan untuk bercermin, hal ini disebabkan lensa tidak dapat memantulkan cahaya tetapi lensa membiaskan cahaya yang ditangkapnya. Pada pertemuan kali ini kita akan membahas lebih lanjut tentang sinar-sinar istimewa pada lensa cembung dan lensa cekung serta cara melukis pembentukan bayangan pada lensa cembung dan lensa cekung.

Kegiatan berikutnya guru mengingatkan apakah tugas yang harus dikerjakan di rumah sudah dikerjakan? Sekitar $75 \%$ anak sudah mengerjakan dengan sempurna dan $25 \%$ anak mengerjakan belum sempurna. Guru memberikan penjelasan dan menggaris bawahi tentang tugas sinar-sinar istimewa pada cermin lengkung kemudian menanyakan pada siswa kesulitan yang dihadapi. Dari tugas yang dikerjakan di rumah dan penjelasan yang disampaikan guru melalui LCD siswa lebih mudah memahami.

Guru membagikan LKS kepada setiap siswa pada masing-masing kelompok. Untuk kegiatan melukis soal bayangan 
yang disampaikan guru dikerjakan secara mandiri (Think) dengan waktu 5 menit, kemudian bekerja secara berpasangan (Pair) diberikan waktu 5 menit dan yang terakhir bekerja secara bersama kelompok (Share) diberikan waktu 5 menit. Kegiatan berlangsung lebih tertib. Selesai kegiatan diskusi kelompok guru menunjuk satu kelompok untuk mempresentasikan hasil diskusi tentang melukis bayangan pada lensa cembung, dan satu kelompok lain mempresentasikan melukis bayangan pada lensa cekung, sedangkan kelompok lain bertanya dan menanggapi.

Kegiatan diskusi kelas berlangsung dengan lebih tertib dan siswa antusias mengikuti kegiatan diskusi. Guru bersama siswa menyimpulkan kegiatan tentang sifatsifat bayangan pada lensa cembung dan lensa cekung, guru meminta siswa untuk mencacat simpulan yang sudah dibuat di bukunya masing-masing. Karena waktu sudah usai masing-masing kelompok mengumpulkan hasil pekerjaan masingmasing anggotanya. Sebelum menutup kegiatan pembelajaran guru memberikan tugas tentang pembentukan bayangan pada mata dan menutup kegiatan pembelajaran dengan memberikan salam. Pada pertemuan kedua dan ketiga pada siklus II, pada dasarnya setiap siswa sudah dapat mengikuti pembelajaran dengan baik.

Siklus II diakhiri dengan adanya evaluasi. Hasil tes menunjukkan $89 \%$ atau 34 siswa telah tuntas belajar dan hanya $11 \%$ atau 4 siswa yang belum tuntas.

Hal ini menunjukkan adanya peningkatan banyaknya siswa yang tuntas belajar setelah diterapkannya model pembelajaran Think Pair Share menggunakan metode Guided Questions System.

Hasil belajar yang meningkat ini juga seiring dengan meningkatnya motivasi belajar siswa. Hal ini ditunjukkan dengan hasil pengamatan dan angket yang telah diisi siswa. Hasil penilaian pengamat menunjukkan bahwa motivasi belajar siswa mencapai $78 \%$, sedangkan berdasarkan angket diperoleh data bahwa motivasi belajar siswa pada siklus II $28 \%$ sangat termotivasi, $63 \%$ termotivasi, dan $9 \%$ tidak termotivasi. Hal ini dapat dikatakan bahwa $91 \%$ siswa telah termotivasi dengan baik karena penerapan model pembelajaran Think Pair Share menggunakan metode Guided Questions System.

Berdasarkan uraian mengenai motivasi belajar siswa kelas VIII C SMP Negeri 24 Malang selama siklus I dan siklus II dapat dilihat perolehan prosentase rata-rata motivasi belajar siswa dalam Tabel 1 .

Tabel 1: Motivasi Belajar Siswa

\begin{tabular}{cccc}
\hline & \multicolumn{3}{c}{ Penilaian Motivasi } \\
\cline { 2 - 4 } & Angket & Pengamatan & Rata-rata \\
\hline Siklus I & 75 & 74,3 & 75 \\
\hline Siklus II & 91 & 78 & 85 \\
\hline
\end{tabular}

Peningkatan hasil belajar dan motivasi belajar dalam penelitian ini dapat ditunjukkan dalam tabel 2. berikut:

Tabel 2: Hasil belajar dan motivasi belajar siklus I dan siklus II

\begin{tabular}{ccc}
\hline Siklus & Hasil Belajar (\%) & Motivasi (\%) \\
\hline I & 74 & 75 \\
\hline II & 89 & 85 \\
\hline
\end{tabular}

Adapun grafiknya dapat ditunjukkan pada gambar 1 . 


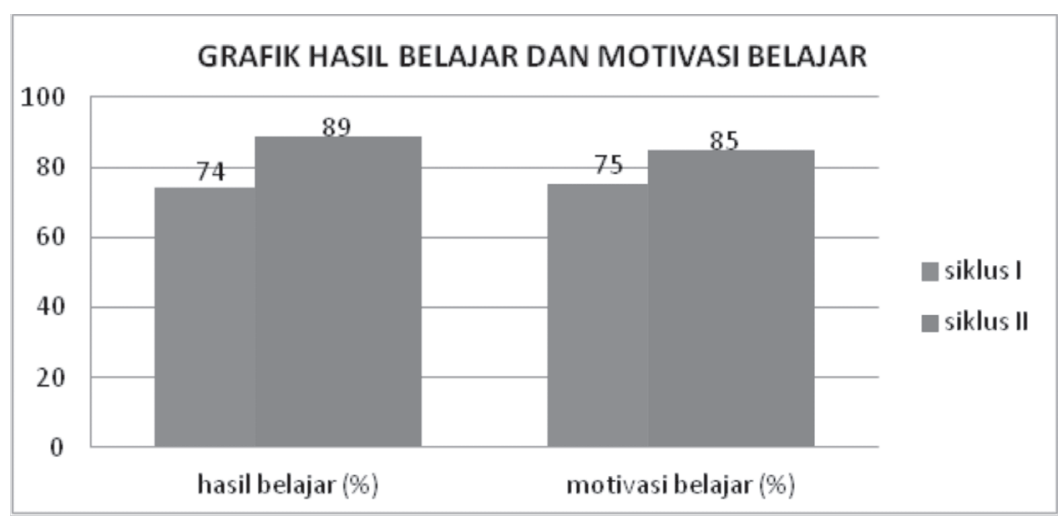

Gambar 1. Grafik Hasil Belajar dan Motivasi Belajar Siklus I dan Siklus II

Berdasarkan grafik diatas terlihat bahwa penerapan model pembelajaran TPS dengan metode pemberian tugas terstruktur (GQS) dapat meningkatkan hasil belajar konsep sifat-sifat cahaya dan cermin datar, cermin lengkung, lensa cekung, lensa cembung, proses pembentukan bayangan pada mata manusia, bagian-bagian mata, kelainan pada indera penglihatan, dan proses pembentukan bayangan pada mata serangga. Pada siklus I siswa yang tuntas belajar adalah $74 \%$ dan $26 \%$ belum tuntas belajar. Pada siklus II siswa yang tuntas belajar mencapai $89 \%$ dan $11 \%$ belum tuntas. Hal ini menunjukkan terjadinya peningkatan ketuntasan belajar secara klasikal sebesar $15 \%$ dan terjadi penurunan banyaknya siswa yang belum tuntas yakni sebesar $15 \%$. Adanya peningkatan hasil belajar ini tidak terlepas dari adanya motivasi belajar yang pada akhirnya mempengaruhi aktivitas/kinerja ilmiah yang menarik dan dapat memberi kesempatan pada siswa untuk berpikir, bertanya dan berpendapat, serta berinteraksi dengan teman sebayanya.

\section{SIMPULAN}

Penerapan model pembelajaran Think Pair Share menggunakan metode Guided Questions System dapat meningkatkan motivasi dan hasil belajar
IPA siswa kelas VIII C SMP Negeri 24 Malang.

Berdasarkan hasil penelitian maka dapat dikemukakan saran sebagai berikut: (1) penerapan model pembelajaran Think Pair Share menggunakan metode Guided Questions System dapat dijadikan alternatif dalam proses pembelajaran mata pelajaran lain; dan (2) penerapan model pembelajaran Think Pair Share menggunakan metode Guided Questions System dapat dikembangkan lebih lanjut untuk materi-materi yang lain.

\section{DAFTAR PUSTAKA}

Chotimah, Husnul. 2006. Model-model Pembelajaran untuk Penelitian Tindakan Kelas

Mulyasa, E. 2009. Penelitian Tindakan Kelas. Bandung: PT Remaja Rosdakarya

Moedjiono. 1996. Strategi Belajar Mengajar. Malang: pendidikan Akta IV IKIP MALANG

Moeslichatoen. 1992. Motivasi Dalam Proses Belajar Mengajar, Malang:Depdikbud IKIP Malang

Hamalik, Oemar. 2001. Proses Belajar Mengajar, Bandung, penerbit Bumi Aksara

Solehudin. 2004. Metode Pembelajaran, Bandung: PT Al Zahra 


\title{
PENINGKATAN MINAT KEWIRAUSAHAAN SISWA SMP DENGAN PENDEKATAN SCIENTIFIC SELL
}

\author{
Zakki Fitroni \\ SMP Muhammadiyah 8 Batu \\ Email: zakki.fitroni@gmail.com
}

\begin{abstract}
ABSTRAK
Jiwa kewirausahaan dapat ditanamkan melalui pengintegrasian pendidikan kewirausahaan kedalam pembelajaran. Dalam meningkatkan minat siswa SMP Muhammadiyah 8 Batu untuk berwirausaha diperlukan sebuah pendekatan pembelajaran yang mampu memasukkan nilai kewirausahaan secara efektif ke dalam pembelajaran. Dengan memodifikasi pendekatan scientific dan menambahkan satu langkah lagi yaitu Sell (menjual) sehingga pendekatan ini dinamakan pendekatan Scientific Sell. Keterlaksanaan pendekatan scientific sell dalam materi melukis ragam hias pada media bangkiak, mampu meningkatkan minat siswa terhadap kewirausahaan siswa dengan menggunakan langkah; Mengamati, menanya mengumpulkan informasi, mengasosiasi, mencipta, menjual dan Mengkomunikasikan/refeksi. Keberhasilan pendekatan ini dapat dilihat dari hasil penilaian psikomotor dengan rata rata nilai yang diperoleh adalah $84,32 \%$ danrata-rata nilai kognitif yang diperoleh adalah $82,19 \%$. Sedangkan Nilai afektif didapat berdasarkan pengamatan minat siswa di siklus I sebesar 85,93\%, dan mengalami peningkatan sebesar $2,55 \%$ sehingga menjadi $88,48 \%$ pada siklus II.
\end{abstract}

Kata kunci: Kewirausahaan, Minat, Scientific Sell.

\begin{abstract}
The entrepreneurial spirit can be instilled through the integration of entrepreneurship in process of teaching and learning. In increasing the interest for entrepreneurship of SMP Muhammadiyah 8 Batu students, it required a learning approach that is able to enter the value of entrepreneurship effectively to process of learning.By modyfiyng the scientific approach and adding one more step, Sell as the result of this scientific approach. The characteristic of scientific approach in the form of decorative painting from a Bengkiak, able to increase the interest of the student towards enterpreneurship. The research is conducted by using some steps: observing, asking question and getting a data, associating, creating, selling, and communicating/reflectioning. The success of this approach can be seen from the result of student average obtained score of 84.32 and the average score of the cognitive of 82.19. Meanwhile, the affective score obtained by observation of the students' interest in the first cycle is 85.93 and raising a level to 2.55 up to 88.48 in the second cycle.
\end{abstract}

Key word: Enterpreneurship, Interest, Scientific Sell.

\section{PENDAHULUAN}

Seorang wirausahawan merupakan sumber daya manusia yang memiliki kemampuan yang kreatif, inovatif, dinamis, dan proaktif terhadap tantangan yang ada di masa sekarang. Sosok wirausaha sangat dibutuhkan oleh negara, terutama menjelang era perdagangan bebas yang akan diikuti oleh Indonesia. Dengan banyaknya wirausaha, maka dua indikator penting dalam suatu negara secara ekonomi dapat terpenuhi, yaitu rendahnya angka pengangguran dan tingginya devisa terutama dari hasil barang-barang ekspor yang dihasilkan. Hal ini didukung oleh pernyataan PBB yang mengatakan bahwa: 
Suatu Negara akan mampu membangun apabila memiliki wirausahawan sebanyak $2 \%$ dari jumlah penduduknya. Jadi, jika Negara berpenduduk 200 juta jiwa, maka wirausahawannya harus lebih kurang sebanyak 4 juta. Katakanlah jika kita hitung semua wirausahawan Indonesia mulai dari pedagang kecil sampai perusahaan besar ada sebanyak 3 juta, tentu bagian terbesarnya adalah kelompok kecil-kecil yang belum terjamin mutunya dan belum terjamin kelangsungan hidupnya (kontinuitasnya) (Alma, 2009:4).

Pernyataan tersebut diperkuat oleh David Mc Clelland dalam Basrowi (2016:81) bahwa suatu negara bisa menjadi makmur jika memiliki sedikitnya $2 \%$ entrepreneur (wirausahawan) dari jumlah penduduk. Di Indonesia sendiri minat berwirausaha masih kurang. Hal tersebut sesuai dengan pernyataan Menteri Koperasi dan UKM, A.A.G.N Puspayoga dalam pembukaan acara Wirausaha Muda Mandiri 2015. Saat ini jumlah populasi wirausaha di Indonesia baru mencapai angka $0,43 \%$ dari total populasi usia produktif, angka ini sangat jauh tertinggal jika dibandingka dengan beberapa negara tetangga, sperti Singapura yang jumlah wirausahanya sudah mencapai $7 \%$, Malaysia $5 \%$, dan Thailand $3 \%$. Dan target entrepreneur di Indonesia harus bisa bertambah, minimal harus bisa mencapai $2 \%$ dari total populasi. (http:// swa.co.id)

Jika dilihat berdasarkan kriteria dari PBB dan Mc Clelland, maka jumlah wirausaha di Indonesia masih sangat jauh dari ideal, yang minimal harus dua persen untuk membangun pertumbuhan perekonomian secara optimal. Tantangan tersebut seharusnya mampu dijawab oleh para pendidik di negeri ini, dengan membantu menghasilkan calon-calon entrepreneur baru melalui kegiatan belajar mengajar yang mendukung penanaman dan pengenalan entrepreneurship.

Seni budaya sebagai salahsatu mata pelajaran yang sebagian besar materinya adalah materi praktek, tentu sangat potensial untuk dapat mengintegrasikan pendidikan entrepreneur kedalam materi-materi yang ada didalamnya. Agar pendidikan entrepreneur dapat terintegrasi dengan maksimal dan mempunyai pengaruh efektif terhadap peserta didik, maka diperlukan sebuah pendekatan pembelajaran yang tepat.

Ada beberapa pendekatan dalam pembelajaran, tetapi dalam penelitian ini yang akan diangkat adalah pendekatan saintifik, karena merupakan pendekatan yang dipakai pada Kurikulum 2013 untuk kegiatan pembelajaran, termasuk pada pelajaran seni budaya. Pendekatan saintifik mempunyai beberapa langkah yaitu mengamati, menanya, menalar, mencoba, dan membentuk jejaring. Agar pendekatan ini dapat efektif dalam mengintegrasikan pendidikan entrepreneur kedalam materi pembelajaran. Diasumsikan bahwa pendekatan ini harus dimodifikasi dengan menambahkan satu langkah lagi yaitu "menjual" (Sell) sehingga pendekatan yang akan di aplikasikan kedalam penelitian tindakan kelas ini dinamakan pendekatan Scientific Sell.

Kompetensi Dasar yang akan dipakai untuk mengaplikasikan pendekatan Scientific Sell dalam pelajaran seni budaya adalah "membuat karya kriya kayu dengan memanfaatkan berbagai teknik dan corak". Peserta didik akan melukis ragam hias pada media bangkiak dengan menggunakan cat akrilik, kemudian memasarkan bangkiak yang sudah diberi ragam hias hasil karya mereka dan terakhir mempresentasikan tentang proses berkarya 
dan proses menjual. Diharapkan dari proses tersebut akan dapat diketahui bagaimana pendekatan Scientific Sell dapat meningkatkan kewirausahaan para peserta didik

Berdasarkan latar belakang yang telah diuraikan diatas, maka rumusan masalah dalam penelitian ini meliputi bagaimana penerapan pendekatan Scientific Sell pada materi melukis ragam hias pada media bangkiak di kelas 7 SMP Muhammadiyah 8 Batu dan bagaimana hasil pendekatan Scientific Sell pada materi melukis ragam hias pada media bangkiak dalam meningkatkan minat berwirausaha siswa kelas 7 SMP Muhammadiyah 8 Batu.

\section{METODE}

Penelitian berjudul "Peningkatan Minat Kewirausahaan Siswa SMP Dengan Pendekatan Scientific Sell'ini merupakan penelitian tindakan kelas yang dilakukan dalam upaya meningkatkan minat siswa dalam hal kewirausahaan. Pendekatan yang digunakan dalam penelitian ini adalah pendekatan deskriptif. Apabila datanya telah terkumpul lalu diklasifikasikan menjadi dua kelompok data, yaitu kuantitatif yang berbentuk angka-angka dan data kualitatif yang dinyatakan dalam kata-kata atau simbol.

Pada siklus I langkah awal yang dilakukan peneliti adalah menyebarkan angket pra tindakan untuk mengetahui sejauh mana motivasi siswa untuk belajar kewirausahaan. Pembelajaran pada siklus ini, siswa melakukan proses pengamatan, menanya, mengumpulkan informasi, mengasosiasi, mencipta dan menjual. Terdapat beberapa data yang diambil yaitu nilai afektif 1 yang diambil dari lembar observasi tentang perilaku siswa dalam pembelajaran, nilai psikomotor yang diambil dari karya siswa berupa bangkiak lukis yang dihasilkan dari proses mencipta, dan angket pasca tindakan siklus 1. Dari data yang terkumpul terutama nilai afektif dan angket pasca tindakan siklus 1 menunjukkan bahwa tindakan dapat dilanjutkan pada siklus II untuk mendapatkan hasil yang maksimal dalam meningkatkan motivasi wirausaha.

Siklus II siswa melakukan langkah mengkomunikasikan dan refleksi, dengan langkah tersebut siswa diharapkan mampu menjelaskan tentang kegiatan pembelajaran dengan langkah-langkah yang sudah ditempuh pada siklus sebelumnya sehingga akan muncul diskusi dan saling bertukar pendapat diantara mereka. Pada siklus ini data yang didapat adalah nilai afektif dari lembar observasi tentang perilaku siswa, nilai kognitif yang didapat dari kemampuan siswa untuk presentasi di depan kelas, dan angket pasca tindakan siklus II.

Instrumen yang dipakai untuk mengumpulkan data pada penelitian ini adalah sebagai berikut; pertama, lembar observasi yang digunakan sebagai lembar pengamatan untuk mengukur kemandirian belajar siswa selama proses pembelajaran berlangsung. Lembar observasi ini juga digunakan sebagai bahan refleksi siklus berikutnya; kedua, pedoman wawancara digunakan untuk mengetahui tanggapan peserta didik serta ada tidaknya hambatan mengenai pembelajaran dengan pendekatan Scientific Sell; ketiga, Angket merupakan instrumen pencarian data yang berupa pertanyaan tertulis yang memerlukan jawaban tertulis. Instrumen ini disusun berdasarkan indikator yang dapat mengungkapkan minat peserta didik dalam berwirausaha. Pilihan setiap butir angket terdiri dari jawaban "ya" dan "tidak".

Data yang sudah diperoleh pada siklus I dan siklus II pendekatan Scientific Sell, 
kemudian dibandingkan. Antara nilai afektif pada siklus I dan nilai afektif 2 terdapat kenaikan, membandingkan jawaban siswa pada angket pra tindakan siklus I, pasca tindakan siklus I dan pasca tindakan siklus II adakah peningkatan. Dari perbandingan tersebut maka akan dapat disimpulkan hasil dari penelitian ini.

Pada penelitian ini yang menjadi subjek adalah siswa kelas VII 2 di SMP Muhammadiyah 8 Batu. Alasan sekolah ini dipilih. Pertama, karena peneliti adalah pendidik di sekolah ini sehingga diharapkan dapat lebih intensif dalam meneliti. Kedua, sebagai pendidik di sekolah ini tentu lebih mengetahui karakter peserta didik. Ketiga, kurangnya minat siswa terhadap kewirausahaan sehingga diperlukan sebuah inovasi pembelajaran yang dapat meningkatkan minat para peserta didik untuk berwirausaha.

\section{HASIL DAN PEMBAHASAN}

Hasil penelitian ini didasarkan pada 2 hal yaitu penilaian hasil belajar siswa menggunakan pendekatan Scientific Sell dan observasi terhadap minat siswa dalam berwirausaha. Menurut Hisrich-Peters (Alma, 2004: 26), kewirausahaan adalah proses menciptakan sesuatu yang lain dengan menggunakan waktu dan kegiatan disertai modal dan resiko serta menerima balas jasa dan kepuasan serta kebebasan pribadi. Atas definisi tersebut maka pengamatan yang dilakukan pada saat seluruh proses pembelajaran dilakukan adalah untuk mengamati efektivitas dan antusiasme atau minat belajar siswa terhadap pendekatan Scientific Sell dalam pembelajaran Seni Budaya pada Kompetensi Dasar "membuat karya kriya kayu dengan memanfaatkan berbagai teknik dan corak" khususnya pada materi melukis ragam hias pada media bangkiak.
Efektivitas pendekatan Scientific Sell dalam meningkatkan minat siswa untuk berwirausaha ini dapat dilihat dari hasil belajar siswa dan pengamatan/observasi yang dilakukan oleh guru pada saat pembelajaran dilaksanakan. Adapun paparan data hasil penelitian pada siklus I maupun siklus II dijabarkan dalam bagian-bagian setiap tahap siklus tindakan.

Pelaksanaan Tindakan dan Observasi Siklus I

Di awal pembelajaran dengan materi melukis ragam hias pada bangkiak, disebar angket pra pelaksanaan tindakan I tentang minat wirausaha kepada seluruh siswa kelas 7.2 yang berjumlah 29. Dalam angket tersebut terdapat dua pertanyaan; pertama "Apakah kamu punya cita-cita untuk berwirausaha?" 8 (27,59\%) siswa menjawab "iya" dengan alasan mengikuti jejak orang tua atau terinspirasi dari para pengusaha sukses yang mampu menghasilkan banyak uang, sedangkan sisanya $21(72,41 \%)$ siswa menjawab "tidak" karena ingin menggeluti profesi lain seperti dokter, tentara, pejabat, atau guru. pertanyaan kedua "Apakah menurutmu pendidikan tentang kewirausahaan tepat diajarkan sejak dini?" 14 (48,27\%) siswa menjawab "iya" dengan alasan karena memang diperlukan, sedangkan sisanya 15 (51,72\%) siswa menjawab "tidak" dengan alasan tidak semua siswa ingin menjadi pengusaha.

Setelah angket pra siklus I disebar, maka dimulai tahapan-tahapan pendekatan Scientific Sell pada pembelajaran:

\section{MENGAMATI}

Pada langkah mengamati, siswa melakukan pengamatan karya seni kriya ragam hias flora, fauna dan geometrik yang ditunjukkan oleh guru melalui LCD. 
Setelah itu membaca buku tentang konsep dan prosedur membuat karya flora, fauna dan geometrik daerah. Guru meminta siswa untuk keluar kelas dan mengamati lingkungan di luar kelas yang berhubungan dengan flora fauna dan geometris yang bisa dikembangkan menjadi gambar ragam hias.

\section{MENANYAKAN}

Siswa mengumpulkan hasil pengamatannya tentang ragam hias dan bangkiak yang sudah di beri ragam hias. Dari kegiatan tersebut, para siswa mengajukan beberapa pertanyaan seperti; Apakah ragam hias itu? adalah bentuk dasar hiasan yang biasanya akan menjadi pola yang diulang-ulang dalam suatu karya kerajinan atau seni. Karya ini dapat berupa tenunan, tulisan (misalnya batik), songket, ukiran, atau pahatan pada kayu/batu. Bagaimanakah cara membuat ragam hias? yaitu dengan metode ATM (Amati Tiru Modifikasi) sehingga menghasilkan ragam hias sesuai dengan motif daerah-daerah tertentu dan bisa juga dimodifikasi, Apa fungsi ragam hias? menambah keindahan atau estetika suatu benda dan juga menambah simbol atau makna sehingga mampu meningkatkan nilai benda tersebut.

\section{MENGUMPULKAN INFORMASI}

Siswa berusaha menggali dan mengumpulkan informasi tentang ragam hias bangkiak dari berbagai sumber seperti majalah, koran, video di youtube, instagram, website, pengerajin bangkiak, pelukis atau sumber-sumber lain. Sumber-sumber berupa foto, gambar, video atau catatan hasil wawancara tersebut kemudian dikumpulkan dan dipilah-pilah. Data tersebut nantinya akan dijadikan sebagai acuan untuk langkah mengasosiasi.

\section{MENGASOSIASI}

Dari data-data yang sudah dikumpulkan oleh siswa tentang ragam hias maka langkah selanjutnya adalah memproses informasi yang sudah dikumpulkan baik terbatas dari hasil kegiatan mengumpulkan/eksperimen maupun hasil dari kegiatan mengamati dan kegiatan mengumpulkan informasi sehingga terbentuk suatu persepsi baru tentang pengaplikasian ragam hias pada media bangkiak.

\section{MENCIPTA}

Setelah menemukan keterkaitan antar informasi dan menemukan berbagai pola dari keterkaitan tersebut, selanjutnya secara bersama-sama dalam satu kesatuan kelompok, atau secara individual membuat kesimpulan dengan cara menuangkannya/ mencipta menjadi sebuah karya ragam hias pada media bangkiak.

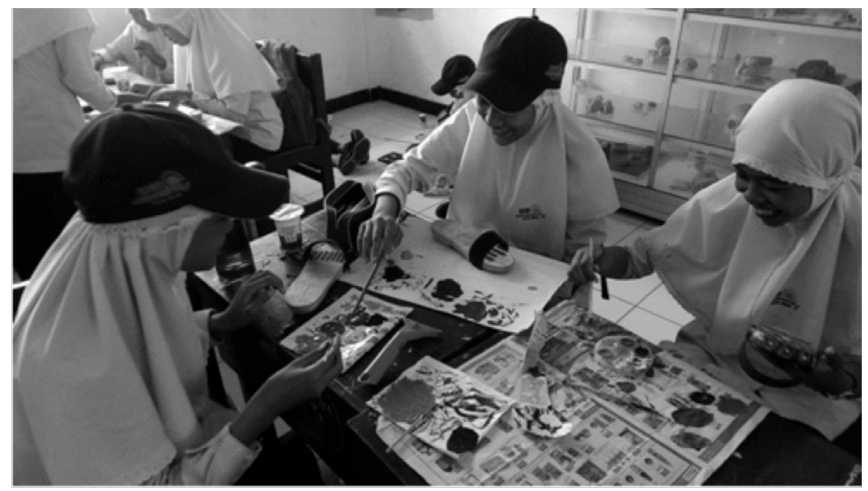

Gambar 1. Pengerjaan lukis ragam hias pada media bangkiak 
Nilai Psikomotor

Dari hasil karya bangkiak yang dihasilkan siswa kelas 7.2 pada kompetensi dasar "membuat karya kriya kayu dengan memanfaatkan berbagai teknik dan corak" khususnya pada materi melukis ragam hias pada media bangkiak, rata rata nilai yang diperoleh adalah 84,32 .

\section{MENJUAL}

Peserta didik harus berusaha menjual hasil karyanya kepada orangorang di sekitarnya dengan menghitung terlebih dahulu biaya produksi dan menentukan laba sehingga keuntungan yang diperoleh bisa lebih maksimal, dalam waktu 1 minggu.

\section{Nilai Afektif}

Berdasarkan pengamatan minat siswa pada pembelajaran melukis ragam hias dengan pendekatan Scientific Sell dapat diketahui bahwa minat siswa pada pembelajaran sebesar $85,93 \%$. Dengan indikator pengamatan kesiapan sebelum memulai pembelajaran, pengerjaan tugas rumah, perhatian selama pembelajaran berlangsung, interaksi antara peserta didik dan guru, mengemukakan pertanyaan kepada guru, kesediaan menerima tugas dan respon yang ditunjukan, terlibat aktif dalam kelompok, kerja sama dalam kelompok, kemauan untuk membaca/ mencari referensi ragam hias, dan kehadiran (dinilai di akhir penelitian).

Di akhir pembelajaran pada siklus I,disebarkan angket pasca pelaksanaan tindakan siklus I tentang minat wirausaha kepada seluruh siswa kelas 7.2 yang berjumlah 29. Dalam angket tersebut terdapat lima pertanyaan; pertama "Apakah kamu tertarik untuk berwirausaha / menjadi pengusaha?" $19(65,52 \%)$ siswa menjawab "iya" dengan alasan mengikuti jejak orang tua, terinspirasi dari para pengusaha sukses yang mampu menghasilkan banyak uang, atau dengan modal kreatifitas maka banyak hal yang dapat dijadikan sebagai peluang usaha. sedangkan sisanya $10(34,48 \%)$ siswa menjawab "tidak" karena ingin menggeluti profesi lain seperti dokter, tentara, pejabat, atau guru. pertanyaan kedua "Apakah menurutmu pendidikan tentang kewirausahaan tepat di ajarkan sejak dini?" 22 (75,86\%) siswa menjawab "iya" dengan alasan karena indonesia membutuhkan banyak wirausahawan dan harus di tanamkan sejak dini, sedangkan sisanya $7(24,14 \%)$ siswa menjawab "tidak" dengan alasan keinginan menjadi profesi lain.

Pertanyaan ketiga "Apakah kamu menyukai kegiatan pembelajaran melukis ragam hias pada bangkiak dengan menggunakan pendekatan Scientific Sell?" 25 (86,2\%) siswa menjawab "iya" dengan alasan karena pembelajaran scientific dipakai pada mata pelajaran K13 tetapi pada Scientific Sell berbeda karena kita diharuskan untuk membuat benda yang mempunyai nilai jual dan harus menjualnya, sedangkan sisanya $4(13,8 \%)$ siswa menjawab "tidak" dengan alasan hampir sama dengan pembelajaran pada umumnya; Pertanyaan keempat "Apakah kamu menyukai kegiatan menjual (Sell) dalam pendekatan Scientific Sell?" 16 $(55,17 \%)$ siswa menjawab "iya" dengan alasan seru karena tidak pernah berjualan, sedangkan sisanya $13(44,82 \%)$ siswa menjawab "tidak" dengan alasan malu; Pertanyaan kelima "Apakah menurutmu bangkiak yang sudah kamu beri ragam hias layak untuk dijual?" $20(68,96 \%)$ siswa menjawab "iya" dengan alasan membuatnya dengan susah payah dan menjasi bangkiak yang bagus, sedangkan 
sisanya $13(44,82 \%)$ siswa menjawab dan tidak seimbang antara yang kanan dan "tidak" dengan alasan jelek, tidak rapi, kiri.

\section{Refleksi Siklus I}

Tabel 1. Refleksi hasil observasi dan analisis pada siklus I

\begin{tabular}{lc}
\hline \multicolumn{1}{c}{ Keterangan } & Hasil \\
\hline Nilai rata-rata tugas siswa berkarya bangkiak lukis & 84,32 \\
\hline $\begin{array}{l}\text { Minat siswa pada pembelajaran bangkiak lukis dengan } \\
\text { pendekatan Scientific Sell }\end{array}$ & $85,93 \%$ \\
\hline $\begin{array}{l}\text { Peningkatan keinginan siswa dalam berwirausaha, dari } 8 \\
\text { anak (27,59\%) meningkat menjadi }\end{array}$ & $\begin{array}{c}19 \text { anak } \\
(65,52 \%)\end{array}$ \\
\hline $\begin{array}{l}\text { Meningkatnya kesadaran akan kebutuhan pendidikan } \\
\text { kewirausahaan sejak dini, dari 14 anak (48,27\%) } \\
\text { meningkat menjadi }\end{array}$ & $\begin{array}{c}22 \text { anak } \\
(75,86 \%)\end{array}$ \\
\hline $\begin{array}{l}\text { Siswa yang menyukai pembelajaran dengan pendekatan } \\
\text { Scientific Sell }\end{array}$ & 25 anak (86,2\%) \\
\hline $\begin{array}{l}\text { Siswa yang menyukai kegiatan/langkah menjual ( sell) } \\
\text { dalam pendekatan Scientific Sell }\end{array}$ & $\begin{array}{c}16 \text { anak } \\
(55,17 \%)\end{array}$ \\
\hline $\begin{array}{l}\text { Pendapat siswa bahwa hasil karya mereka layak jual } \\
20 \text { anak } \\
(68,96 \%)\end{array}$ \\
\hline
\end{tabular}

Pada siklus I langkah-langkah pendekatan Scientific Sell adalah mengamati, menanya, mengumpulkan informasi, mengasosiasi, mencipta dan menjual. Tetapi berdasarkan evaluasi pada siklus I langkah-langkah tersebut masih bisa dimaksimalkan untuk meningkatkan minat siswa dalam berwirausaha dengan menambah satu langkah lagi yaitu mengkomunikasikan/refleksi dari langkahlangkah sebelumnya. Sehingga pendekatan pembelajaran Scientific Sell masih perlu diperbaiki lagi dalam langkah selanjutnya agar minat siswa terhadap wirausaha dapat lebih baik lagi pada siklus II.

\section{Pelaksanaan Tindakan dan Observasi Siklus II}

Berdasarkan pelaksanaan tindakan pada siklus I dan observasi diketahui bahwa siswa lebih senangdan bersemangat dalam mengikuti pelajaran seni budayapada materi melukis ragam hias pada bangkiak dengan menggunakan pendekatan pembelajaran Scientific Sell. Hanya saja dari hasil evaluasi pada siklus I, minat wirausaha diasumsikan dapat meningkat ketika di perbaiki/modifikasi dan dilanjutkan pada siklus II. Minat usaha yang dimaksudkan dalam penelitian ini sejalan dengan definisi Subandono (2007: 18), bahwa minat wirausaha adalah kecenderungan hati dalam diri subjek untuk tertarik menciptakan suatu usaha yang kemudian mengorganisir, mengatur, menanggung risiko dan mengembangkan usaha yang diciptakannya tersebut. Minat wirausaha berasal dari dalam diri seseorang untuk menciptakan sebuah bidang usaha.

Pada siklus II pelaksanaan tindakan difokuskan pada langkah terakhir dalam pendekatan Scientific Sell yaitu Mengkomunikasikan/refeksi. Dalam langkah ini siswa diharapkan dapat mengkomunikasikan dan merefleksikan tentang apa yang telah mereka pelajari 
dan alami pada langkah-langkah sebelumnya. Kegiatan ini dilakukan dengan cara menceritakan apa yang ditemukan dalam kegiatan mengamati, menanya, mengumpulkan informasi, mengasosiasi, mencipta dan menjual. Hasil tersebut disampikan di depan kelas dan dinilai oleh guru sebagai hasil belajar siswa atau kelompok siswa tersebut.

\section{Nilai Kognitif}

Pada pelaksanaan tindakan IInilai kognitif siswa diukur melalui rubrik penilaian presentasi, sehingga diketahui bahwa ratarata nilai kognitif siswa kelas 7.2 pada pembelajaran melukis ragam hias dengan media bangkiak adalah $82,19 \%$.

\section{Nilai Afektif}

Berdasarkan pengamatan minat siswa pada pembelajaran melukis ragam hias dengan pendekatan Scientific Sell dapat diketahui bahwa minat siswa pada pembelajaran sebesar $88,48 \%$. Dengan indikator pengamatan kesiapan sebelum memulai pembelajaran, pengerjaan tugas rumah, perhatian selama pembelajaran berlangsung, interaksi antara peserta didik dan guru, mengemukakan pertanyaan kepada peserta didik yang presentasi, kesediaan menerima tugas dan respon yang ditunjukan, terlibat aktif dalam presentasi, kerja sama dalam presentasi, kemauan untuk membaca/mencari referensi ragam hias, dan kehadiran (dinilai di akhir penelitian).

Tabel 2. angket pasca pelaksanaan tindakan siklus II.

\begin{tabular}{ll}
\hline $\begin{array}{l}\text { Apakah kamu tertarik untuk berwirausaha / } \\
\text { menjadi pengusaha? }\end{array}$ & $\begin{array}{l}\text { Iya,26 }(89,65 \%) \text { siswa } \\
\text { Tidak,3 }(10,34 \%) \text { siswa }\end{array}$ \\
\hline $\begin{array}{l}\text { Apakah menurutmu pendidikan tentang } \\
\text { kewirausahaan tepat di ajarkan sejak dini? }\end{array}$ & $\begin{array}{l}\text { Iya, 26 }(89,65 \%) \text { siswa } \\
\text { Tidak, } 3(10,34 \%) \text { siswa }\end{array}$ \\
\hline $\begin{array}{l}\text { Apakah kamu menyukai kegiatan pembelajaran } \\
\text { melukis ragam hias pada bangkiak dengan } \\
\text { menggunakan pendekatan Scientific Sell? }\end{array}$ & $\begin{array}{l}\text { Iya, 27 }(93,1 \%) \text { siswa } \\
\text { Tidak, 2 }(6,89 \%) \text { siswa }\end{array}$ \\
\hline $\begin{array}{l}\text { Apakah kamu menyukai kegiatan menjual (Sell) } \\
\text { dalam pendekatan Scientific Sell? }\end{array}$ & $\begin{array}{l}\text { Iya, 23 }(79,31 \%) \text { siswa } \\
\text { Tidak, 6 }(20,69 \%) \text { siswa }\end{array}$ \\
\hline $\begin{array}{l}\text { Apakah bangkiak yang sudah kamu beri ragam } \\
\text { hias terjual? }\end{array}$ & $\begin{array}{l}\text { Iya, 24 }(68,96 \%) \text { siswa } \\
\text { Tidak, 5 }(17,24 \%) \text { siswa }\end{array}$ \\
\hline
\end{tabular}

\section{Refleksi Siklus II}

Dari hasil observasi dan analisis pada siklus II diperoleh data sebagai berikut.

Dari hasil presentasi yang dilakukan siswa kelas 7.2 pada kompetensi dasar "membuat karya kriya kayu dengan memanfaatkan berbagai teknik dan corak" khususnya tentang proses pembelajaran melukis ragam hias pada media bangkiak dan menjualnya, rata rata nilai yang diperoleh adalah $82,19 \%$.

Berdasarkan pengamatan minat siswa pada kegiatan mengkomunikasikan/ refleksi tentang proses pembelajaran melukis ragam hias pada media bangkiak dengan pendekatan Scientific Sell dapat diketahui bahwa 
minat siswa pada pembelajaran sebesar $88,48 \%$.

- Berdasarkan angket yang sudah disebar, sesudah tindakan pada siklus II dapat diketahui. Sesudah tindakan siklus II, $26(89,65 \%)$ siswa punya keinginan untuk berwirausaha. Pendapat siswa tentang sudah tepatkah pendidikan kewirausahaan di ajarkan sejak dini sebanyak $26(89,65 \%)$ menjawab iya. Sebanyak $27(93,1 \%)$ siswa menyukai pembelajaran dengan pendekatan Scientific Sell. 23 (79,31\%) siswa menyukai kegiatan/ langkah menjual (Sell) dalam pendekatan Scientific Sell. Terakhir dapat diketahu bahwa $24(68,96 \%)$ anak berpendapat bahwa hasil karya nya laku terjual.

- Pada siklus I langkah-langkah pendekatan Scientific Sell adalah mengamati, menanya, mengumpulkan informasi, mengasosiasi, mencipta dan menjual. Selanjutnya pada siklus II langkah tersebut ditambah dengan siswa mengkomunikasikan/ merefleksikan kegiatan dari langkah-langkah sebelumnya. Dengan menggunakan 7 langkah dalam pendekatan Scientific Sell (mengamati, menanya, mengumpulkan informasi, mengasosiasi, mencipta, menjual dan mengkomunikasikan/ merefleksikan) dan dikukung oleh data nilai kognitif, afektif, psikomotor dan angket minat, dapat disimpulkan bahwa penelitian tindakan ini dihentikan sampai siklus II tanpa melanjutkan pada siklus III. Kekurangan yang belum dapat diselesaikan pada penelitian ini diharapkan dapat diatasi oleh peneliti lain.

\section{Temuan Penelitian}

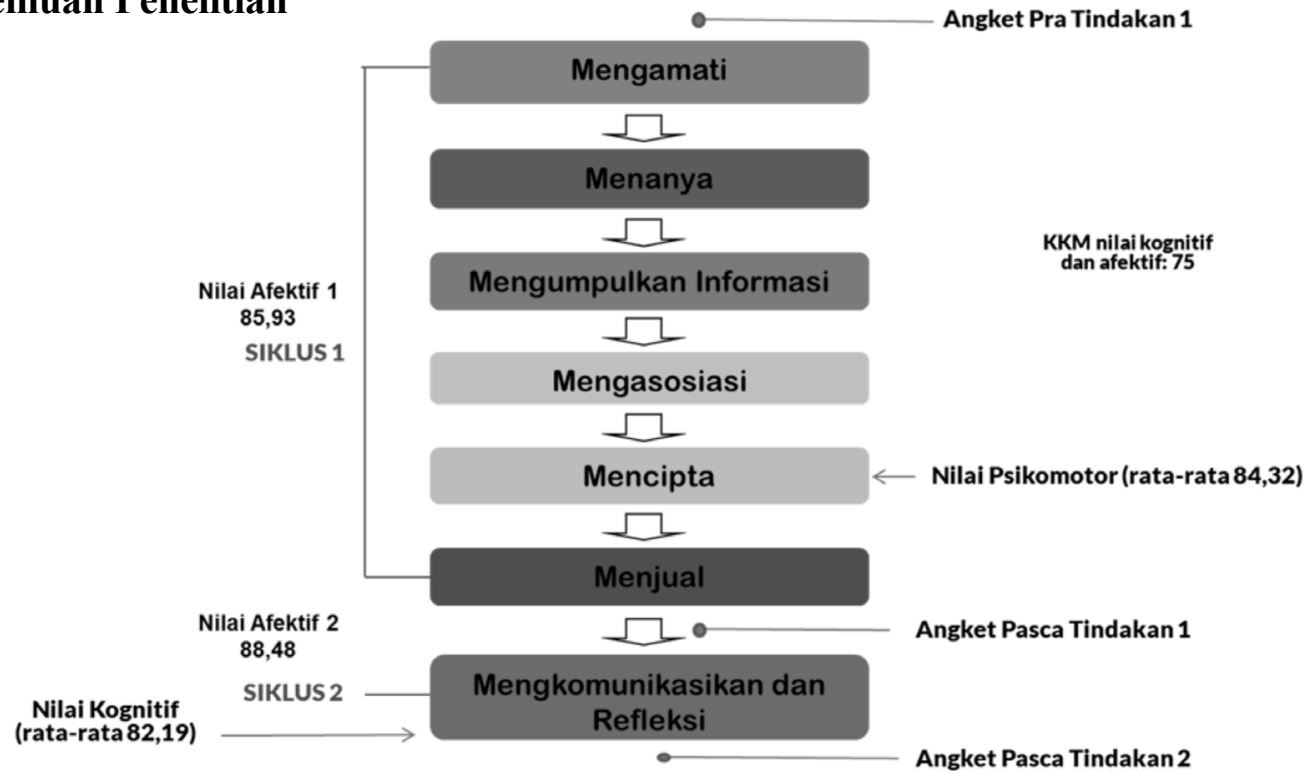

Skema 1. Sintaks penelitian pendekatan Scientific Sell

Sebagaimana hasil penelitian dengan sintaks seperti skema diatas maka temuan penelitian tentang keterlaksanaan
Pendekatan Scientific Sell untuk meningkatkan minat kewirausahaan siswa dalam Materi Melukis Ragam Hias pada 
Media Bangkiak secara maksimal adalah melalui langkah-langkah yang tepat, sebagai berikut:

a. Mengamati

Pada langkah mengamati, siswa melakukan pengamatan hasil karya seni kriya ragam hias flora, fauna dan geometrik yang ditunjukkan oleh guru melalui LCD dan memutarkan video tentang pembuatan bangkiak hias.

b. Menanya

Siswa mengumpulkan hasil pengamatannya tentang ragam hias dan bangkiak yang sudah di beri ragam hias. Dari kegiatan tersebut, akan memberikan stimulus para siswa untuk mengajukan beberapa pertanyaan tentang melukis ragam hias pada media bangkiak.

c. Mengumpulkan Informasi

Siswa berusaha menggali dan mengumpulkan informasi tentang ragam hias bangkiak dari berbagai sumber melalui berbagai cara. Salahsatunya melalui Search Engine (Google) dengan mencari gambar ragam hias dari berbagai daerah kemudian di print. Siswa juga mencari di berbagai sumber lain seperti baju Batik, majalah, buku, dll.

d. Mengasosiasi

Dari data-data yang sudah dikumpulkan oleh siswa tentang ragam hias dan bangkiak maka informasiinformasi baru akan masuk kedalam pikiran siswa dan mempengaruhinya. Selanjutnya informasi-informasi tersebut akan diolah didalam pikiran siswa sehingga akan membentuk suatu persepsi baru tentang pengaplikasian ragam hias pada media bangkiak.

e. Mencipta

Setelah menemukan keterkaitan antar informasi dan menemukan berbagai pola dari keterkaitan tersebut, selanjutnya secara bersama-sama dalam satu kesatuan kelompok, atau secara individual membuat kesimpulan dengan cara menuangkannya/mencipta menjadi sebuah karya ragam hias pada media bangkiak.

f. Menjual

Siswa harus berusaha menjual hasil karyanya kepada orang-orang di sekitarnya dengan menghitung terlebih dahulu biaya produksi dan menentukan laba sehingga keuntungan yang diperoleh lebih maksimal.

g. Mengkomunikasikan/refeksi.

Dalam langkah ini siswa diharapkan dapat mengkomunikasikan dan merefleksikan tentang apa yang telah mereka pelajari dan alami pada langkah-langkah sebelumnya. Kegiatan ini dilakukan dengan cara menjelaskan konsep dproduk, menjelaskan tampilan produk, menjelaskan inovasi produk, menjelaskan nilai tambah produk, serta menjelaskan tentang proses menjual.

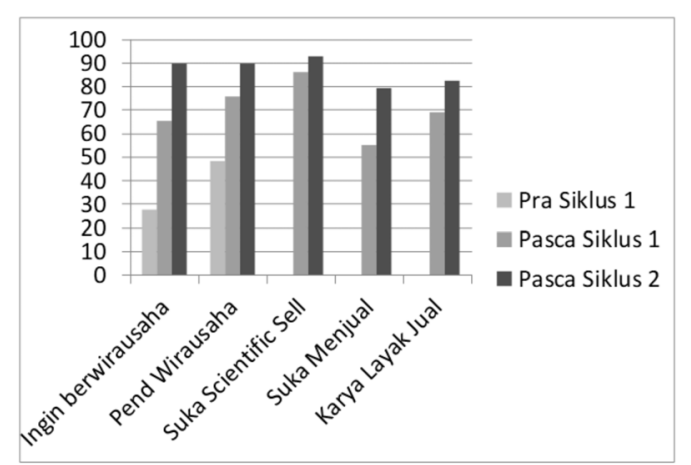

Grafik 1. Perbandingan hasil isian angket pra siklus I, pasca siklus I, dan pasca siklus II

Keterlaksanaan Pendekatan Scientific Sell dalam Materi Melukis Ragam Hias pada Media Bangkiak dalam Meningkatkan Minat Berwirausaha dapat dibuktikan melalui data berikut ini: 
Psikomotor

Dari hasil karya bangkiak yang dihasilkan siswa kelas 7.2 pada kompetensi dasar "membuat karya kriya kayu dengan memanfaatkan berbagai teknik dan corak" khususnya pada materi melukis ragam hias pada media bangkiak, rata rata nilai yang diperoleh adalah $84,32 \%$.

\section{Kognitif}

Dari hasil presentasi yang dilakukan siswa kelas 7.2 pada kompetensi dasar "membuat karya kriya kayu dengan memanfaatkan berbagai teknik dan corak" khususnya tentang proses pembelajaran melukis ragam hias pada media bangkiak dan menjualnya, rata rata nilai yang diperoleh adalah 82,19\%. Data selengkapnya ada pada hasil penilaian yang disajikan dalam Lampiran (Nilai Kognitif).

\section{Afektif}

Berdasarkan pengamatan minat siswa di siklus I pada pembelajaran melukis ragam hias dengan pendekatan Scientific Sell dapat diketahui bahwa minat siswa pada pembelajaran sebesar $85,93 \%$. Minat tersebut mengalami peningkatan sebesar $2,55 \%$ sehingga menjadi $88,48 \%$ pada siklus II.

Berdasarkan angket yang dibagikan ketika pembelajaran melukis ragam hias dengan pendekatan Scientific Sell berlangsung; terdapat $8(27,59 \%)$ siswa yang punya keinginan untuk berwirausaha dari pra tindakan siklus I, setelah tindakan pada siklus I meningkat menjadi 19 $(65,52 \%)$ siswa, dan meningkat lagi menjadi $26(89,65 \%)$ setelah mendapat tindakan pada siklus II. Untuk pendidikan kewirausahaan yang harus diajarkan sejak dini, pada saat pra tindakan siklus I terdapat $14(48,27 \%)$ siswa yang setuju dan meningkat menjadi $22(75,86 \%)$ siswa setelah dilakukan tindakan siklus I, setelah tindakan pada siklus II semakin meningkat menjadi $26(89,65 \%)$ siswa.

Setelah tindakan pada siklus I, 25 $(86,2 \%)$ siswa myatakan suka terhadap pembelajaran dengan pendekatan Scientific Sell dan semakin meningkat setelah dilakukan tindakan pada siklus II menjadi 27 (93,1\%) siswa. Kemudian sikap siswa terhadap langkah manjual (Sell) dalam pendekatan Scientific Sell setelah dilakukan tindakan pada siklus I terdapat $16(55,17 \%)$ siswa yang menyukai, dan menjadi 23 (79,31\%) siswa setelah tindakan siklus II. Pada siklus I, $20(68,96 \%)$ siswa mengatakan bahwa hasil karyanya layak untuk dijual, dan pada siklus II sebanyak 24 (68,96\%) siswa mengatakan bahwa hasil karya nya laku terjual.

\section{SIMPULAN}

Pendekatan Scientific Sell dalam materi melukis ragam hias pada media bangkiak, mampu meningkatkan minat siswa terhadap kewirausahaan siswa dengan menggunakan langkah; Mengamati, menanya, mengumpulkan informasi, mengasosiasi, mencipta, menjual dan Mengkomunikasikan/refeksi.

Keberhasilan pendekatan Scientific Sell dalam meningkatkan minat berwirausaha pada kelas 7.2, dapat dilihat dari rata-rata nilai psikomotor dalam berkarya yang mencapai $84,32 \%$. Ratarata nilai kognitif yang didapat dari hasil presentasi siswa sebesar $82,19 \%$, Sedangkan nilai afektif didapat berdasarkan pengamatan minat siswa di siklus I sebesar $85,93 \%$, dan mengalami peningkatan sebesar 2,55\% sehingga menjadi 88,48\% pada siklus II. Angket yang disebar pada pra dan pasca tindakan pada siklus I, maupun pasca tindakan pada siklus II menunjukkan peningkatan. 
Diharapkan kedepan pendekatan ini dapat diaplikasikan pada mata pelajaran yang lain dan kelas lain sehingga SMP Muhammadiyah 8 Batu dapat menjadi sekolah yang berbasis kewirausahaan dan menghasilkan lulusan yang mempunyai keahlian dan minat tinggi terhadap kewirausahaan

\section{DAFTAR PUSTAKA}

Alma, Buchari. 2004.Kewirausahaan Penuntun Perkuliahan untuk Perguruan Tinggi. Bandung: Alfabeta. Alma, Buchari. 2009. Manajemen Pemasaran dan Pemasaran Jasa. Bandung: Pustaka Setia.

Basrowi. 2016. Kewirausahaan Untuk Perguruan Tinggi. Bogor: Ghalia Indonesia.

Subandono, Aris. (2007). Pengaruh Life Skill Diklat Kimia Produktif dan Prestasi Belajar Diklat Kewirausahaan terhadap Minat Berwirausaha pada Siswa SMK Kimia Industri Theresiana Semarang. Skripsi tidak diterbitkan. Semarang: FMIPA Universitas Negeri Semarang.

http://swa.co.id/business-strategy/ management/jumlah-wirausahaindonesia-hanya-043-dari-totalpopulasi 


\section{INDEKS PENGARANG}

$\begin{array}{llll}\text { Agung Deddiliawan Ismail } & 560 & \text { Purwatiningsih } & 625 \\ \text { Ainur Rofieq } & 625 & \text { Rahmawati Khadijah Maro } & 609 \\ \text { Aninda Nidhommil Hima } & 588 & \text { Rizal Dian Azmi } & 560 \\ \text { Candra Dewi } & 567 & \text { Roimil Latifa } & 625 \\ \text { Djulikah } & 576 & \text { Roro Eko Susetyarini } & 625 \\ \text { Dwi Poedjiastutie } & 588 & \text { Sudiyono } & 639 \\ \text { Kharisma Naidi Warnanda S } & 588 & \text { Teguh Hadi Saputro } & 588 \\ \text { Laela Hikmah Nurbatra } & 609 & \text { Yuliati } & 649 \\ \text { Mariani } & 599 & \text { Zakki Fitroni } & 659 \\ \text { Nina Inayati } & 609 & & \end{array}$




\section{INDEKS SUBJEK}

B

Bilangan Berpangkat $\quad 639,640,641$, 642, 643, 644, 647

D

Drama

575

567, 568, 569, 570, $571,572,573,574$,

G

Geometer's Sketchpad

560, 561, $562,564,565$

Guided Questions System $\quad$ 649, 651, 656, 657, 658

I

Independent Study $\quad 609,610,611,612$, 614, 617, 618, $619,621,622$

Inside outside circle 567, 569, 571, 572, 574, 575

K

Ketahanan Pribadi $\quad$ 576, 577, 578, 579, 580, 582, 585, 586, 587

Keterampilan berbicara 567, 568,569, $570,571,572$, 573, 574, 575

Kewirausahaan 659, 661, 662, 664, 665, 666, 667, 669, 670

L

Lesson Study 625, 626, 627, 636, 637, 638

M

Make a Match 599, 601, 602, 603, 604, 605, 606, 607, 608
Mentoring 609, 610, 611, 612, 613, 614, $615,616,617,618,619,620$, $621,622,623,624$

Model Pembelajaran 567, 568, 569, 570, 571, 572, 574, 575, 599, 601, 602, 603, 604, 605, 606, 607, 608 Motivasi 649, 650, 651, 652, 653, 654, 655, 657, 658

$\mathrm{N}$

Need Analysis $\quad$ 588, 590, 596, 597

$P$

Pembelajaran Kooperatif $\quad 576,577$, 578, 579, 580, 581, 582, $583,584,585,586$

Praktik Kolaboratif $\quad 625,627,628$, 636,637

Problem Posing 639, 640, 641, 642, $643,644,645,647$

Project Base Learning $\quad 625,631,632$, 637

$\mathrm{S}$

Scientific Sell $\quad 659,660,661,662$, 664, 665, 666, 667, 668, 669, 670 Siklus $\quad 599,602,603,604$, $605,606,607$ STAD 576, 578, 580, 581, 582, 583, 584, 585, 586

$\mathrm{T}$

Think Pair Share $\quad$ 649, 650, 651, 652, 657,658

Trigonometri 560, 561, 562, 563, 564, 565 


\section{Petunjuk Penulisan Artikel JINoP (Jurnal Inovasi Pembelajaran)}

\section{Ketentuan Umum}

1. Yang dimaksud dengan "Naskah" dalam pedoman ini adalah artikel hasil penelitian tentang inovasi pembelajaran di semua bidang studi dan jenjang pendidikan mulai dari SD sampai Perguruan Tinggi.

2. Penulis naskah wajib membuat dan menandatangani surat pernyataan bermaterai yang menyatakan bahwa naskah yang ditulis merupakan hasil karya sendiri dan belum pernah dipublikasikan di media lain.

3. Naskah dapat di diunggah dan register lebih dulu melalui laman website : http://ejournal.umm.ac.id/index.php/jinop/user/register

\section{Ketentuan Penulisan Naskah}

1. Bahasa yang digunakan dalam penulisan naskah adalah Bahasa Indonesia atau Bahasa Inggris.

2. Naskah diketik di atas kertas A4 dengan margin kiri $4 \mathrm{~cm}$, margin atas, bawah dan kanan $3 \mathrm{~cm}$, menggunakan tipe huruf Times New Roman, ukuran huruf 12, dan spasi 1.

3. Jumlah halaman naskah adalah 10 sampai dengan 15 halaman.

4. Sistematika Penulisan:

a. JUDUL [Times New Roman 14 bold]

Penulisan judul menggunakan kalimat singkat, namun cukup untuk menggambarkan isi (substansi) naskah secara keseluruhan. Judul tulisan berbahasa Indonesia terdiri dari maksimal 14 kata, sedangkan apabila berbahasa Inggris terdiri dari maksimal 12 kata.

b. Nama Penulis [Times New Roman 12 bold]

Nama penulis dicantumkan tanpa gelar, kemudian disertai alamat korespondensi (instansi), dan alamat surat elektronik (email). Apabila terdapat lebih dari satu penulis maka dituliskan seperti penulis Utama. Untuk penulis utama harap menyertakan nomor HP yang bisa dihubungi.

c. ABSTRAK dan Kata Kunci [Times New Roman 10 bold]

Abstrak terdiri dari maksimal 200 kata. Abstrak mencerminkan permasalahan, tujuan, metode penelitian, hasil dan saran. Abstrak ditulis dalam Bahasa Indonesia dan Bahasa Inggris, menggunakan huruf jenis Times New Roman ukuran 10, spasi 1. Kata kunci disusun secara alfabetis, mencerminkan kandungan esensi artikel, dibuat sejumlah 3-5 kata/frase.

d. PENDAHULUAN [Times New Roman 12 bold]

Pendahuluan (berisi latar belakang, konteks penelitian, hasil kajian pustaka, dan tujuan penelitian, yang semuanya dipaparkan secara terintegrasi dalam bentuk paragraf-paragraf, dengan persentase 15-20\% dari keseluruhan artikel) Tinjauan pustaka yang relevan dan pengembangan hipotesis (jika ada) dimasukkan dalam bagian ini. [Times New Roman, 12, normal]. 
e. METODE [Times New Roman 12 bold]

Metode menjelaskan paparan dalam bentuk paragraf tentang rancangan penelitian, sumber data, teknik pengumpulan data, dan analisis data yang secara nyata dilakukan peneliti, dengan persentase 10-15\% [Times New Roman, 12, normal].

f. HASIL dan PEMBAHASAN [Times New Roman 12 bold]

Hasil penelitian berisi paparan hasil analisis yang berkaitan dengan pertanyaan penelitian, sedangkan pembahasan berisi pemaknaan hasil dan perbandingan dengan teori dan/atau hasil penelitian sejenis, dengan persentase 40-60\% dari keseluruhan artikel); Kemungkinan tindak lanjut kegiatan dapat juga disampaikan pada bagian ini Hasil penelitian dapat dilengkapi dengan tabel 1 (bukan tabel berikut: ), grafik/gambar 1 (bukan grafik/gambar berikut: ) , dan/atau bagan 1 (bukan bagan berikut: ). [Times New Roman, 12, normal].

Tabel 1. Nama Tabel (contoh tabel 1)

\begin{tabular}{lccc}
\hline & & \multicolumn{2}{c}{$95 \% \mathrm{CI}$} \\
\cline { 3 - 4 } Condition & $M(S D)$ & $\mathrm{LL}$ & $\mathrm{UL}$ \\
\hline Letters & $14.5(28.6)$ & 5.4 & 23.6 \\
Digits & $31.8(33.2)$ & 21.2 & 42.4 \\
\hline
\end{tabular}

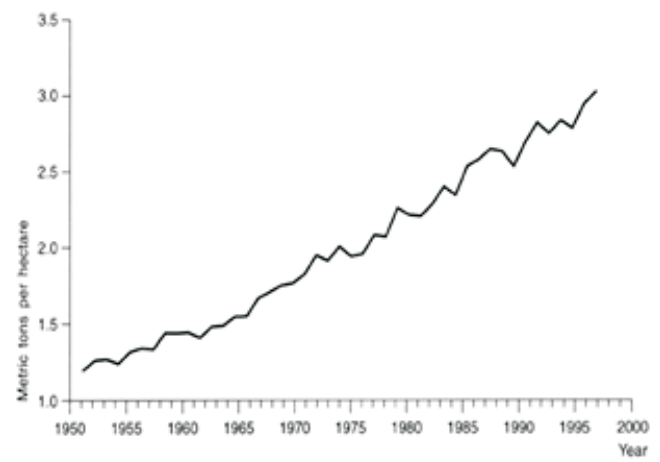

Gambar 1. Nama gambar (contoh gambar 1)

g. SIMPULAN [Times New Roman 12 bold]

Berisi temuan penelitian yang berupa jawaban atas pertanyaan penelitian atau berupa intisari hasil pembahasan, yang disajikan dalam bentuk paragraf. Saran dapat disampaikan pada bagian ini [Times New Roman, 12, normal].

h. Daftar Pustaka.

Daftar Pustaka ditulis dengan sistematika dan ditulis secara berurut sesuai abjad. Tanda baca koma diganti dengan tanda baca titik; tidak dicantumkan halaman kutipan; kutipan yang ada dalam batang tubuh (artikel) wajib dicantumkan di daftar pustaka begitu juga sebaliknya kutipan yang ada dalam daftar pustaka wajib ada di batang tubuh (artikel). 


\section{Rujukan Buku:}

Noddings, N. 1993. Educating for Intelligent Belief or Unbelief. New York: Teacher College Press.

Rujukan Artikel dalam Buku Kumpulan Artikel

Margono. 2008. Manajemen Jurnal Ilmiah. Dalam M.G Waseso \& A. Saukah (Eds.), Menerbitkan Jurnal Ilmiah (hlm. 46-50). Malang: UMM Press.

Rujukan Berupa Buku yang Ada Editornya

Rusli, Marah. 2005. Sosiologi Pendidikan: Kajian Berdasarkan Teori Integritas Mikro-Makro (Arnaldi. S Ed.) Malang: UMM Press.

Rujukan dari Buku yang Berasal dari Perpustakaan Elektronik

Dealey, C. 1998. The Care of Wounds: A Guide for Nurses. Oxford: Blackwell Science. Dari NetLibrary, (Online), (http://netlibrary.com), diakses 26 Agustus 2012.

Rujukan dari Artikel dalam Internet Berbasis Jurnal Tercetak

Mappiare-AT, A., Ibrahim, A.S. \& Sudjiono. 2009. Budaya Komunikasi RemajaPelajar di Tiga Kota Metropolitan Pantai Indonesia. Jurnal Ilmu Pendidikan, (Online), 16 (1): 12-21, (http://www.umm.ac.id) diakses 28 Oktober 2009

\section{Rujukan dari Artikel dalam Jurnal dari CD-ROM}

Krashen, S., Long, M. \& Scarcella, R. 2007. Age, Rate and Evantual Attainment in Second Language Acquisition. TESOL Quarterly, 13: 543-567 (CD-ROM: TESOL Quarterly-Digital, 2007).

Rujukan Artikel dalam Jurnal atau Majalah:

Wentzel, K. R. 1997. Student Motivation in Middle School: The Role of Perceived Pedagogical Caring. Journal of Educational Psychology, 89 (3), 411-419.

\section{Buku Terjemahan:}

Habermas , Jurgen. 2007. Teori Tindakan Komunikatif II: Kritik atas Rasio Fungsionaris. Terjemahan oleh Nurhadi. Yogyakarta: Kreasi Wacana.

Rujukan dari Dokumen Resmi Pemerintah yang diterbitkan oleh Lembaga tersebut

Undang-Undang Sistem Pendidikan Nasional (UURI No. 20 Tahun 2003 dan Peraturan Pelaksanaannya. 2003. Jakarta: Departemen Pendidikan Nasional.

\section{Rujukan dari Koran tanpa penulis}

Jawa Pos, 27 Mei 2015. “Komitmen Mendikbud Segarkan Pramuka”. Halaman 3.

Rujukan dari Internet:

Winingsih, H. Lucia. 2007. Peningkatan Mutu, Relevansi dan Daya Saing Pendidikan. Jakarta: Pusat Dokumentasi dan Informasi Ilmiah-Lembaga Ilmu Pengetahuan Indonesia PDII-LIPI, diakses 2 Desember 2014 on-line www. Pdii.lipi.go.id/ katalog/index. php/search catalog /byld/257453.

Rujukan Berupa Skripsi, Tesis, atau Disertasi.

Mulyana, Yoyo. 2000. Keefektifan Model Mengajar Respons Pembaca dalam Pengajaran Pengkajian Puisi. Disertasi tidak Diterbitkan. Bandung: Fakultas Fakultas Bahasa dan Seni Universitas Pendidikan Indonesia.

Musaffak. 2013. Peningkatan Kemampuan Membaca Kritis dengan Menggunakan Metode Mind Mapping. Tesis tidak Diterbitkan. Malang: PPs UM. 
5. Pustaka acuan yang digunakan adalah maksimal 10 tahun terakhir dengan jumlah minimal 10 buah dan minimal 50 \% diantaranya berasal dari jurnal ilmiah.

6. Redaktur berhak mengubah tulisan pada naskah sepanjang tidak mempengaruhi materi atau isi pokok pembahasan.

7. Segala sesuatu yang menyangkut perizinan pengutipan atau penggunaan software komputer untuk pembuatan naskah atau ihwal lain yang terkait dengan HaKI yang dilakukan oleh penulis artikel, berikut konsekuensi hukum yang mungkin timbul karenanya, menjadi tanggung jawab penuh penulis artikel. 


\title{
JUDUL DITULIS DENGAN FONT TIMES NEW ROMAN 14 CETAK TEBAL (MAKSIMUM 14 KATA)
}

\author{
Penulis1 $^{1)}$, Penulis2 ${ }^{2)}$ dst. [Font Times New Roman 12, tanpa gelar dan \\ Tidak Boleh Disingkat] \\ ${ }^{1}$ Nama Institusi (penulis 1, times new roman 11) \\ email: penulis_1@abc.ac.id (times new roman 11) \\ ${ }^{2}$ Nama Institusi (penulis 1, times new roman 11) \\ email: penulis_2@abc.ac.id (times new roman 11)

\begin{abstract}
ABSTRAK [Times New Roman 10, bahasa Indonesia]
Abstrak ditulis dalam bahasa indonesia berisikan tujuan penelitian, metode/pendekatan penelitian dan hasil penelitian. Abstrak ditulis dalam satu alenia, tidak lebih dari 200 kata. (Times New Roman 10, spasi tunggal).
\end{abstract}

Kata kunci: 3-5 kata kunci dipisahkan dengan tanda koma. [Font Times New Roman 10, spasi tunggal].

\section{ABSTRACT [Times New Roman 10, bahasa Inggris]}

Abstrak ditulis dalam bahasa Inggris yang berisikan tujuan penelitian, metode/ pendekatan penelitian dan hasil penelitian. Abstrak ditulis dalam satu alenia, tidak lebih dari 200 kata. (Times New Roman 10, spasi tunggal).

Keywords: 3-5 kata kunci dipisahkan dengan tanda koma. [Font Times New Roman 10, spasi tunggal]

\section{PENDAHULUAN [Times New Roman 12 bold]}

Pendahuluan (berisi latar belakang, konteks penelitian, hasil kajian pustaka, dan tujuan penelitian, yang semuanya dipaparkan secara terintegrasi dalam bentuk paragrafparagraf, dengan persentase 15-20\% dari keseluruhan artikel) Tinjauan pustaka yang relevan dan pengembangan hipotesis (jika ada) dimasukkan dalam bagian ini. [Times New Roman, 12, normal].

\section{METODE}

Metode menjelaskan paparan dalam bentuk paragraf tentang rancangan penelitian, sumber data, teknik pengumpulan data, dan analisis data yang secara nyata dilakukan peneliti, dengan persentase 10-15\% [Times New Roman, 12, normal].

\section{HASIL DAN PEMBAHASAN}

Hasil penelitian berisi paparan hasil analisis yang berkaitan dengan pertanyaan penelitian, sedangkan pembahasan berisi pemaknaan hasil dan perbandingan dengan teori dan/atau hasil penelitian sejenis, dengan persentase 40-60\% dari keseluruhan artikel); Kemungkinan tindak lanjut kegiatan dapat juga disampaikan pada bagian ini Hasil penelitian dapat dilengkapi dengan tabel 1 (bukan tabel berikut: ), grafik/gambar 1 (bukan grafik/gambar berikut: ), dan/atau bagan 1 (bukan bagan berikut: ). [Times New Roman, 12, normal]. 
Tabel 1. Nama Tabel (contoh tabel 1)

\begin{tabular}{lccc}
\hline & & \multicolumn{2}{c}{$95 \%$ CI } \\
\cline { 3 - 4 } Condition & $M(S D)$ & LL & UL \\
\hline Letters & $14.5(28.6)$ & 5.4 & 23.6 \\
Digits & $31.8(33.2)$ & 21.2 & 42.4 \\
\hline
\end{tabular}

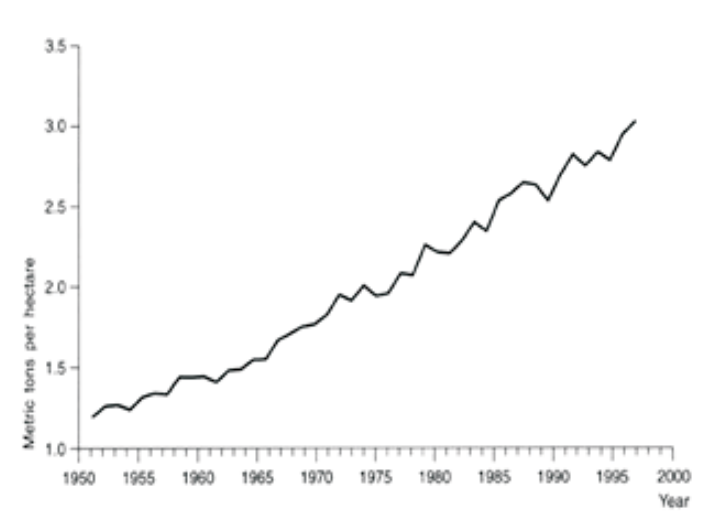

Gambar 1. Nama gambar (contoh gambar 1)

\section{SIMPULAN}

Berisi temuan penelitian yang berupa jawaban atas pertanyaan penelitian atau berupa intisari hasil pembahasan, yang disajikan dalam bentuk paragraf . Saran dapat disampaikan pada bagian ini [Times New Roman, 12, normal].

\section{DAFTAR PUSTAKA}

Penulisan pustaka hanya yang disitasi hanya dalam naskah ini dan diurutkan secara alfabetis dan kronologis.

\section{Buku:}

Gardner, H. 1993. Multiple Intelligences. New York: BasicBooks.

Buku kumpulan artikel:

Wahyono, P dan Sugiarti (Eds.). 2013. Pencerahan Pendidikan Masa Depan. Malang: UMM Press

Artikel dalam buku kumpulan artikel:

Bezooijen, R. V. 2002. Aesthetic evaluation of Dutch: Comparison across dialects, accents and languages. Dalam D. Long, \& D. R. Preston (Eds.), Handbook of perceptual dialectology (Vol. 2, hlm. 13-30). Amsterdam and Philadelphia: Benjamins.

\section{Artikel dalam jurnal atau majalah:}

Jaber, M., \& Hussein, R. 2011. Native speakers' perception of non-native English speech. English Language Teaching, 4(4), 77-87.

\section{Dokumen resmi:}

Undang-undang Republik Indonesia Nomor 2 tentang Sistem Pendidikan Nasional. 2003. Surabaya: Usaha Nasional 


\section{FORMULIR BERLANGGANAN JINoP (JURNAL INOVASI PEMBELAJARAN)}

Mohon dicatat sebagai pelanggan JINoP ( Jurnal Inovasi Pembelajaran)

Nama :

Status Pelanggan $\quad$ : lembaga/perorangan* (coret yang tidak sesuai)

Alamat

Sejumlah

Kode Pos

Telepon

Biaya sebesar Rp.

Eksemplar, setiap kali terbit, Mulai

Volume................, Nomor..... Tahun

melalui rekening a/n Ibu Sugiarti. Dengan nomor rekening 0388448086 BNI

Kantor Cabang Malang

*) Harga langganan : (a) Lembaga Rp 125.000,00 dan

(b) Perorangan Rp 100.000,00 per eksemplar

**) Ongkos kirim : a) Wilayah Jawa Rp 50.000,00;

b) Wilayah Luar Jawa Rp 100.000,00

Pelanggan 
